110 Nordic Council of Ministers

\title{
PVC WASTE TREATMENT IN THE NORDIC COUNTRIES
}

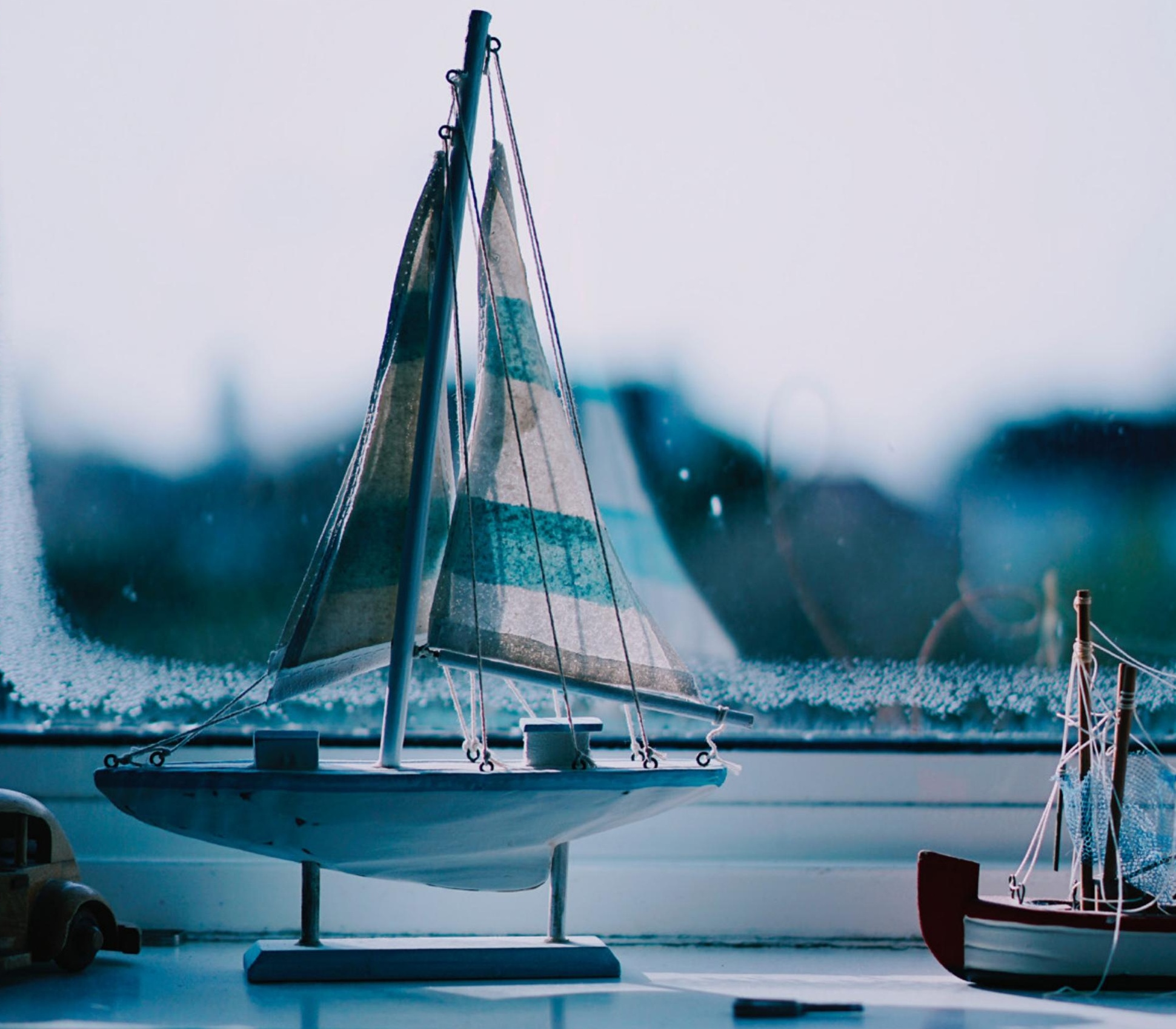





\section{PVC waste treatment in the Nordic countries}

Anna Fråne, Jurate Miliute-Plepiene, Alexandra Maria Almasi and Anna-Karin Westöö

TemaNord 2019:501 
PVC waste treatment in the Nordic countries

Anna Fråne (IVL Swedish Environmental Research Institute), Jurate Miliute-Plepiene (IVL Swedish Environmental Research Institute), Alexandra Maria Almasi (IVL Swedish Environmental Research Institute) and Anna-Karin Westöö (Statistics Sweden)

ISBN 978-92-893-5968-9 (PRINT)

ISBN 978-92-893-5969-6 (PDF)

ISBN 978-92-893-5970-2 (EPUB)

http://dx.doi.org/10.6027/TN2019-501

TemaNord 2019:501

ISSN 0908-6692

Standard: PDF/UA-1

ISO $14289-1$

(c) Nordic Council of Ministers 2018

Cover photo: Unsplash.com

\section{Disclaimer}

This publication was funded by the Nordic Council of Ministers. However, the content does not necessarily reflect the Nordic Council of Ministers' views, opinions, attitudes or recommendations.

Rights and permissions

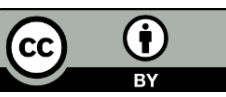

This work is made available under the Creative Commons Attribution 4.0 International license (CC BY 4.0) https://creativecommons.org/licenses/by/4.0

Translations: If you translate this work, please include the following disclaimer: This translation was not produced by the Nordic Council of Ministers and should not be construed as official. The Nordic Council of Ministers cannot be held responsible for the translation or any errors in it.

Adaptations: If you adapt this work, please include the following disclaimer along with the attribution: This is an adaptation of an original work by the Nordic Council of Ministers. Responsibility for the views and opinions expressed in the adaptation rests solely with its author(s). The views and opinions in this adaptation have not been approved by the Nordic Council of Ministers.

Third-party content: The Nordic Council of Ministers does not necessarily own every single part of this work. The Nordic Council of Ministers cannot, therefore, guarantee that the reuse of third-party content does not infringe the copyright of the third party. If you wish to reuse any third-party content, you bear the risks associated with any such rights violations. You are responsible for determining whether there is a need to obtain permission for the use of third-party content, and if so, for obtaining the relevant permission from the copyright holder. Examples of third-party content may include, but are not limited to, tables, figures or images. 
Photo rights (further permission required for reuse):

Any queries regarding rights and licences should be addressed to:

Nordic Council of Ministers/Publication Unit

Ved Stranden 18

DK-1061 Copenhagen K

Denmark

Phone +4533960200

pub@norden.org

\section{Nordic co-operation}

Nordic co-operation is one of the world's most extensive forms of regional collaboration, involving Denmark, Finland, Iceland, Norway, Sweden, and the Faroe Islands, Greenland and Åland.

Nordic co-operation has firm traditions in politics, economics and culture and plays an important role in European and international forums. The Nordic community strives for a strong Nordic Region in a strong Europe.

Nordic co-operation promotes regional interests and values in a global world. The values shared by the Nordic countries help make the region one of the most innovative and competitive in the world.

The Nordic Council of Ministers

Nordens Hus

Ved Stranden 18

DK-1061 Copenhagen K, Denmark

Tel.: +4533960200

www.norden.org

Download Nordic publications at www.norden.org/nordpub 



\section{Contents}

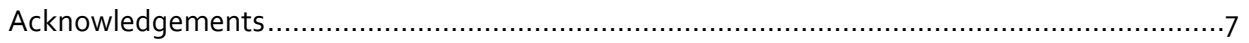

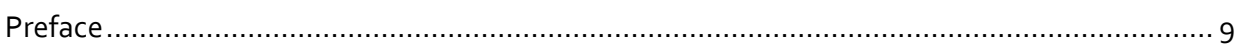

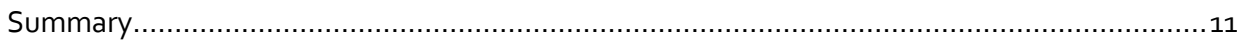

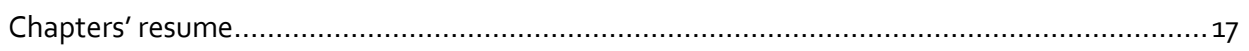

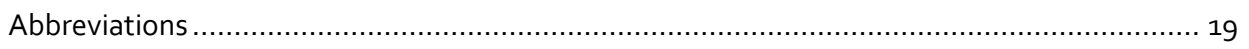

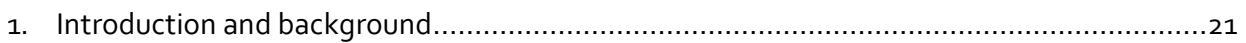

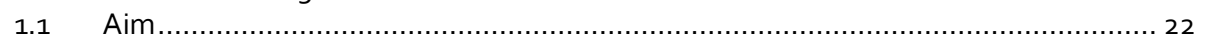

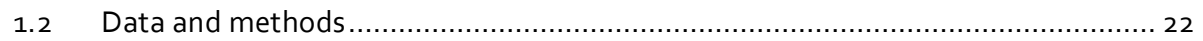

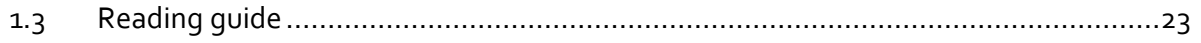

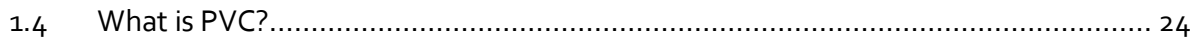

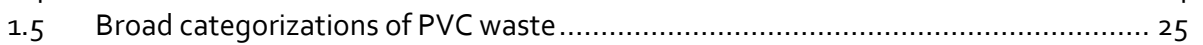

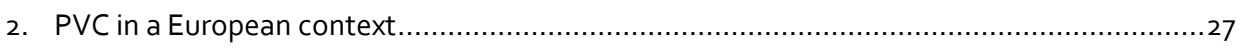

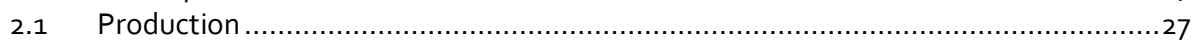

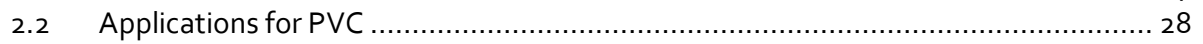

2.3 VinylPlus - the European PVC industry's voluntary commitment ...........................32

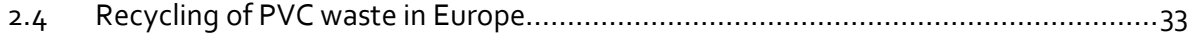

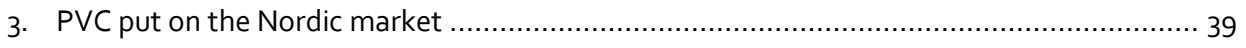

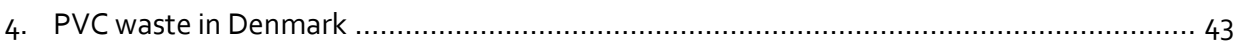

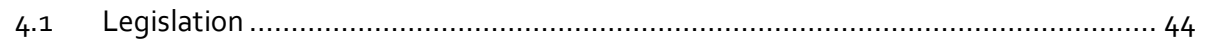

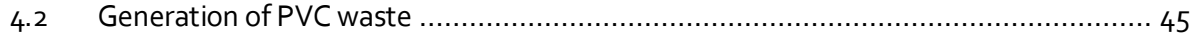

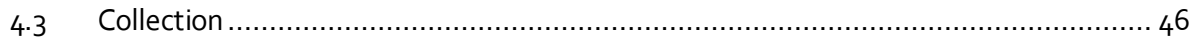

$4.4 \quad$ Treatment of PVC waste ............................................................................. 51

4.5 Summary of PVC waste generation, collection and treatment in Denmark ............ 52

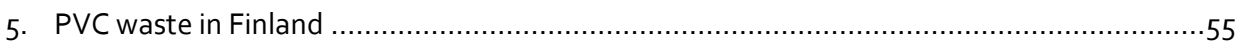

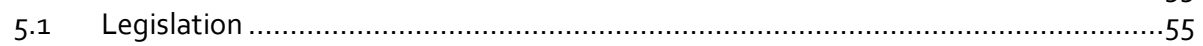

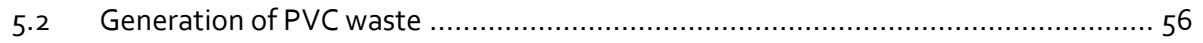

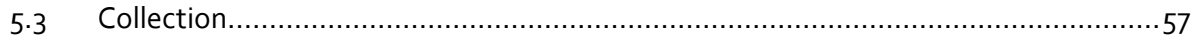

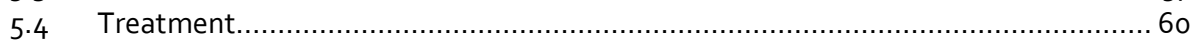

5.5 Summary of PVC waste generation, collection and treatment in Finland ...............62

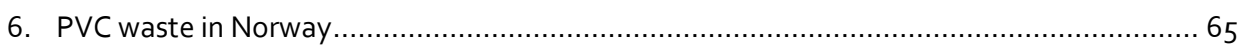

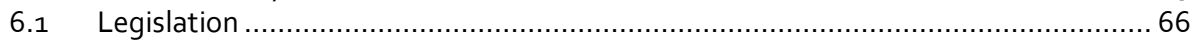

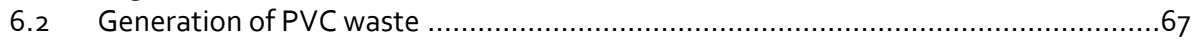

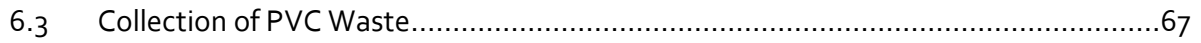

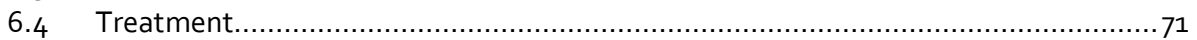

6.5 Summary of PVC waste generation, collection and treatment in Norway.................72

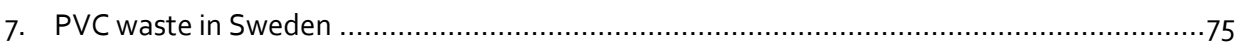

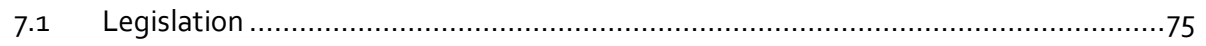

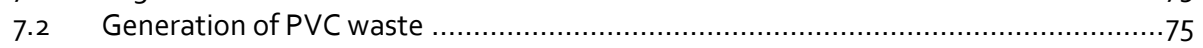

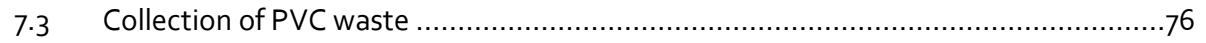

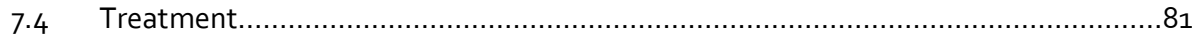

7.5 Summary of PVC waste generation, collection and treatment in Sweden ............... 84

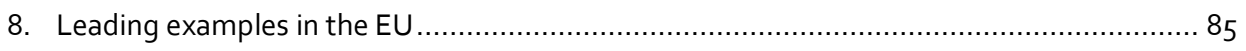

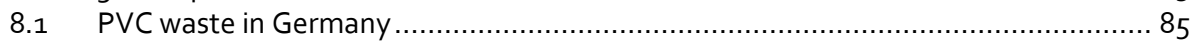

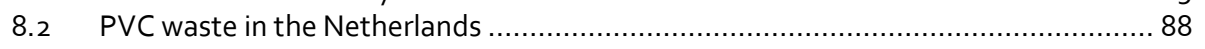

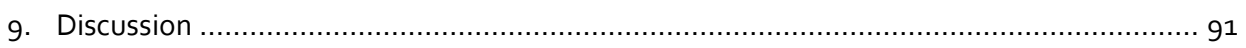


10. Conclusions.

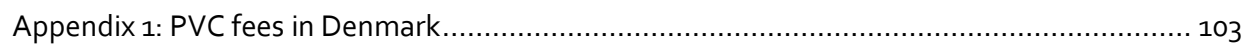

Appendix 2: Statistics - exports, imports and production of goods ................................ 105

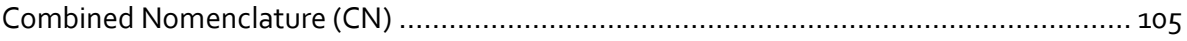

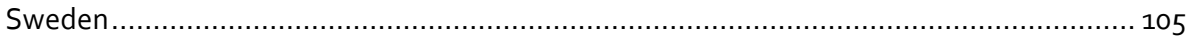

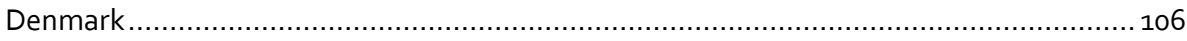

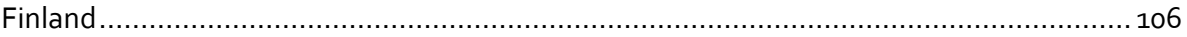

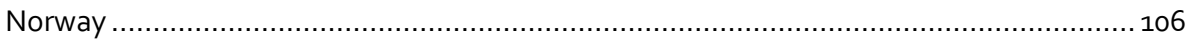

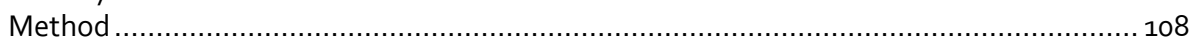




\section{Acknowledgements}

The project group expresses the gratitude to everyone involved in the study for their time and input. This includes all interviewees and experts in the four Nordic countries and outside.
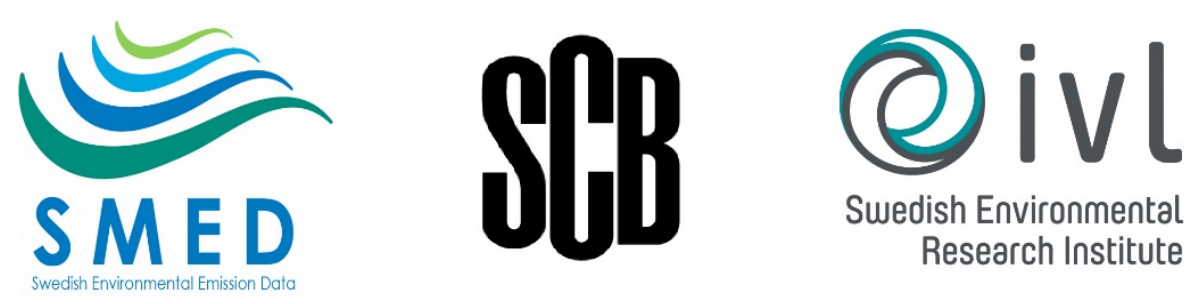

Swedish Environmental Research Institute 


\section{Preface}

The aim of the project was to map PVC waste streams in Denmark, Sweden, Norway and Finland and to explore the reasons behind the current conditions. An overview of PVC waste management in all Nordic countries yields a rather fragmented picture. There are no systematic statistics on the total generation of PVC waste in neither of the Nordic countries. The available estimates are made occasionally, mostly within the frames of different projects and are not based on any formalized official reporting system or other rigorous accounting scheme. Only Denmark collects official statistics specifically on the amounts of separately collected and treated PVC waste materials. The PVC waste management situation in Denmark is slightly different than in the other Nordic countries, where a nation-wide dedicated collection system for PVC waste exists. Denmark also has a long history of a national collection system for rigid PVC waste from the construction and demolition sector, which was established by producers and importers of PVC products. In the other Nordic countries several separate collection systems for pre-consumer PVC waste (mainly business-to-business) exist, initiated by businesses producing/importing flooring and piping products. The amounts of PVC waste collected within these collection systems are uncertain, but are most likely minor. For all studied countries most of the recycling of clean pre-consumer PVC waste takes place abroad. Overall, a large part of PVC waste in Finland, Norway, Sweden and, to a smaller extent, in Denmark ends up in mixed waste fractions and is eventually treated in wasteto-energy plants. Landfilling of PVC waste is banned in two countries (Sweden and Finland), but some exceptions exist. In Norway it is legal to landfill PVC waste, but landfilling is usually a more expensive option. Norway is the only country that treats some PVC waste from the construction and demolition industry as hazardous waste. Denmark is the country where soft PVC waste is legal to landfill. The current waste treatment situation in the four Nordic countries is driven by several factors. The main issues of the still underexplored potential environmental impact of PVC waste relate to diverse origins of PVC products, some specifics of the Nordic market, rather low focus on PVC waste in policy strategies or plans, technical issues regarding incineration of PVC waste, and the lack of domestic recycling capacities. 


\section{Summary}

Keywords: Polyvinyl chloride, PVC, PVC waste, plastic, waste management, Nordic, Sweden, Denmark, Norway, Finland.

Polyvinyl chloride (PVC), due to its long lifespan and many good mechanical, electrical, chemical, thermal and fire resistance properties, has become the third most used plastic in Europe. However, achieving the desired properties requires adding different additives, some of which contain hazardous substances that pose different environmental and health risks. Due to the broad use of PVCs in the society, its waste is likely to be present in many waste streams and subjected to diverse end-of-life treatments. The aim of the project was to map PVC waste streams in Denmark, Sweden, Norway and Finland and explore the reasons behind the current conditions. The key results and main findings are presented below.

\section{PVC put on the market}

Due to lack of production data for some countries in official statistics, it was not possible to retrieve reliable data about PVC and PVC goods put on the market.

\section{Generation of PVC waste in the Nordic countries}

The current overview of PVC waste management in all Nordic countries resulted in a rather fragmented picture based primarily on expert interviews. There are no systematic statistics on the total generation of PVC waste in neither of the Nordic countries. The available estimates are irregular and often part of different projects or studies with diverse objectives. In neither of the Nordic countries except Denmark are there any formalized official reporting systems or other rigorous accounting schemes.

Estimates on PVC waste generation in Norway, Finland and Sweden are mainly based on old reports, experts' evaluations or extrapolations from average European data. The regional average per capita of PVC generation is in the range of $5-5.5 \mathrm{~kg} / \mathrm{cap}$ ita. However, this estimate should be used with caution. For instance, the most recent data from a report of the Danish EPA (in press) estimated annual total national PVC waste generation rates at $30 \mathrm{kt}$ for soft and $36 \mathrm{kt}$ for rigid PVC (i.e. $66 \mathrm{kt}$ total). This corresponds to $11 \mathrm{~kg}$ per capita, which is twice the average regional estimate. 


\section{General management of PVC waste in the Nordic countries}

Denmark is the only country in the Nordic region that maintains statistics on how the separately collected PVC waste is treated. For instance, in 2017, 7,000 tonnes were collected separately, 6,825 tonnes (97.5\%) were sent to recycling, 169 tonnes (2.4\%) to landfilling, and 4 tonnes to energy recover. Most of the recycling for the separately collected PVC waste takes place abroad. Taking the estimate of annual total PVC waste generation (circa $66 \mathrm{kt}$ ) recycling covers only circa $10 \%$ of this amount. However, the total estimate is not reliable due to poor data accuracy on the PVC share in mixed waste and other separately collected waste streams.

The other Nordic countries have no reliable data in their official statistics on how PVC waste treatment is distributed between recycling, energy recovery and landfilling. Characteristic to all countries is that a large amount of PVC enters mixed waste flows or is collected together with other separately collected waste streams, where it is not the target material.

According to our study indicative PVC treatment tendencies could be outlined for some waste streams.

\section{PVC in C\&D waste}

Denmark has a history of a nationwide collection system for rigid PVC waste from the construction and demolition sector. It was established by producers and importers of PVC products. In 2017, circa 2,000 tonnes were collected within the system. Nationwide separate collection at municipal recycling centres also exists only in Denmark. In the other Nordic countries several separate collection systems for pre-consumer PVC waste exist initiated by business producing/importing flooring and piping products, although it mostly is business-to-business. The amounts of PVC waste collected in these collection systems are uncertain.

PVC waste from demolition and renovation, mainly PVC flooring, is collected as hazardous waste in Norway. In 2017, 4,500 tonnes of waste containing phthalates was reported to the Norwegian EPA, most of that amount is assessed to be soft PVC flooring.

PVC that ends up in other separately collected waste streams such as ELVs, health care, WEEE, cables and packaging in the Nordic countries are usually treated rather similarly.

\section{PVC in ELV waste}

Some larger parts of PVC waste in ELVs are dismantled and stored (in Finland), but much of this PVC material ends up as shredding light fraction (SLF). SLF usually goes to energy recovery (in Sweden, Finland, Denmark and Norway) or landfilling (Denmark, Norway). Some SLF in Norway may be sent for recycling. The project group 
estimated that $1-5 \mathrm{kt}$ of PVC may theoretically be present in the SLF fraction (1-2 kt in Finland, 2-3 kt in Denmark, 3-5 kt in Sweden and circa 3 kt in Norway).

\section{PVC in healthcare waste}

To our knowledge, PVC from health care are not recycled in neither of the Nordic countries. It is collected either separately as hazardous waste or enters mixed waste streams. In both cases this PVC ends up in energy recovery.

\section{PVC in cables and WEEE}

In the Nordic countries PVC in cables is not a targeted material and usually goes to granulation and later to energy recovery or landfilling, but shares are largely unknown and estimates are not reliable. In Sweden, the recycling of PVC waste from cables is not specifically targeted and most of it is sent to energy recovery or storing (not landfilling). The presence of PVC material in WEEE is rather small.

\section{PVC in packaging}

PVC in packaging in Norway, Sweden and Denmark may be collected within national EPR packaging systems and is generally sorted as a reject fraction and later sent to energy recovery. In Finland PVC in packaging is not accepted by its EPR system and is most likely going into mixed waste flow and ends up in energy recovery.

\section{General treatment of PVC waste}

In all Nordic countries the recycling of clean pre-consumer PVC waste (mainly from the construction sector) takes place abroad. Exceptions are some smaller on-site recycling capacities for clean pre-consumer PVC waste, but there is no reliable information about the recycled amounts. Regardless, according to our estimates, the amounts of recycled PVC waste in the Nordic region are still minor. The bulk of PVC waste in Finland, Norway, Sweden and, to a slightly smaller extent, in Denmark ends up in mixed waste streams and is eventually treated in waste-to-energy plants. Landfilling of PVC waste is banned in Sweden and Finland, but some exceptions exist. In Norway it is legal to landfill PVC waste, but it is usually a more expensive option. Norway is the only country that treats some PVC waste from the construction and demolition industry as hazardous waste. Denmark is the only country where landfilling of soft separately collected PVC waste is legal. Accurate data on the distribution between incineration and landfilling is not available, but landfilling is marginal in all Nordic countries. 


\section{Reasons for current status and future plans}

The current waste treatment situation is driven by several factors that inhibit economies of scale and higher rates of collection and recycling of PVC waste. One aspect is that PVC is dispersed in many different product groups, which are handled by different collection systems. Another aspect is the specifics of the Nordic market: geographically dispersed regions, low populated areas and low consumption of some highly recyclable products (e.g. PVC window frames). Thus, PVC waste collection is not a major business for many private companies.

None of the Nordic countries, except for Denmark, have a specific focus on strategies or legislation for PVC waste issues. Compared to other Nordic countries, in Denmark PVC has attracted more political debate since the 1990 s concerning incineration of PVC waste and hazardous substances in PVC materials. The political debates facilitated supporting legislation for a nationwide collection system for rigid and soft PVC waste through manned central collection sites. Different industry initiatives and the participation of producers and importers in systems such as VinylPlus, resulted in a nationwide separate collection of rigid PVC materials from the construction sector. The system is financed by producers, which also receive some financial support from VinylPlus.

Landfill bans of organic and combustible waste (in Finland and Sweden) and high costs for landfilling were among the main reasons for less PVC going to landfilling and most being incinerated with energy recovery. Denmark is the only country were landfilling of soft PVC is legal, but even here landfilling is minor. The largest share of PVC enters incineration through mixed waste streams. Sometimes this contributes to some technical concerns, such as corrosion of the flue gas cleaning systems in wasteto-energy plants. To prevent chlorine compounds in flue gases, specific legal requirements are set for minimum incineration temperature (minimum1,000 ${ }^{\circ} \mathrm{C}$ ). Lack of domestic recycling capacities results in some exemptions from the landfilling bans in Sweden and Finland. In the latter there seems to be a growing political interest in finding better solutions for the management of PVC waste.

In Denmark, a national strategy for circular economy was recently published, where PVC is mentioned in the political agreement on common strategy/actions within the chemical area, where DKK 4 million are dedicated to actions regarding hazardous substances in PVC and substitution to other material types. As the first step towards this plan, a study on "Mapping of PVC in Denmark" is pending publication, which results will be used to define the need for further studies to define a new Danish PVC strategy. PVC has also a special focus in the Chemical Action Plan (2018-2021). According to our interviews, in other Nordic countries there does not seem to be any other particular plans to change the situation of PVC waste management. On 1 November 2018 one of the largest PVC pipe recycling companies, Van Warven, will start business in Borås (Sweden) where it will establish a manual sorting line for PVC plastic waste to be sent to the Netherlands for recycling. 


\section{Overview of Germany and the Netherlands}

Germany is among the leading countries in PVC waste recycling, reaching 37\% of recycling for PVC in post-consumers waste. At this recycling level, in 2013 it already achieved one third of the 2020 recycling target for the European PVC industry set by the VinylPlus initiative. The main constituent of separately collected PVC waste is window frames and other PVC profiles. Other PVC waste materials end up in mixed waste flows and go to energy recovery.

The Netherlands also recycle significant amounts of its PVC waste, which are mainly PVC pipes. Both countries have large PVC manufacturing and recycling companies, which are a part of the VinylPlus initiative. Together with other actors within PVC value chains they are organising separate collection of PVC materials. 


\section{Chapters' resume}

The report consists of 10 chapters:

- Chapter 1. Introduction \& background. The chapter presents the aim of the project and provide background information regarding PVC waste streams in the four Nordic countries.

The aim of the project was to map PVC waste streams in Denmark, Sweden, Norway and Finland and to identify the underlying reasons behind the current state of management of waste PVC. The chapter presents the results of a literature review and interviews with experts, which were the main methods for data collection.

- Chapter 2. PVC in the European context. The chapter presents the current situation of PVC waste management in Europe.

Currently Europe (EU 28) produced ca. 5.5 million tonnes of PVC waste annually, which makes PVC among the third most used plastics on the continent. PVC is used in a variety of applications. The four largest sources of PVC waste generation include: construction sector, electric and electronic equipment, vehicles, health care products and packaging. VinylPlus is an important European industrial initiative consisting of PVC manufacturers, additive producers and converters, and is dedicated to PVC waste collection and recycling. Currently the initiative implements its ten-year voluntary commitment regarding the recycling of $900 \mathrm{k}$ tonnes of PVC by 2025 and at least 1,000 k-tonnes by 2030.

- Chapter 3. PVC materials and PVC-containing products on the Nordic market. The chapter presents information on the amounts and origins of PVC waste on the Nordic market.

Due to lack of production data for some countries in official statistics, it was not possible to retrieve reliable data about PVC and PVC goods put on the market.

- Chapters 4-7. PVC waste in the Nordic countries. The chapter presents the situation regarding PVC waste generation, collection and treatment in Denmark, Finland, Norway and Sweden.

The regional average of PVC waste generation is circa $5-5.5 \mathrm{~kg} / \mathrm{capita}$. This estimate should be used with caution as it relies mainly on expert estimates or old reports and are in a much lower range than the most recent Danish report (11 $\mathrm{kg} / \mathrm{capita}$ ). The available different data sources on PVC waste management in all Nordic countries provide a rather inconsistent message. This is largely attributed to the lack of harmonised and standardised statistics and the diversity of PVC management systems and organisations. Overall, a large part of PVC waste in Finland, Norway, Sweden and, to a smaller extent, in Denmark ends up in mixed 
waste fractions and is eventually treated in waste-to-energy plants. Landfilling of

PVC waste is banned in two countries (Sweden and Finland), but some exceptions exist. In Norway it is legal to landfill PVC waste, but landfilling is usually a more expensive option. Norway is the only country that treats some PVC waste from the construction and demolition sector as hazardous waste. Denmark is the country where landfilling of soft PVC waste is legal.

- Chapter 8. Leading examples in the EU. The chapter presents an overview of PVC waste in Germany and the Netherlands as the leading countries in PVC recycling in the EU.

These countries have large PVC manufacturing and recycling companies, which are a part of the VinylPlus initiative. They together with other actors within PVC value chains organise rather effective schemes for separate collection of PVC materials.

- Chapter 9-10. Discussion \& Conclusions. The chapter discusses why there is only rather fragmented information on the status of PVC waste management in the Nordic region.

A significant share of PVC waste in the region still ends up in mixed waste fractions which eventually are treated in waste-to-energy plants. The main issues that relate to still underexplored potential environmental impact of PVC waste relate to diverse origins of PVC products, some specific of the Nordic market, rather low focus on PVC waste in policy strategies or plans, technical issues regarding incineration of mono-streams of PVC waste, and the lack of domestic recycling capacities.

- Appendices provide PVC fees for different products comprised of flexible PVC in Denmark as well as trade statistics (exports and imports of PVC goods). 


\section{Abbreviations}

$\begin{array}{ll}\text { SLF } & \text { Shredder Light Fraction } \\ \text { WEEE } & \text { Waste Electrical and Electronic Equipment } \\ \text { ELVs } & \text { End of Life Vehicles } \\ \text { MSW } & \text { Mixed Solid Waste } \\ \text { SCB } & \text { Statistics Sweden } \\ \text { ABS } & \text { Acrylonitrile Butadiene Styrene Acrylonitrile } \\ \text { SAN } & \text { Styrene Acrylonitrile } \\ \text { PC } & \text { Polycarbonate } \\ \text { PP } & \text { Polypropylene } \\ \text { HIPS } & \text { High Impact Polystyrene } \\ \text { EWC } & \text { European Waste Catalogue }\end{array}$




\section{Introduction and background}

Modern society is probably impossible to imagine without plastics. For the past 60-80 years the use of plastics has been growing exponentially. Plastics substituted many traditional materials and enabled new products with better properties and superior performance characteristics. At the same time society is becoming increasingly concerned with the environmental impacts associated with the production, use and disposal of plastics. Closing material loops through different reuse and recycling approaches could address some of the problems.

Polyvinyl chloride (PVC), thanks to its long lifespan and many good mechanical, electrical, chemical, thermal and fire resistance properties, has become one of the most used polymers in the world. However, achieving the desired properties requires adding different additives, such as stabilizers, colorants, and plasticizers. Some additives contain hazardous substances, which pose different environmental and health risks. Hazardous substances previously used in PVC can still be present in PVC waste.

PVC has been used in many industrial and household products with long lifespans, for instance, building and construction materials, automobiles, piping and cable isolation. Due to PVC's broad usage in the society, PVC waste is likely to be present in many different waste streams and subjected to various end-of-life treatments.

On behalf of the Nordic Waste Group (Nordiska avfallsgruppen-NAG), SMED (Svenska MiljöEmissionsdata) received the task of mapping out how PCV waste is collected and managed in the Nordic countries. In earlier assignments, submitted by the Swedish Environmental Protection Agency to the Ministry of the Environment and Energy, various hazardous substances present in different waste streams have been studied. It was found that PVC waste is handled differently in different Nordic countries. By developing a better understanding of how PVC is managed and why, the environmental authorities in each Nordic country should be able to better assess whether the treatment of PVC waste needs to change. The project also relates to target 4 and target 16 of the Nordic programme to reduce the environmental impact of plastic. ${ }^{1}$

\footnotetext{
${ }^{1}$ https://norden.diva-portal.org/smash/get/diva 2:1143447/FULLTEXTo1.pdf
} 


\subsection{Aim}

The aim of the project is to map how PVC waste is managed in Denmark, Sweden, Norway and Finland. The overarching questions of interest are the following:

- How is PVC waste from different sources being handled in the Nordic countries (from collection to recycling, energy recovery, and landfilling)?

- What are the main reasons/motives for how PVC waste is treated in the Nordic countries (e.g. infrastructure, national regulatory framework, interpretation of EU legislation, etc.)?

- Are there any specific plans to change how PVC waste is managed in the Nordic countries?

- What are the approximate amounts of PVC waste generated annually in the Nordic countries and how are these amounts distributed among recycling, energy recovery and landfilling?

- How is PVC waste handled in Germany and the Netherlands (general overview)?

\subsection{Data and methods}

Information for this study was collected through literature and interviews with experts. Both methods were used simultaneously as the interviewed experts often referred to specific secondary data sources (e.g. databases or reports).

For each country the project developed lists of experts based on inputs from the Nordic Waste group.

A uniform topical questionnaire was prepared for the interviews in all countries to make sure that the same aspects were covered. The project employed a largely qualitative interview approach, but where feasible, the interviewees were also asked for factual data to corroborate qualitative answers. Although each topical area had a set of fixed questions, the project allowed for more flexible question formulations to adapt to the qualitative nature of information and the interviewees' ways to reason and express themselves.

The project has also explored statistical information on exports/imports of PVC and PVC waste available from the official offices in Sweden, Norway, Denmark and Finland including the Finnish customs office. Appendix 2 presents the methodology for data on trade statistics.

Some estimates required assumptions. For example, to assess the amount of PVC material present in ELVs, the project consulted experts ${ }^{2}$ who estimated that $2-3 \%$ of the shredded vehicles consist of PVC material. The project then referred to the official national statistics for each country regarding the number of ELVs sent to shredding and

\footnotetext{
${ }^{2}$ Cullbrand, K (2018). Personal communication with Klas Cullbrand, Chalmers Industriteknik.
} 
assumed the average weight of an ELV 3 at $800-900 \mathrm{~kg}$. This resulted in the projects' estimate of the total amount of PVC in shredder light fraction (SLF) from ELVs.

\subsubsection{Limitations}

Overall it was not always possible to find experts who possessed a clear and comprehensive picture of PVC waste management in individual countries. A snow-bowling approach was employed (asking interviewing person to indicate another relevant person) to increase the interview pool. Therefore, the initial number of 6 experts per country became greater. Another limitation was a smaller than expected response rate. For instance, in Finland the project group sent 38 interview invitations and only 9 experts agreed to be interviewed or to send some answers by email. Similarly, in Norway, circa 30 persons were contacted, but the majority was able to provide only very narrow information on the topic. One of the main reasons is that specific expertise regarding PVC is rather limited in all countries.

Secondary information sources were rather scarce. Data on waste composition and presence of PVC were either poor, not available or outdated in many countries. Information on PVC waste management in Finland was primarily based on expert interviews, since literature sources were scarce, largely outdated (e.g. from 2000) or available only in the Finnish language for which the project did not have sufficient resources.

The information gathered for the Netherlands was mainly based on an older report from 2011 and one PVC recycler interview.

\subsection{Reading guide}

This report consists of 10 main sections:

- Section 2-PVC in a European context. In this section PVC production in Europe, main PVC applications in different sectors, management activities, main recycling methods and dominant practices and some voluntary agreement programs by the industry, such as VinylPlus are briefly described.

- Section 3-PVC put on the Nordic market - provides a short description of PVC and PVC products put annually on the market and production activities in the Nordic countries.

- Section 4 - PVC waste in Denmark - describes PVC waste generation, collection and treatment activities in Denmark.

- Section 5-PVC waste in Finland - describes PVC waste generation, collection and treatment activities in Finland.

\footnotetext{
${ }^{3}$ Assuming that an average ELV to shredding weights $800-900 \mathrm{~kg}$. Abraham, M (2018). Personal communication with Mi-
} chael Abraham, Sveriges Bilåtervinnares Riksförbund. In Norway, country-specific average of 1,088 kg was used. 
- Section 6 - PVC waste in Norway describes PVC waste generation, collection and treatment activities in Norway.

- Section 7-PVC waste in Sweden - describes PVC waste generation, collection and treatment activities in Sweden.

- Section 8-Leading examples in the EU - provides a short information on PVC waste systems in Germany and the Netherlands.

- Section 9-Discussion - summarizes the results and provides main issues related to PVC waste collection and management in the Nordic countries.

Section 10 - Conclusions

- Appendices - provide PVC fees for different products comprised of flexible PVC in Denmark as well as trade statistics (exports and imports of PVC goods).

\subsection{What is PVC?}

PVC is the third most used polymer in the world. The PVC resin is produced from fossil oil and salt. Through chemical processes the salt is separated into sodium and chloride, and the oil into ethylene. PVC resin constitutes $57 \%$ of chlorine and $43 \%$ of salt. Ethylene and chlorine react into ethylene dichloride. Ethylene dichloride is turned into the monomer vinyl chloride under high temperature and pressure. There are several polymerization processes to convert vinyl chloride to polyvinylchloride. Different polymerization processes generate different types of PVC. The finished polyvinylchloride (PVC) is delivered as a white powder to further processing. The production of PVC resin can be summarized in the following steps: 4

1. Cracking of oil or gas generates ethylene;

2. Chlorine is produced from electrolysis of sodium chloride (salt);

3. Catalysation of ethylene and chloride generates ethylene dichloride;

4. Pyrolysis of ethylene dichloride makes vinyl chloride;

5. Polymerization of vinyl chloride produces polyvinylchloride (PVC).

The PVC resin as a powder is not enough to make PVC products. First, the PVC needs to go through compounding. In the compounding step different additives are added to the PVC resin depending on wanted properties. In Table 1, common types of additives and their function are described. ${ }^{5}$

4 PVC Informationsrådet (2018). https://pvc.dk/om-pvc/hvordan-fremstilles-pvc/

${ }^{5}$ European Commission (2000). The behaviour of PVC in landfill. 
Table 1: Common types of additives and their function in PVC

\section{Additives $\quad$ Property of PVC article affected}

Stabilizer

Colorant Colour

Plasticizer

Impact modifier

Lubricants

Fillers

Flame retardants

Antistatic agents

Blowing agents
Prevents decomposition during processing, imparts light and weather resistance Colour, weather resistance

Mechanical properties, burning behavior

Impact strength and other mechanical properties

Rheology of the PVC melt, transparency, gloss, surface finish and printability

Electrical and mechanical properties

Burning behavior

Electrical properties

Processing to expanded products

The PVC compound is bought by actors who extrude, mold the compound into various shapes. The PVC products are purchased by manufacturers that make final goods for the consumer market.

\subsection{Broad categorizations of PVC waste}

PVC waste could be classified into pre- and post-consumer waste categories. The postconsumer waste consists of discarded end-of-life products or parts of products containing PVC material (e.g. waste packaging, used pipes, used windows etc.). ${ }^{6}$

The pre-consumer waste is generated either during the installation of PVC products (e.g. when PVC flooring or pipes are installed) or production of PVC. Some of the production PVC waste is possible to recycle in closed loops internally at the PVC production plants. Other production waste could be collected/treated by waste management companies outside original production facilities. ${ }^{7}$ As it is very difficult to estimate how much

Waste that is recycled in closed loops at production plants, this report excludes in-house recycling from the definition of pre-consumer waste. Therefore, in this report pre-consumer PVC waste refers to waste generated in production or installation processes and handled by waste management organizations outside the original production systems.

${ }^{6}$ Plinke E., Wenk N., Wolff, Castiglione D., Palmark M., 2000. Final report to European Commission. Mechanical recycling of PVC waste. http://ec.europa.eu/environment/waste/studies/pvc/mech_recylce.pdf

7 Plinke E., Wenk N., Wolff, Castiglione D., Palmark M., 2000. Final report to European Commission. Mechanical recycling of PVC waste. http://ec.europa.eu/environment/waste/studies/pvc/mech_recylce.pdf 


\section{PVC in a European context}

\subsection{Production}

About 37 million tonnes of PVC are produced globally of which 5.5 million tonnes within Europe. PVC is the third most used plastic within Europe. ${ }^{8}$ The biggest producers of PVC resin in Europe are Inovyn (Belgium, France, Germany, Spain, UK, Norway, Sweden), Ercros (Spain), Vestolit GmbH, Shin-Etsu PVC (Netherlands, Portugal), Vinnolit GmbH \& Co. KG (Germany, UK) and Vynova Group (Belgium, France, the Netherlands, Germany, U.K), which together represent around $70 \%$ of the PVC resin manufactured within Europe. ${ }^{9}$ Inovyn is the only one of the six companies which produces PVC resin in the Nordic countries, in Sweden and Norway.

"The PVC industry" as a term is often used collectively for the PVC resin industry, the PVC additive manufacturers and the PVC compounding and converting industry. Four groups of actors can be identified within the value chain: PVC polymer producers, stabilizer producers, plasticizer producers and PVC converters. ${ }^{10} \mathrm{PVC}$ converters manufacture products made from PVC. The member organization European Plastics Converters (EuPC) consists of four divisions: packaging, building and construction, automotive and transport, and technical parts. The members are national plastics processing associations representing the plastics converting industry. Members from the Nordic countries are: Norwegian Plastics Association (Plastindustriforbundet), Danish Plastic Federation (Plastindustrien), and Swedish Plastics Association (IKEM). Finland has no member organization within EuPC. ${ }^{11}$

On a European level the PVC industry is represented by four organizations: The European Council of Vinyl Manufacturers (ECVM), European Plastics Converters (EuPC), The European Stabilizer Producers Association (espa), and European Plasticizers. ${ }^{12}$

\footnotetext{
${ }^{8}$ VinylPlus (2018). A smart material. https://vinylplus.eu/recycling/a-smart-material

${ }^{9}$ ECVM (2018a). ECVM. http://www.pvc.org/en/p/ecvm

${ }^{10} \mathrm{http} / / / \mathrm{www}$.pvc.org/en/p/pvc-converting

11 https://www.plasticsconverters.eu/

${ }^{12}$ VinylPlus (2017). Progess report 2017. Reporting on 2016 activities.
} 
Figure 1: The four associations representing the PVC industry in Europe
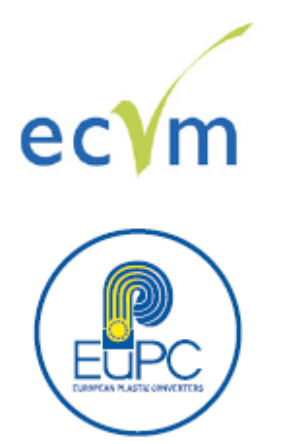

espa

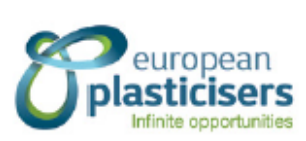

The European Council of Vinyl Manufacturers,

representing six leading European producers of PVC resin, which account for around $75 \%$ of the EU-28 PVC resin production. These businesses operate around 40 different plants spread over 23 sites, and employ approximately 7,000 people. www.pvc.org

European Plastics Converters,

an association representing close to 50,000 companies in Europe, which produce over 45 million tonnes a year of plastic products of various types. They employ approximately 1.3 million people. www.plasticsconverters.eu

\section{The European Stabiliser Producers Association,}

representing 10 companies that produce more than $95 \%$ of the stabilisers sold in Europe. They directly employ more than 2,000 people in the EU. www.stabilisers.eu

\section{European Plasticisers,}

formerly ECPI (The European Council for Plasticisers and Intermediates), representing the eight major European producers of plasticisers and intermediates. They employ approximately 1,200 people in plasticiser production. www.europeanplasticisers.eu

Source: VinylPlus (2017). Progress report 2017. Reporting on 2016 activities.

\subsection{Applications for PVC}

PVC is used in a wide variety of products for both industrial and household applications (Figure 2). The PVC material is strong, durable, lightweight and versatile; thus makes it a perfect material for many applications. More than $75 \%$ of the PVC is used in industrial applications and especially the building and construction sector where PVC products have long life span of 10-year and beyond. 
Figure 2: PVC use in different applications in the EU

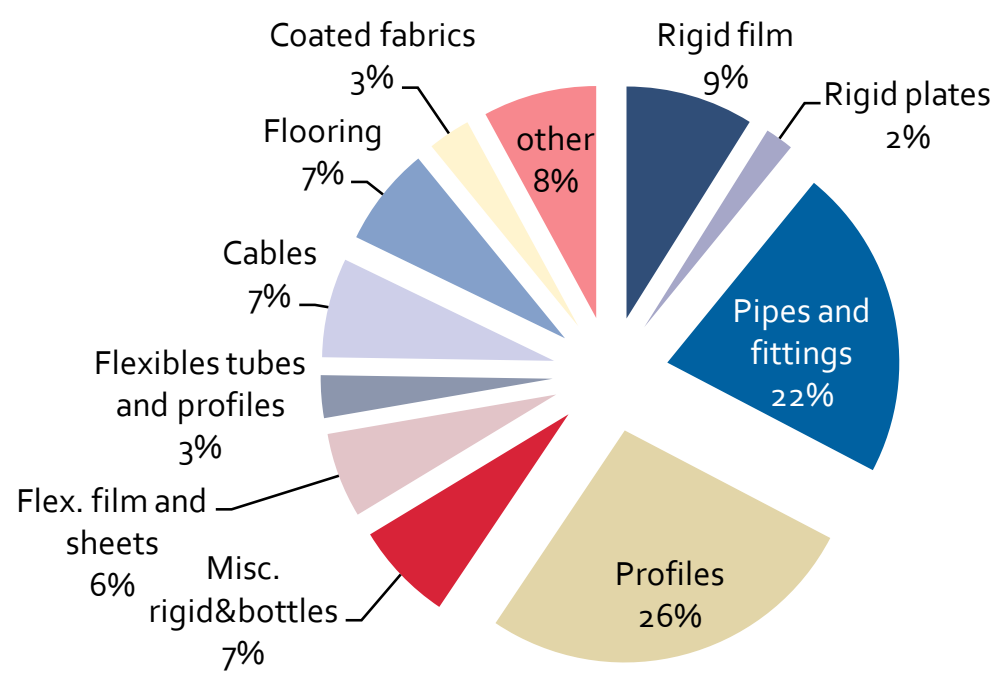

Source: https://vinylplus.eu/uploads/downloads/VinylPlus_Recycling_Technologies_30012017.pdf

\subsubsection{Construction}

The long life-span of PVC makes it a very cost-effective material. More than $60 \%$ of PVC production in Western Europe is used in buildings and within the construction sector. ${ }^{13}$ The main construction products are PVC window frames and other profile applications, pipes and fittings, electric cables and conduits, flooring, membranes and waterproofing applications in coated fabrics and a variety of plastic linings. ${ }^{14}$

\section{PVC pipes}

PVC pipes are the second biggest product group produced from PVC in the EU. In Europe, circa 3 million tonnes of plastic pipes made of PVC, PP and HDPE are produced each year. PVC is among the most widely used materials for pipes production. Compared to the alternative materials, PVC pipes are more energy-effective during production and are cost-effective in terms of durability and maintenance-free lifetime of service. PVC pipes are more durable than alternative materials and are very applicable for water, waste and drainage systems as their service time is considered to be in the rage of hundreds of years. ${ }^{15}$

\footnotetext{
13 http://www.pvc.org/en/p/pvc-for-building--construction

14 https://vinylplus.eu/uploads/downloads/VinylPlus_Recycling_Technologies_30012017.pdf

$15 \mathrm{http}: / / \mathrm{www}$.iom3.org/pvc-building-and-construction
} 


\section{Windows}

Since the 1960s, PVC has been used to produce window frames and other profiles. PVC window frames are tough and durable with a life span longer than 35 years. ${ }^{16}$

\section{Flooring}

Since the 1960's PVC has also been used to produce flooring products used in housing, hospitals and hotels. PVC is highly suitable for this application, since it can be made available in a wide range of colors, patterns and thicknesses and is easy to install and clean. ${ }^{17}$

\section{Roofing}

PVC roofing can last for over 30 years. It is easy to install and easy to maintain. ${ }^{18}$

Inflatable structures

PVC can be used to make large, strong and flexible inflatable structures. ${ }^{19}$

\subsubsection{EEE and cables}

PVC is not one of the dominant plastic types used in electrical and electronic products. The dominant ones are instead PP, ABS-SAN, PC, PE and other engineering thermoplastics such as HIPS ${ }^{20}$.

PVC is widely used in cable insulation, as it has good insulating properties, is easy to use in manufacturing processes and is highly fire resistant. PVC insulation has good mechanical and ageing characteristics, which is very important for cables.

Around 7,000 tonnes of PVC were sold for cable manufacturing in Sweden, Norway and Denmark in 2010. In 2015, between 320,000-350,000 tonnes of PVC were used to produce cables in the EU. ${ }^{21}$

\subsubsection{Vehicles}

PVC is used in automotive applications, as it is one of the most important polymers for:

- underbody coatings, sealants and floor modules;

- wire harnesses (e.g. cable insulation and grommets);

- $\quad$ passenger compartment parts (e.g. dashboard and door panels seating and arm rests);

- $\quad$ exterior parts (e.g. body side protection strips, weather strips and window sealing profiles).

\footnotetext{
${ }^{16}$ http://www.iom3.org/pvc-building-and-construction

$17 \mathrm{http}: / /$ www.iom3.org/pvc-building-and-construction

${ }^{18} \mathrm{http}: / /$ www.iom3.org/pvc-building-and-construction

19 http://www.iom3.org/pvc-building-and-construction

${ }^{20}$ PlasticsEurope (2017). Plastics the facts 2017.

${ }^{21}$ Belleza, E and Youhanan, L (2017). Rätt sak till rätt behandling - materialåtervinning, avfallsförbränning och detoxifiering av samhället. IVL Report B2278.
} 
The long lifespan of PVC materials, which are now extensively used in the manufacturing of vehicle parts and components has extended the lifetime of vehicles. By some estimates the lifetime of a modern vehicle is about 11. 5 years longer compared to vehicles produced in the 1970s. PVC has contributed largely to this as the principal protector of the underbody in the form of a wear-resistant coating, as sealant against humidity and in other protective profiles. PVC also helps in impact absorption in vehicle components, such as PVC soft dashboards, which reduces the risk of injuries during accidents. PVC coated fabrics are used for their flame resistance. PVCs are also used in air bags due to their mechanical properties. Some PVC materials are added in carpet backings, coatings and linings for added comfort and noise reduction. ${ }^{22}$

Even though PVC is used in vehicles, it is far from the most widely used plastic type. According to PlasticsEurope the most commonly used plastics in vehicles are polypropylene and polyurethane. ${ }^{23}$

\subsubsection{Health care}

Around $40 \%$ of all plastic-based medical equipment is made from PVC, mostly flexible PVC. ${ }^{24}$

The annual consumption of PVC in the health care sector in Europe is around 85,000 tonnes. As PVC materials are high performance and low cost they enable the manufacturing of many single use medical devices, which effectively replaced the traditional rubber and glass products that demanded cleaning and sterilization before reuse. Examples of medical applications of PVC are containers for blood and blood components, urine or ostomy products and tubing for blood transfusions, catheters, heart-lung bypasses and hemodialysis sets, including intra-body usages. ${ }^{25}$ Blood containers often contain DEHP as plasticizer as DEHP has a conservation effect on the red blood cells.

\subsubsection{Packaging}

In Europe more than 500,000 tonnes of PVC are used in packaging. Rigid films (60\%), flexible films such as cling (11\%) and closures are the main packaging products made of PVC. PVC can also be used in the following types of packaging: ${ }^{26}$

- Pharmaceutical tablets blisters

- Cling film for meat, fish, cheese, vegetables

- Toiletries

- Bottle sleeves (product information and labels)

- Adhesive tapes.

\footnotetext{
22 http://www.pvc.org/en/p/what-makes-pvc-so-useful-in-vehicles

23 PlasticsEurope (2017). Plastics the facts 2017.

${ }^{24}$ PVC Informationsrådet (2018). https://pvc.dk/pvc-i-samfundet/pvc-i-sundhedssektoren/

25 http://www.pvc.org/en/p/health

${ }^{26}$ http://www.pvc.org/en/p/health
} 


\subsubsection{Other applications}

PVC is also used in many miscellaneous household appliances such as credits cards, toys, bags, art and sports equipment etc. ${ }^{27}$

\subsection{VinyIPlus - the European PVC industry's voluntary commit- ment}

VinylPlus is a ten-year Voluntary Commitment of the European PVC industry consisting of PVC manufacturers, additive producers and converters. In 2000 the European associations ECVM, ECPI, ESPA and EUPC, on behalf of their members, signed the "Voluntary Commitment of the PVC Industry", which created Vinyl 2010 that later became VinyIPlus. Five challenges are the focus of VinylPlus. The challenges are controlled-loop management, organochlorine emissions, a sustainable use of additives and to achieve sustainable energy and climate stability. The fifth challenge highlights the importance of raising awareness about sustainable development.

VinylPlus has a target to recycle at least 900,000 tonnes of PVC per year into new products by 2025 , and at least one million tonnes by $2030 .{ }^{28}$

\subsubsection{Recovinyl}

Recovinyl, a part of VinylPlus, was set up in 2003 to promote PVC waste collection and recycling, and to establish an improved market for PVC recyclate. Within Recovinyl, 633,127 tonnes of recycled PVC waste were registered in 2017 making Recovinyl the biggest contributor to the target. ${ }^{29}$ Recovinyl act as a mediator between recyclers and converters and register and certify quantities of recycled PVC based on the EUCertPlast protocol. EUCertPlast means that the recycling plant is inspected by an auditor on-site. If the criteria are fulfilled a 1-year certificate is issued. Certification follows the EN 15343:2007 and covers in brief the following areas:

- Incoming material procedures and controls

- Stock management

- Recycling Process and associated mass balance calculation

- Controls on Recycled Outputs

- Environmental protection

- Subcontracting

- Quality Management and traceability. ${ }^{30}$

\footnotetext{
${ }^{27}$ http://www.pvc.org/en/p/health

${ }^{28}$ VinylPlus (2018). Voluntary Pledge. https://vinylplus.eu/recycling/voluntary-pledge

${ }^{29}$ VinylPlus (2017). Progress report 2017. Reporting on 2016 activities.

$3^{30} \mathrm{https} / / / \mathrm{www}$.eucertplast.eu/about
} 
Both PVC recyclers and converters can participate in the Recovinyl programme. Postconsumer or pre-consumer PVC waste can be delivered by certified recyclers. Recovinyl works with 3-year service agreements to be annually reviewed. Recovinyl certifies the following activities:

- the output of recycled material at the recycling facility;

- the production batches to be identified with a unique ID number;

- the percentage of recycled material, origin (post-industrial or post-consumer) and type of applications;

- input of recycled material at converters. The incoming streams with specific data \& ID numbers.

\subsection{Recycling of PVC waste in Europe}

Two main types of recycling can be distinguished, mechanical recycling and chemical recycling (also called feedstock recycling).

Chemical recycling is the process in which a polymer is chemically degraded into monomers or other basic chemicals. There are different outputs from chemical recycling, for example monomers to be used in polymerisation of new plastics or chemicals or outputs in the form of alternative fuels. Depending on the type of chemical recycling, additives can be separated from the monomers, but it can become costly and energy-intensive. There are not yet large-scale examples of chemical recycling, but there are examples. ${ }^{31} \mathrm{An}$ example of chemical recycling of PVC is the Vinyloop process (see section 2.4.1).

Around 2.5 million tonnes of PVC waste is generated every year in the $\mathrm{EU}^{32}$. As the population in the EU is around 508 million people, 33 the PVC waste generation per capita is roughly 5 kilos.

Almost 640,000 tonnes of PVC waste were recycled in 2017 within the frameworks of VinylPlus and Vinyl 2010. In 2017, the registered recycled quantities of PVC per application area within Recovinyl were ${ }^{34}$ :

- $47.8 \%$ windows and profiles

- $19.9 \%$ cables

- $18.3 \%$ Flexible PVC and films

- $12.8 \%$ pipes and fittings

- $1.4 \%$ coated fabrics.

\footnotetext{
${ }^{31}$ World Economic Forum, Ellen MacArthur Foundation and McKinsey \& Company (2016). The New Plastics Economy Rethinking the future of plastics. http://www.ellenmacarthurfoundation.org/publications

${ }^{32}$ Sevenster, A (2018). Personal communication with Arjen Sevenster, ECVM.

33 EU (2018). Att bo i EU. https://europa.eu/european-union/about-eu/figures/living_sv

34 https://vinylplus.eu/progress/annual-progress/2017-1
} 
Looking at the statistics it becomes clear that it is mostly rigid PVC waste that is recycled, representing around 60\% of the total amount of recycled PVC waste in Europe. Almost $50 \%$ of the recycled amount is represented by windows and profiles. European PVC Window Profile and Related Building Products Association (EPPA) estimates that around 300,000 tonnes of window profiles and related building products were recycled in 2017 . The main part, about $40 \%$ of post-consumer and pre-consumer windows, shutters and profiles, were recycled in Germany, 30\% in the UK and $30 \%$ in the rest of the EU-28. ${ }^{35}$

The European recycling market for PVC is indeed divided between recycling of rigid PVC waste and flexible PVC waste, simply because recycling techniques and material properties differ to a high extent. ${ }^{36}$ Big players on the European recycling market for rigid PVC waste is Van Werven in the Netherlands, Rehau and VeKa in Germany and Paprec in France ${ }^{37}$. Outside of Europe, Pakistan is the biggest competitor on the rigid PVC market. ${ }^{38}$ For polyolefins it used to be China, and after the import restrictions Malaysia and Vietnam. Malaysia and Vietnam have now implemented restrictions as well, and Indonesia has partly taken their place. ${ }^{39}$

The recycled rigid PVC is mainly used in the pipe industry as a middle layer in threelayer sewage pipes. $70 \%$ of recycled PVC can be used in such sewage pipes together with $30 \%$ virgin PVC. The price of recycled PVC is $65-70 \%$ the price of virgin PVC. There are different quality grades of rigid PVC waste; clean PVC waste and PVC waste with waste on/in it, such as rubber, silicones and metals. They are recycled in different processes to reach a high quality end product. $4^{\circ}$

The biggest challenge for the rigid PVC recycling sector is to obtain PVC waste. Van Werven, for example, could sell 2-3 times more than 12,000 tonnes per year. Export to Pakistan is one factor to the scarcity of PVC waste, but also that a lot of PVC pipes are not coming out of the ground or are part of mixed waste fractions that go to waste incineration. In addition, an increasing market for new pipes and profiles, a long lifetime of the products (up to 70 years), no closed loop for recycling (landfilling and incineration) and export outside of the EU makes it impossible to reach a high percentage of secondary raw materials in new products. ${ }^{41}$

\footnotetext{
35 VinylPlus (2017). Progress report 2017. Reporting on 2016 activities.

${ }^{36}$ Sevenster, A (2018). Personal communication with Arjen Sevenster, ECVM; Van Der Giessen, T (2018). Personal communication with Ton Van Der Giessen, CEO, Van Werven.

37 Van Der Giessen, $T$ (2018). Personal communication with Ton Van Der Giessen, CEO, Van Werven.

$3^{3}$ Van Der Giessen, T (2018). Personal communication with Ton Van Der Giessen, CEO, Van Werven.

39 Van Der Giessen, T (2018). Personal communication with Ton Van Der Giessen, CEO, Van Werven.

$4^{\circ}$ Van Der Giessen, T (2018). Personal communication with Ton Van Der Giessen, CEO, Van Werven.

$4^{11}$ Van Der Giessen, $T$ (2018). Personal communication with Ton Van Der Giessen, CEO, Van Werven.
} 


\subsubsection{VinyLoop - example of chemical recycling of PVC}

VinyLoop is a solvent-based recycling technology separating PVC from other materials such as rubber, other plastics, and textiles using selective dissolution and filtration. The recycled PVC compound can be extruded, injection moulded or calendered to various applications such as hoses, foils and shoe soles. The company VinyLoop Ferrara SpA with its plant in Ferrara, Italy, uses the VinyLoop technology and also serves as a plant for industrial research..$^{2}$ In June 2018, VinyLoop Ferrara SpA announced the closure of its recycling business in Ferrara, Italy. The production of recycled PVC compound has stopped and the company will be put in liquidation. The decision to close down the business was motivated by the collapse in demand for the special type of recycled PVC produced at the VinyLoop plant (VINYLOOPTM R-PVC). The lack of demand is driven by increasing product regulation as the recycled PVC compound contains DEHP. 43

\subsubsection{Constraints regarding recycling}

Additives used in PVC in the past, which today are subject to restrictions, can still be found in PVC waste. These additives are often called "legacy additives" by the PVC industry. In the following sub-chapter the regulatory status for the most common "legacy additives" on the EU level is described.

Lead restriction

According to the classification provided by companies to ECHA in REACH registrations, lead is very toxic to aquatic life, may cause cancer, may harm breast-fed children and damage fertility or the unborn child. Lead is classified as a substance of very high concern (SVHC) and included in the candidate list for authorization. ${ }^{44}$

In the past, lead was used as a stabilizer to protect PVC from thermal degradation and as pigment. VinylPlus made a voluntary commitment to phase out lead in PVC from December 2015. PVC waste for recycling can still contain lead as can imported PVC products. 45

ECHA is currently working on restricting the use of lead stabilizers in PVC products. ECHA's Committees for Risk Assessment (RAC) and Socio-economic Analysis (SEAC)s' proposal is that lead compounds "shall not be placed on the market or used in articles or parts thereof produced from polymers or copolymers of vinyl chloride (PVC) if the concentration of lead (expressed as metal) is equal to or greater than $0.1 \%$ by weight of the PVC material". The restriction is proposed not to apply to a number of article types containing recycled PVC for a period of 15 years from entry into force, if the concentration of lead does not exceed $1 \%$ by weight of the PVC material. This is proposed to be valid for: ${ }^{46}$

\footnotetext{
$4^{2}$ VinyLoop (2013). VinyLoop White Paper. http://www.vinyloop.com/images/doc/wp/VinyLoop_A4_ENG.pdf

43 VinyLoop Ferrara SpA (2018). CLOSURE OF VINYLOOP BUSINESS AT FERRARA, ITALY. Press release $28^{\text {th }}$ of June 2018.

${ }^{44}$ ECHA (2018a).Lead. https://echa.europa.eu/substance-information/-/substanceinfo/100.028.273

45 Sevenster, A (2018). Personal communication with Arjen Sevenster, ECVM.

${ }^{46}$ RAC and SEAC (2017). Committee for Risk Assessment (RAC) Committee for Socio-economic Analysis (SEAC) Opinion on

an Annex XV dossier proposing restrictions on lead stabilisers in PVC.
} 
- profiles and rigid sheets for building applications;

- doors, windows, shutters, walls, blinds, fences, and roof;

- gutters;

- cable ducts;

- fittings for tubes, furniture etc.;

- pipes for non-drinking water, if the recycled PVC is used in a multilayer pipe and is entirely enclosed with a layer of virgin PVC.

The opinions of ECHA's committees contribute to the decision of the European Commission. The Commission will provide a draft amendment to the list of restrictions in Annex XVII to REACH within three months of receiving the opinions. The final decision is taken involving the Member States and the European Parliament. ${ }^{47}$

\section{Cadmium restriction}

Cadmium is very toxic to aquatic life, may cause cancer, damage organs and is suspected of causing genetic defects. To place polymers containing cadmium on the European market is restricted by an amendment (Regulation 494/2011 of 20 May 2011) of Annex XVII of the REACH Regulation. Cadmium is classified as a substance of very high concern (SVHC) and included in the candidate list for authorization. ${ }^{48}$ The amendment, however, allows rigid construction products to contain cadmium if the cadmium originates from recycling, which applies to recycled PVC. Mixtures and articles of recycled PVC may contain cadmium (expressed as Cd metal) if the content does not exceed $0.1 \%$ by weight of the plastic material in the following rigid PVC applications:

- profiles and rigid sheets for building applications;

- doors, windows, shutters, walls, blinds, fences, and roof gutters;

- decks and terraces;

- cable ducts;

- $\quad$ pipes for non-drinking water if the recovered PVC is used in the middle layer of a multilayer pipe and is entirely covered with a layer of newly produced PVC.

Regulated phthalates

$\mathrm{REACH}^{49}$ (Annex XVII) restricts the use of seven groups of low-molecular weight orthophthalates that can be present in flexible PVC waste:

- $\quad$ bis (2-ethylhexyl) phthalate (DEHP)

- dibutyl phthalate (DBP)

- benzyl butyl phthalate (BBP)

\footnotetext{
${ }^{47} \mathrm{ECHA}$ (2018b). Restriction procedure. https://echa.europa.eu/regulations/reach/restrictions/restriction-procedure

$4^{8}$ ECHA (2018c). Cadmium. https://echa.europa.eu/substance-information/-/substanceinfo/100.028.320

49 https://eur-lex.europa.eu/legal-content/EN/TXT/?uri=CELEX:32006R1907
} 
- diisobutyl phthalate (DIBP)

- diisononyl phthalate (DINP)

- diisodecyl phthalate (DIDP)

- di-n-octyl phthalate (DNOP).

DINP, DIDP and DNOP are only restricted in toys and childcare articles (with a limit of $0.1 \%$ by weight). There is not a general restriction as for the other four phthalates.

Being on the authorization list (Annex XIV) means that the substances cannot be placed on the market or used after a given date, unless an authorization is granted. REACH allows companies to apply for an authorization to continue or start using and placing substances included in the Authorization List on the European market. The European Commission has granted authorization to three recycling companies for placing recyclate (considered a mixture with substances under REACH) containing DEHP, and DBP on the market:

- VinyLoop Ferrara (based in Italy, which is now closed)

- Stena Recycling (Sweden)

- Plastic Planet (Italy)

The authorization means that the companies are allowed to have DEHP and DBP (where DEHP is the main one) present in flexible PVC recyclate and put it on the European market. The authorization requirement does not apply for exported recyclates (mixtures).

The authorization requirement is only applicable on substances and mixtures including the substances. This means that if a recycler produces recyclate containing the authorized phthalates, but uses the recyclate in the same plant to manufacture finished products/articles that have ceased to be waste, the articles are allowed to be placed on the European market without authorization. This also means that imported products/articles containing authorized substances can be placed on the EU market as the REACH authorization requirement is not valid for products/articles.

The European Commission has proposed to ban the use of DEHP, DBP, BBP and DIBP in finished products/articles. The proposal was accepted by the EU member states in the EU REACH committee and implementation of the ban will most likely take place in 2020. The proposal from the European Commission means that products/articles is not allowed to be on the EU market in a content exceeding 0.1 weight percent. This will also be valid for imported products to the EU market. The limit value is valid either for an individual phthalate or as the sum of the four phthalates..$^{50}$

As well as being subject to authorization, DEHP, DBP, and BBP are restricted in all toys and childcare articles (limit of $0.1 \%$ by weight).

$5^{0}$ Sevenster, A (2018). Personal communication with Arjen Sevenster, ECVM. 
DEHP, BBP, DBP and DIBP will also soon be restricted by the RoHS Directive (Restriction on Hazardous Substances in electrical and electronic equipment). The restriction will entry into force 22 July 2019 (or 22 July 2021 for medical devices)..$^{1}$

${ }^{51}$ DIRECTIVE 2011/65/EU OF THE EUROPEAN PARLIAMENT AND OF THE COUNCIL of 8 June 2011 on the restriction of the use of certain hazardous substances in electrical and electronic equipment (recast). 


\section{PVC put on the Nordic market}

Around $300,000-330,000$ tonnes of PVC are put on the Nordic market annually, both as PVC and PVC goods according to statistics on foreign trade (exports and imports of goods) and production of commodities. The amount is probably higher, but due to secrecy reasons not all quantities of production are presented in the statistics. Product codes containing the search words polyvinyl chloride or polymers of vinyl chloride were identified, and form the basis for the estimate. Product codes containing only PVC and product codes containing PVC mixed with other substances were included, see Appendix 2. The quantity put on the market is dominated by product codes containing only PVC, hence the potential overestimation in the goods containing PVC and other substances is probably of minor importance. In Table 2, the estimated amounts of PVC (product codes containing PVC mixed with other substances) are presented. The interval represents the figures for 2015 and for 2016 respectively. The amount of PVC put on the market, the imports, exports and production data do not differ much between the two studied years.

Table 2: Quantity of PVC put on the market in the Nordic countries in 2015 and 2016 based on official statistics from each country

\section{Country Quantity of PVC put on the market annually (2015/2016) (tonnes)}

Note: *The value is probably higher (all production data are not presented in the statistics due to secrecy reasons or no reported data, see Appendix 2).

In Table 3 the quantity of PVC goods put on the Nordic market is estimated. Adding the quantities of PVC in Table 2 and Table 3 together would lead to double counting, if you are interested in the amount that reaches final consumption. The figures in Table 3 include both product codes containing only PVC and product codes containing PVC mixed with other substances. Despite this, the amounts of PVC are probably underestimated as many products contain plastic, including PVC, even though it is not always specified in the $\mathrm{CN}$-system. 
Table 3: Quantity of PVC goods put on the market in the Nordic countries in 2015 and 2016 based on official statistics from each country

Country Quantity of PVC goods put on the market annually (2015/2016) (tonnes)

Note: *The value is probably higher (all production data are not presented in the statistics due to secrecy reasons or no reported data).

According to the statistics, more PVC is put to the market in Sweden compared to the other Nordic countries, both when it comes to PVC and PVC goods. The second largest quantity of PVC is put on the Danish market followed by Finland. The quantities of goods containing PVC are second largest in Finland followed by Denmark, but the difference is small. Of the Nordic countries, Norway is the country with the lowest quantity of PVC put on the market, seen both to quantities of PVC and PVC goods. However, these figures are probably higher in reality, especially in Norway and Finland, as not all production data are presented in the statistics due to secrecy reasons or no reported data.

For instance, according to the Finnish Plastics Industries Federation, the size of the internal PVC market in Finland is about 50,000 tonnes per year. That is the amount put on the domestic market annually..$^{2}$ In Norway, according to an interview with one pipe producer, the company alone indicated producing 13,942 tonnes of PVC pipes for the Norwegian market (in 2016).

For a detailed method of how the amounts in Table 2 and Table 3 were calculated, see Appendix 2.

According to VinylPlus the total sold amount of PVC resin in the Nordic countries was about 140,000 tonnes in 2017, of which three quarters were used in the production of construction products. ${ }^{53}$

Inovyn is the only company with production of PVC resin in the Nordic countries, namely in Sweden (Stenungsund) and Norway (Porsgrunn). Inovyn is the biggest manufacturer of PVC in Europe, and among the top three PVC manufacturers worldwide. ${ }^{54}$

In Stenungsund, around 200 tonnes of PVC is produced annually, 55 and 200,000 tonnes is produced in Porsgrunn. ${ }^{56}$ This can be compared to the numbers above in Table 2 and Table 3, which are much lower due to the lack of production data in the statistics.

The Nordic countries comprise a wide range of companies manufacturing products that entirely or partly consist of PVC. A non-exhaustive list of product manufacturers using PVC (examples) based on interviews and trade organizations is presented in Table 4.

\footnotetext{
$5^{2}$ Kärhä V. (2018). Personal communication with Vesa Kärhä, Finnish Plastic Industries Federation.

53 Sevenster, A (2018). Personal communication with Arjen Sevenster, VinylPlus.

54 Inovyn (2018a). www.inovyn.com

55 Inovyn (2018b). Figures from 2014. www.inovyn.se

${ }^{56}$ http://www.ineos.no/index.php/produksjon-a-produkter/28-produksjon-og-produkter/38-pvc
} 
Table 4: Examples of product manufacturers using PVC in the Nordic countries

\begin{tabular}{|c|c|c|c|}
\hline Denmark & Finland & Norway & Sweden \\
\hline Wavin (pipes) & Upofloor (flooring) & Pipelife Norge AS (pipes) & Bolon (flooring) \\
\hline Uponor (pipes) & Oy KWH Pipe Ab (pipes) & Protan AS (roof foil) & Tarkett (flooring) \\
\hline Primo (pipes) & Uponor (pipes) & $\begin{array}{l}\text { Laerdal Medical AS (medi- } \\
\text { cal products) }\end{array}$ & $\begin{array}{l}\text { Ineos Compounds (PVC } \\
\text { compound) }\end{array}$ \\
\hline Plastmo (pipes) & Suomi Oy ja Pipelife (pipes) & $\begin{array}{l}\text { Polyform AS (Inflatable bu- } \\
\text { oys) }\end{array}$ & Riflex film \\
\hline Icopal (pipes) & Finland Oy (pipes) & $\begin{array}{l}\text { Industriplast AS (profiles } \\
\text { and pipes) }\end{array}$ & Pipelife (pipes) \\
\hline Pipelife (pipes) & $\begin{array}{l}\text { Scantarp (tarpaulin materi- } \\
\text { als) }\end{array}$ & $\begin{array}{l}\text { Venta Windows UAB (win- } \\
\text { dows) }\end{array}$ & Protan \\
\hline $\begin{array}{l}\text { Carmo (medical } \\
\text { equipment) }\end{array}$ & Upofloor (flooring) & H-Produkter AS (profiles) & Gislaved folie \\
\hline \multirow[t]{2}{*}{ Thevinyl (PVC compound) } & Oy KWH Pipe Ab (pipes) & Norsk Wavin AS (pipes) & Deflamo \\
\hline & & Tarkett (flooring) & Plastfönster i Avesta \\
\hline
\end{tabular}

Imports and exports of waste of PVC

About 2,000-4,000 tonnes of PVC waste were exported yearly from Sweden in 2015 and 2016 and $145-500$ tonnes were imported. The exports from Denmark are about 900-1,600 tonnes yearly and the imports $0-160$ tonnes. In Norway, there were no imports or export of PVC waste in 2016 and in 2015 the exports were 9 tonnes whereas there were no imports. In Finland, the exports of PVC waste are 400-2,800 tonnes yearly and the imports 1-185 tonnes. See table $12-34$. 


\section{PVC waste in Denmark}

The responsibility for waste management in Denmark is shared between The Danish Energy Agency (Energistyrelsen) and The Danish EPA (Miljøstyrelsen). The Danish Energy Agency is responsible for the structural and economic framework of the waste management area, and also for rules about which parts of collection and treatment of waste that should be under municipal responsibility and how the waste management is financed. The Danish Energy Agency is also responsible for administrating rules about the energy sector including waste-to-energy. The Danish EPA has responsibility for a number of areas within waste management, for example classification of waste, rules about producer responsibility, prevention, import and export of waste, as well as the national waste data system. ${ }^{57}$

The resource strategy "Danmark uden affald $2013^{158}$ together with the resource plan for 2013-201859 form the strategic basis for waste management in Denmark. In September 2018, the Danish government also published a national strategy for circular economy in Denmark: "Mere værdi og bedre miljø gennem design, forbrug og genanvendelse". The strategy includes six areas where actions are needed and 15 initiatives where several are relevant for the waste management sector. PVC is mentioned once in the strategy, in the political agreement on a common strategy/actions in the chemical area, where DKK 4 million are dedicated to actions regarding hazardous substances in PVC and substitution to other material types. ${ }^{60}$ The first step in this plan has just been finalized and is pending publication. It is 140 pages long report called "Mapping of PVC in Denmark" The results in the report will be used to define the need for studies to define a new Danish PVC strategy. ${ }^{61}$

Besides the more overall strategic documents regarding waste management in Denmark, the Danish government is working on a Danish action plan for plastics. A draft of the action plan is expected during 2018. The Danish Action plan for plastics will not deal with PVC issues in detail. PVC is dealt with in the Chemical Action Plan (2018-2021). ${ }^{62}$

\footnotetext{
57 The Danish Energy Agency (2018). https://ens.dk/ansvarsomraader/affald/energistyrelsen-og-affaldsomraadet

${ }^{8} 8$ The Danish Government (2013). Ressourcestrategien Danmark uden affald 2013

59The Danish EPA (2014). Danmark uden affald Ressourceplan for affaldshåndtering 2013-2018. Vejledning fra Miljøstyrel-

sen nr. 4, 2014

${ }^{60}$ Ministry of Environment and Food of Denmark (2018). Mere værdi og bedre miljø gennem design, forbrug og genanvendelse".

${ }^{61}$ Grøndahl Hansen, O (2018). Personal communication with Ole Grøndahl Hansen, PVC Informationsrådet.

${ }^{62}$ Grøndahl Hansen, O (2018). Personal communication with Ole Grøndahl Hansen, PVC Informationsrådet.
} 


\subsection{Legislation}

Waste management in Denmark is regulated in the environmental protection law (consolidation Act no 879, 26 June 2010) and the related ordinances (bekendtgørelser), especially in the Danish waste ordinance (Affaldsbekendtgørelsen ${ }^{63}$ ). The waste ordinance includes several paragraphs regulating PVC waste collection and treatment (freely translated):

"\$33: Municipalities shall establish a collection system for PVC waste. The collection system shall be organized so that both recyclable and non-recyclable PVC waste is collected.

Municipalities shall guarantee that substantial parts of the collected recyclable PVC waste are recycled, and that substantial parts of the collected non-recyclable PVC waste are landfilled.

If the municipality enters into agreement with a business taking care of PVC waste for recycling or landfill, the municipality shall secure that recyclable PVC waste and PVC waste for landfill is sorted and delivered to a facility where the recyclable PVC waste is recycled or to a facility where non-recyclable PVC waste is landfilled.

$\int 43$ : The municipality shall establish a collection system for non-recyclable PVC waste, and secure that substantial parts of the non-recyclable PVC are landfilled. If the municipality enters into agreement with a business taking care of PVC waste for landfill, the municipality shall secure that PVC waste for landfill is sorted and delivered to a facility where non-recyclable PVC waste is landfilled.

\51: The municipality shall ensure that PVC waste is not incinerated."

In summary, the Danish waste legislation obliges municipalities to collect PVC waste separately, and to send recyclable PVC waste to recycling and non-recyclable PVC waste to landfill. They are also obliged to avoid incineration of PVC waste.

\subsubsection{Ordinances on cadmium and lead}

The Danish government has adopted ordinances prohibiting cadmium and lead in products put on the Danish market. The aim of the ordinance on lead ${ }^{64}$ is to avoid lead in the environment and to avoid that lead is present in products and thereby also in waste. According to the ordinance it is prohibited to import or sell products on the Danish market if they contain lead in any form with a content exceeding 0.01 weight percent (100 ppm), which is stricter than EU regulations and the proposal from ECHA's Committees for Risk Assessment (RAC) and Socio-economic Analysis (SEAC)s' proposal (see section 3.5.2). The Danish rules for lead do not apply for exported products.

The ordinance on cadmium ${ }^{65}$ prohibits import, sale and production of products containing more than $75 \mathrm{ppm}$ of cadmium in pigments and plastic stabilizers.

\footnotetext{
63 BEK nr 1309 af 18/12/2012.

${ }^{64}$ Bekendtgørelse om forbud om import og salg af produkter, der indeholder bly, nr. 856 af 5. sep. 2009.

${ }^{65}$ Bekendtgørelse om forbud mod import, salg og fremstilling af cadmiumholdige varer. $\mathrm{nr} 858$ af 05/09/2009
} 
4.1.2 PVCfee

In 1999, a fee on PVC and phthalates was implemented in Denmark. ${ }^{66}$ The aim of the fee was to decrease the amount of PVC waste that goes to incineration and landfill as well as the use of phthalates. This was motivated as treatment of PVC waste was considered problematic, for example in the way that incineration of PVC produces hydrochloric acid, which requires neutralization in the form of flue gas cleaning, which in turn generates hazardous waste. Besides, some phthalates were suspected of having hazardous properties. ${ }^{67}$

The fee has been revised several times since 1999, and the latest version of the fee is from 2017. ${ }^{68}$ In 2004, rigid PVC was exempted from fee as it was considered suitable for mechanical recycling. The weight of the PVC plus the weight of the phthalates in general form the basis for the fee. The fee is calculated based on the expected content of PVC and phthalates in different kinds of products. The fee is DKK 2 per kg PVC and DKK 7 per $\mathrm{kg}$ phthalate, and put on products produced in Denmark and imported to Denmark. The fee is refunded for exported goods. ${ }^{69}$ In 2012, the fee yielded DKK 20 million. ${ }^{70} \mathrm{~A}$ list of products and their respective fee is listed in Appendix 1. In 2017, the Danish Government agreed to lift the fee on soft PVC. The Parliament is said to vote on this on 25 October 2018. The bill is expected to be passed because a majority in the Danish Parliament is in favour to lift the fee. Therefore there will be no fees on either rigid or soft PVC in Denmark. ${ }^{71}$

Since January 1999 there is also a weight-based fee based on flexible PVC film used in packaging. The aim of the fee is to create incentives for more environmentally friendly packaging. The fee on flexible PVC films will also be lifted in the new regulation.

\subsection{Generation of PVC waste}

It is difficult to estimate the total amount of generated PVC waste as the life expectancy of PVC products ranges from a few years for some consumer goods to several decades for building materials. Some PVC-products, e.g. drain pipes, might not end up as waste at all as they will not necessarily be removed after end usage.

OECD (2004) estimated that the annual generation of PVC waste in Denmark will be around 35,000 tonnes in 2020, a rise from 25,000 tonnes in 2004. In a report from the Danish EPA from $2015^{72}$ it was suggested that around 29,000 tonnes of rigid PVC waste was generated in 2012. In the new report from the Danish EPA to be published soon the figure

\footnotetext{
${ }^{66}$ Lov om afgift på polyvinylklorid og ftalater, lov nr. 954 af 20. december 1999.

${ }^{67}$ The Danish EPA (2014). Danmark uden affald Ressourceplan for affaldshåndtering 2013-2018. Vejledning fra Miljøstyrelsen nr. 4, 2014.

${ }^{68}$ Lovbekendtgørelse $\mathrm{nr} .1110$ af 19. september 2017 om afgift af polyvinylklorid og ftalater (Pvc-afgift).

${ }^{69}$ Skatteministeriet (2017). http://www.skm.dk/skattetal/satser/satser-og-beloebsgraenser/pvc-afgiftsloven

70 The Danish EPA (2014). Danmark uden affald Ressourceplan for affaldshåndtering 2013-2018. Vejledning fra Miljøstyrel-

sen nr. 4, 2014.

${ }^{71}$ Grøndahl Hansen, O (2018). Personal communication with Ole Grøndahl Hansen, PVC Informationsrådet.

72 Danish EPA (2015). Genanvendelse af hård PVC i Danmark. Miljøprojekt nr. 1717, 2015.
} 
for PVC waste in Denmark is estimated to be 30,000 tonnes for rigid PVC waste and 36,000 tonnes for soft PVC per year73, around $11 \mathrm{~kg}$ per inhabitant, which is much higher than the previous estimates.

\subsection{Collection}

Separately collected PVC waste is reported to the Danish National Waste Register (Affaldsdatasystemet). Facilities sorting or treating waste as well as businesses importing or exporting waste have to report collected and treated quantities of waste to the register according to the Ordinance on the waste data system (Bekendtgørelse om Affaldsdatasystemet74). The statistics includes separately collected amounts of PVC waste, but the amounts are not divided into rigid and flexible PVC.

According to the latest Danish waste statistics from 2016 a total of 7,000 tonnes of PVC waste were collected separately, of which 2,000 tonnes came from households. As the data only includes separately collected amounts, the figure does not say anything about the total amount of generated PVC waste in Denmark. In 2014 and 2015 the corresponding figures were 5,000 tonnes of separately collected PVC waste. 3,000 tonnes of PVC waste were reported to be exported outside of Denmark in 2016.75

The meaning of the terms recyclable and non-recyclable PVC waste, terms that are used in the Danish ordinance on waste, are interpreted in guidelines published by the Danish EPA in 2001, targeted at Danish municipalities about recycling and landfill of PVC. ${ }^{6}$ The guidelines have photos and descriptions of PVC products (examples) that should be sent to recycling and which products that should be landfilled, i.e. PVC waste that is considered recyclable and non-recyclable. Rigid PVC products are considered recyclable in the guidelines whereas flexible PVC products are instructed to be landfilled. In Table 5, a summary of the guidelines' recommendations of PVC to recycling and landfill is listed.

\footnotetext{
73 Grøndahl Hansen, O (2018). Personal communication with Ole Grøndahl Hansen, PVC Informationsrådet.

74 BEK $\mathrm{nr} 1511$ af 04/12/2017.

75 The Danish EPA (2018). Affaldsstatistikken 2018

$7^{76}$ The Danish EPA (2001). Håndbog til hjælp ved sortering af PVC-affald.
} 
Table 5: Recommendations on recycling and landfill of different PVC products

Drainage pipes incl. connections

Flooring

Sewage pipes incl. connections

Flexible panels

Water pipes incl. connections

Gutters

Door and window profiles, strips and panels

Roof panels

Cable channels and insulation

Blinds

Inflatable swimming pools

Swimming and bathing equipment (beach balls etc.)

Hoses

Roof foil

Ventilation pipes

Artificial leather

Tarpaulins

Rain clothes and wellingtons

Tents

Carpets

Source

The Danish EPA (2001). Håndbog til hjælp ved sortering af PVC-affald.

As a result of the legislation and guidelines published by the Danish EPA, Danish municipalities have set up separate collection of rigid PVC waste and flexible PVC waste at manned recycling centres throughout Denmark. Vestforbrænding, for example, is operating 24 manned recycling centres where PVC waste is collected. Rigid and flexible PVC waste is collected at the manned recycling centres following the guidelines from the Danish EPA from 2001. ${ }^{77}$ Vestforbrænding sends rigid PVC waste to Van Werven after some level of pre-sorting. In some cases Marius Pedersen takes care of the collected amounts. Around 680 tonnes of rigid PVC waste was sent to recycling from 18 out of the 19 municipalities (covering 700,000 citizens, excluding Copenhagen) in 2017. Flexible PVC waste is collected as part of a mixed fraction dedicated to landfill. ${ }^{78}$

Rigid PVC waste is not always separately collected at manned recycling centres in Denmark. It can also be collected together with other rigid plastics (PP and PE) and thereafter separated according to plastic type.

Vestforbrænding also owns Denmark's largest waste-to-energy plant. In 2017, around 562,000 tonnes of household and commercial waste was treated for energy recovery at the plant. The plant is owned by 19 Danish municipalities (of a total of 98), and is consequently one of the biggest municipal waste companies in Denmark. ${ }^{79}$

\subsubsection{PVC in construction and demolition waste}

The main part of the separately collected rigid PVC waste is collected through the WUPPI system.

WUPPI stands for Wavin, Uponor, Plastmo, Primo, and Icopal, the owners and initiators of WUPPI. ${ }^{80}$ WUPPI A/S was established in 1997 as a nationwide collection system for rigid PVC waste from construction by producers and importers of rigid PVC products. In

\footnotetext{
77 The sorting instructions for rigid and flexible PVC waste are those communicated by the Danish EPA in 2001

${ }^{78} \mathrm{Kiil}, \mathrm{A}$ (2018). Personal communication with Anders Kiil, Vestforbraending.

79 Vestforbrænding (2018). https://www.vestfor.dk/Om-Vestforbraending

${ }^{80}$ WUPPI (2018). https://www.wuppi.dk/medlemmer/
} 
1998, there was a PVC fee implemented in Denmark, but some rigid PVC products were exempt, such as pipes and profiles, as the PVC industry initiated a collection and recycling system for such products. ${ }^{81}$ In November 2003, the Danish EPA entered into agreement with WUPPI A/S based on the "Action plan for collection and recycling of discarded products of rigid PVC". Included in the agreement was a guarantee from WUPPI to be open about the results of the collection system, and annually report collected amounts. ${ }^{82}$

In practice, WUPPI is a collection system for rigid PVC waste from construction and demolition, more precisely the collection system accepts:

- drainpipes

- water pipes

- sewage pipes

- cable channels

- door and window profiles

- panels and gutters

The collection system includes around 1,000 users, the main part being private companies, but also municipalities and waste management companies take part in the system. $80 \%$ of the municipalities of Denmark are part of the collection system.

In the beginning the collected PVC waste was sent to Swerec in Sweden, but due to lack of transparency and costly transportation the cooperation with Swerec ended. Cooperation with Dansk Affald A/S was instead established, and later this was changed to Tönsmeier in Germany. Genbrug Midt A/S was in charge of the collection, but when they went into bankruptcy, agreement was reached with Marius Pedersen A/S in 2015. ${ }^{83}$ In 2018, it is still Marius Pedersen who carries out the collection of the rigid PVC waste on behalf of WUPPI. Containers are typically placed at municipal recycling centres or at construction sites. The PVC waste is sorted out from the other plastic types manually as well as with density separation where PVC is heavier than PP and PE.

Around 2,500 tonnes of rigid PVC were collected within the WUPPI system according to the latest statistics. During recent years this amount has been rather similar. Marius Pedersen operates the collection of the waste, and sorts it in Denmark before transporting it for recycling. There are currently twelve members in WUPPI, and they together cover the costs for the system depending on their market share of the products the WUPPI system involves. In addition, WUPPI is financed by VinylPlus with around EUR 20,000 per year. The reason why the practical operation of the system is outsourced is to cut down on costs by making the operation as professional as possible. The biggest challenge of the WUPPI system is the costs. ${ }^{84}$

\footnotetext{
${ }^{81}$ Sundqvist, J and Fråne A (2013). Återvinning av plastavfall från byggsektorn. IVL Report B2127.

82 Danish EPA (2015). Genanvendelse af hård PVC i Danmark. Miljøprojekt nr. 1717, 2015.

${ }^{8} 3$ Danish EPA (2015). Genanvendelse af hård PVC i Danmark. Miljøprojekt nr. 1717, 2015.

84 Jensen, K (2018). Personal communication with Knud Jensen, CEO of WUPPI.
} 
There are other actors on the Danish market collecting the same PVC fractions as Marius Pedersen on behalf of WUPPI, for example RGSgo and Ragn-Sells. ${ }^{85}$ In some cases rigid PVC waste is collected with other rigid plastics than PVC.

\subsubsection{WEEE and cables}

The WEEE directive was implemented in Denmark in 2005 through an amendment to the Danish Environmental Protection Act and the WEEE Statutory Order (Elektronikaffaldsbekendtgørelsen). Collection of WEEE in Denmark is mainly carried out by four producer responsibility organisations:

- Elretur

- ERP Danmark ApS

- LWF - Lyskildebranchens WEEE forening

- RENE

WEEE treatment in Denmark is limited, and is mainly focused on pre-treatment and dismantling rather than end-of-life operations. ${ }^{86}$ Dismantling and pre-treatment are both manually and mechanically operated. Mechanical pre-treatment in the form of shredding crushes the fractions in smaller pieces to allow sorting into different material fractions that are either sent to recycling, energy recovery or landfill. Energy recovery and landfill typically take place in Denmark whereas recycling operations occur outside of Denmark. ${ }^{87}$ Recycling of WEEE is focused on abstracting the value of metals, and not on plastics. The project group has not found any information showing that PVC from WEEE is recycled. PVC in cables can however be recycled using the PlastSep process, which takes place at some pre-treatment facilities for WEEE in Denmark (see section 8.4).

\subsubsection{End-of-life vehicles}

End-of-life vehicles are dismantled from hazardous components and thereafter sent to shredding where abstracting metals for recycling is the main focus. Shredding of ELVs and other waste fractions such as white goods also generate shredder waste (shredder light fraction, SLF). In Denmark, around 100,000-150,000 tonnes of shredder waste is generated annually of which a big part is landfilled as hazardous waste.

\footnotetext{
85 Grøndahl Hansen, O (2018). Personal communication with Ole Grøndahl Hansen, PVC Informationsrådet.

${ }^{86}$ Kjellsdotter Ivert, L., Raadal, H., Fråne, A., Ljungkvist H (2015). The role of the WEEE collection and recycling system setup on environmental, economic, and socio-economic performance. IVL Report B2243.

${ }^{87}$ The Danish EPA (2014). Danmark uden affald Ressourceplan for affaldshåndtering 2013-2018. Vejledning fra Miljøstyrelsen nr. 4, 2014.
} 
To retain more valuable resources from shredder waste is a focus area in the Danish resource plan for waste management 2013-2018 and in the resource strategy. ${ }^{88}$

PVC present in end-of-life vehicles ends up in the shredder waste fraction. The amount of PVC in shredder waste is not known, but in 2017 around 110,000 end-oflife vehicles were shredded in Denmark (based on disbursed money for scrapping). ${ }^{89}$ ELVs are shredded at facilities owned by Stena or H.J. Hansen Genvindingsindustri A/S in Denmark. ${ }^{\circ 0}$

If it is assumed that $2-3 \%$ of the shredded vehicles consist of $P V C^{91}$, a total of $1,760-2,970$ tonnes $^{92}$ of PVC from ELVs end up in the shredder waste that is either landfilled as hazardous waste or incinerated. However, an unknown amount of PVC cable could be separately dismantled from the ELVs.

\subsubsection{Health care}

There is no readily available statistics for the amount of PVC waste generated or collected from the Danish health care sector. As for most plastic waste from the health care sector, PVC waste is likely to be sent to energy recovery together with mixed waste fractions, and thus not subject to separate collection.

\subsubsection{Packaging}

Roughly $30 \%$ of the plastic packaging waste was collected for recycling from households in Denmark in 2015. Collection of plastic packaging waste occurs mainly through kerbside collection from households or from municipal recycling centrals. The plastic packaging is sometimes pre-sorted before it is sent to mechanical recyclers abroad. ${ }^{93} \mathrm{PVC}$ present in the plastic packaging flow is generally not recycled.

\subsubsection{Other PVC waste}

Pre-consumer PVC waste from PVC product manufacturing is often recycled internally at the manufacturing plants why the amounts are not included in the waste statistics. There are no statistics on the separately collected pre-consumer waste that is collected by waste companies and sent to recycling from product manufacturers, although they could partly be included in the PVC waste statistics.

\footnotetext{
${ }^{88}$ Fruergaard Astrup, T (2015). Udnyttelse af shredderaffald - Fra strategi til handling. Presentation at DAKOFA seminar 6th of June 2016 by Thilde Fruergaard Astrup, the Danish EPA.

${ }^{89}$ DPA System (2018). ELV statistik 2017. https://www.dpa-system.dk/da/DPA/Statistik/Biler-ELV

$9^{90}$ Hansen, J B (2018). Personal communication with Jette Bjerre Hansen, DAKOFA.

${ }^{91}$ Cullbrand, K (2018). Personal communication with Klas Cullbrand, Chalmers Industriteknik.

$9^{2}$ Based on a weight of an ELV of 800-900 kg.

93 DAKOFA (2018b).
} 


\subsection{Treatment of PVC waste}

The separately collected PVC waste (around 7,000 tonnes) was in 2016 treated as follows according to the waste data system: ${ }^{94}$

- recycling: 6,824 tonnes

- energy recovery: 4 tonnes

- landfill: 169 tonnes.

\subsubsection{Recycling}

Recycling of post-consumer PVC waste in the sense that the recyclate generated is used in products put on the Danish market is not possible due to the ordinances on lead and cadmium. The collected post-consumer PVC waste containing lead and cadmium or the recyclate containing lead and cadmium need to be exported outside of Denmark to enable recycling into new PVC products. Pre-consumer PVC waste without lead and cadmium can be recycled into new products in Denmark, but there are no statistics on the amounts available. ${ }^{95}$

\subsubsection{Energy recovery}

3.56 million tonnes ${ }^{96}$ of waste, of which around 550,000 tonnes are imported waste, were recovered for energy at 26 waste-to-energy plants fuelled by waste, and at four plants using waste and other fuels in 2016.97 These figures exclude import of waste to incineration in Denmark's two facilities for hazardous waste and to the cement industry. ${ }^{98}$ Most of the facilities are owned by municipalities.

The Danish legislation regarding PVC waste makes it clear that energy recovery of PVC waste should be avoided. The reluctance to incinerate PVC waste in Denmark is likely based on a report from the Danish EPA in 1995. The chlorine content in the incinerated waste was estimated, and it was established that two thirds of the chlorine comes from PVC waste. It was also concluded that a removal of PVC from energy recovery would lead to savings for the society of between DKK 25 million to DKK 33 million (in 1995) due to cost reductions for flue gas cleaning and treatment of ashes. ${ }^{99} \mathrm{In}$ the new report from the Danish EPA to be published it is concluded that PVC waste is responsible for less than $5 \%$ of the neutralization residues from energy recovery. ${ }^{100}$

Even though PVC waste according to Danish law shall be collected separately, there is PVC waste that ends up in mixed waste fractions that are sent to energy recovery. If the

\footnotetext{
94 Affaldsdata (2017). Affaldsdata 2016 - rådata.

95 Grøndahl Hansen, O (2018). Personal communication with Ole Grøndahl Hansen, PVC Informationsrådet.

${ }^{96}$ The Danish EPA (2018). Affaldsstatistikken 2016.

97 The Danish Energy Agency (2018). Kapacitet til affaldsforbrænding i Danmark.

$9^{8}$ The Danish EPA (2018). Affaldsstatistikken 2016.

99 The Danish EPA (1995). Affaldsforbraending i forbindelse med PVC-avtalen.

${ }^{100}$ Grøndahl Hansen, O (2018). Personal communication with Ole Grøndahl Hansen, PVC Informationsrådet.
} 
estimated amount of total generation of PVC waste is used as a rough comparison it means that the majority of the generated amounts of PVC waste are sent to energy recovery in mixed waste fractions in Denmark, and not separately collected for landfilling or recycling as the legislation states.

In Denmark there is also a tax on incineration of waste.

\subsubsection{Landfill}

Landfilling of waste in Denmark is regulated in the ordinance on landfilling ${ }^{101}$ This piece of legislation does not, however, instruct specifically about how to landfill PVC waste. Combustible waste is banned from landfilling since 1997. Landfilling of waste is subject to a landfill tax of DKK 475 per tonne waste. ${ }^{102}$

According to the latest waste statistics from 2016, around 170 tonnes of PVC waste were landfilled in Denmark. The flexible PVC waste that is landfilled can be collected separately or together with other waste fractions subject to landfilling.

\subsection{Summary of PVC waste generation, collection and treatment in Denmark}

In Table 6, the available estimates and statistics regarding PVC waste generation, collection and treatment in Denmark is listed.

\footnotetext{
${ }^{101}$ Bekendtgørelse nr. 1049 af 28. august 2013 om deponeringsanlæg.

${ }^{102}$ Bekendtgørelse af lov om afgift af affald og råstoffer (affalds- og råstofafgiftsloven). LBK nr 412 af 21/04/2017.
} 
Table 6: Overview of PVC waste management in Denmark (for data sources, see the text above)

\begin{tabular}{|c|c|c|c|}
\hline Waste stream & Generation & Collection & Treatment \\
\hline $\begin{array}{l}\text { PVC waste in } \\
\text { total }\end{array}$ & $\begin{array}{l}66 \mathrm{kt} \text { of PVC waste is es- } \\
\text { timated to be generated } \\
\text { according to a report } \\
\text { from the Danish EPA } \\
\text { soon to be published }\end{array}$ & $\begin{array}{l}7 \mathrm{kt} \text { of PVC waste was separately col- } \\
\text { lected in } 2017\end{array}$ & $\begin{array}{l}\text { The separately collected PVC waste } \\
\text { was treated as follows: } \\
\text { Recycling: } 6,824 \text { tonnes } \\
\text { Energy recovery: } 4 \text { tonnes } \\
\text { Landfill: } 169 \text { tonnes }\end{array}$ \\
\hline $\begin{array}{l}\text { PVC in con- } \\
\text { struction and } \\
\text { demolition } \\
\text { waste }\end{array}$ & No reliable estimates & $\begin{array}{l}\text { Partly separate collection. Within the } \\
\text { WUPPI system around } 2,500 \text { tonnes of } \\
\text { rigid PVC waste from construction } \\
\text { and demolition is collected annually, } \\
\text { but the total amounts are likely to be } \\
\text { higher. Soft PVC waste is dedicated to } \\
\text { landfill }\end{array}$ & $\begin{array}{l}\text { The separately collected rigid PVC } \\
\text { waste is sent to recycling abroad. }\end{array}$ \\
\hline $\begin{array}{l}\text { WEEE and } \\
\text { cables }\end{array}$ & No reliable estimates & $\begin{array}{l}\text { The amount of PVC in collected WEEE } \\
\text { and cables is not known. }\end{array}$ & $\begin{array}{l}\text { PVC in cable waste either goes to re- } \\
\text { cycling or energy recovery/incinera- } \\
\text { tion }\end{array}$ \\
\hline ELVs & No reliable estimates & $\begin{array}{l}\text { Around } 110,000 \text { ELVs are collected } \\
\text { and shredded every year. Some dis- } \\
\text { mantling of larger cable waste may } \\
\text { exist, but the amount is unknown. A } \\
\text { total of around } 1.8-2.9 \text { kt of PVC is } \\
\text { present in SLF }\end{array}$ & $\begin{array}{l}\text { SLF goes to energy recovery or land- } \\
\text { fill }\end{array}$ \\
\hline $\begin{array}{l}\text { PVC from } \\
\text { health care }\end{array}$ & No reliable estimates & $\begin{array}{l}\text { No separate collection. PVC waste } \\
\text { ends up in mixed waste fractions }\end{array}$ & $\begin{array}{l}\text { Energy recovery as hazardous or } \\
\text { non-hazardous waste }\end{array}$ \\
\hline Packaging & No reliable estimates & $\begin{array}{l}\text { Roughly } 30 \% \text { of the plastic packaging } \\
\text { waste was collected for recycling from } \\
\text { households in Denmark in } 2015\end{array}$ & $\begin{array}{l}\text { PVC in packaging waste is generally } \\
\text { sorted out as a reject fraction and } \\
\text { sent to energy recovery }\end{array}$ \\
\hline
\end{tabular}




\section{PVC waste in Finland}

There are no official statistics on PVC waste generation, collection and treatment in Finland. National waste management plans or strategies do not bring up PVC specifically.

\subsection{Legislation}

Legislation on waste collection and treatment in Finland is mainly based on EU legislation, but in some cases it includes stricter requirements than those applied in the EU. Finnish waste management is regulated through the Waste Act (646/2011) and the Waste Decree (179/2012). PVC waste is not mentioned specifically in either the Waste Act or in the Waste Decree.

National waste management plans or strategies do not bring up PVC specifically.

There is no particular regulation for PVC waste in Finland, except the general ban on waste landfilling if the share of organic content is over $10 \%$ by weight. The organics are defined as total organic carbon content (TOC) or ignition loss (LOI). The regulation entered into force in 2016 and concern PVC waste among other organic waste types (see Chapter 5.4). Recently the Ministry of the Environment issued guidelines for authorities, landfill owners and waste producers regarding what kind of PVC waste that could be given exemptions for temporary landfilling when no other feasible treatment method (recycling or energy recovery) is available. ${ }^{103}$

Other legal documents regulating waste streams where PVC might be present are:

- Government Decree (518/2014) on packaging and packaging waste

- Government Decree (519/2014) on waste of electric and electronical equipment

- Government Decree (123/2015) on end-of-life vehicles and restrictions on the use of hazardous substances in vehicles

- Government decree (331/2013) on landfills

- Government (151/2013) Decree on waste incineration. ${ }^{104}$

\footnotetext{
${ }^{103}$ Häkkinen E. (2018). Email communication with Eevaleena Häkkinen, Finnish Environment Institute (SYKE).

${ }^{104}$ http://www.ym.fi/en-US/The_environment/Legislation_and_instructions/Waste_legislation
} 


\subsection{Generation of PVC waste}

Post-consumers waste is usually co-mingled with other waste fractions and less attractive to recyclers as it has no positive financial value.

The largest share of PVC waste is generated as post-consumer waste, although there are no systematic official statistics on PVC waste generation. Based on available literature from 2000, the total amount of generated PVC waste was about 30,000 tonnes per year. ${ }^{105}$ According to project interviews, the amount today is somewhere in the range between 20,000 and 30,000 tonnes annually. ${ }^{106}$ The numbers are approximate as no separate collection of PVC waste is organized and most of the PVC waste ends up in mixed waste fractions. According to some estimates, PVC corresponds to less than $1 \%$ of the total mixed municipal solid waste (MSW) stream ${ }^{107}$ (e.g. as packaging waste, plastic outdoor coversheets, drain piping, credit cards, vinyl records, aqua toys, plastic folders and raincoats). ${ }^{108}$

No recent official statistics are available on the annual amount of PVC waste generated from e.g. WEEE, ELVs or medical waste streams. ${ }^{109,110}$ Waste PVC cable insulation is estimated at less than 100 tonnes per year (Table 7). ${ }^{111}$

The annual generation of pre-consumer PVC waste could be in the range of 1,000-3,000 tonnes. ${ }^{112}$ However, there are no official Finnish statistics. In the literature ${ }^{113}$ PVC manufacturing waste from industries is considered to be small as in many cases it is easy to reprocess it in closed loop recycling systems within the same facilities. More than half of the producers recycle over $90 \%$ of their PVC manufacturing waste internally. ${ }^{114}$

The pre-consumer PVC waste consists of approximately $57 \%$ (by weight) flexible PVC and $43 \%$ rigid PVC. ${ }^{115}$ Most of the flexible PVC waste is likely to come from coated fabrics (circa $28 \%$ of flexible PVC), roof covers, floor tiles and floor racks (circa 10\%), including different kinds of hoses. Most of the rigid PVC waste consists of pipes (27\%) and construction profiles (circa 8\%). These figures are very approximate and derived from old data. ${ }^{116}$ There are regional concentrations of pre-consumer PVC waste. The largest are in Oulu $(2,100 \mathrm{t} / \mathrm{y})$, Helsinki $(1,600 \mathrm{t} / \mathrm{y})$ and Turku regions (900 t/y). ${ }^{117}$

\footnotetext{
105 Plinke E. , Wenk N.Wolff G., Castiglione D., Palmark M., 2000. Mechanical recycling of PVC wastes. Study for DG XI of the European Commission, Final report B4-3040/98/000821/MAR/E3. ( http://ec.europa.eu/environment/waste/studies/pvc/mech_recylce.pdf).

${ }^{106}$ Based on interviews: 25- $30 \mathrm{Kt} /$ year (personal communication with Pohjakallio M., Punkkinen H (2018), VTT), min. 20 Kt/year (personal communication with Kärhä V (2018), 20-22 Kt/year (personal communication with Vaajasaari K., Ministry of the Environment.

107 Vaajasaari K. (2018). Personal communication with Kati Vaajassari, Ministry of Environment.

${ }^{108}$ Pohjakallio M., Punkkinen H. (2018). E-mail communication. VTT, 2018-07-06, Finland.

${ }^{109}$ Kärhä V. (2018). Personal communication with Vesa Kärhä, Finnish Plastic Industries Federation.

${ }^{110}$ Vaajasaari K. (2018). Personal communication with Kati Vaajassari, Ministry of Environment.

${ }^{111}$ Walavaara M. (2018). Personal communication with Marko Walavaara, Stena Recycling.

112 Based on interviews: 1 Kt/year (Vaajasaari K. (2018)), 1-3 Kt/year Pohjakallio M and Punkkinen H. (2018).

113 http://publications.jrc.ec.europa.eu/repository/bitstream/JRC91637/2014-jrc91637\%20.pdf

114 Pohjakallio M. and Punkkinen H. (2018). E-mail communication with Pohjakallio M. \& Punkkinen H., VTT.

115 Pohjakallio M. and Punkkinen H. (2018). E-mail communication with Pohjakallio M. \& Punkkinen H., VTT.

${ }^{116}$ Vaajasaari K. (2018). Personal communication with Kati Vaajassari, Ministry of Environment.

${ }_{117}$ Pohjakallio M. \& Punkkinen H. (2018). E-mail communication with Pohjakallio M. \& Punkkinen H.,VTT.:
} 
The use of PVC in windows compared to other EU countries (e.g. in East and Central EU countries) is rather small due to consumers' preferences for wooden construction. ${ }^{118}$ Retailers have recommended their suppliers to reduce PVC use in packaging, thus making it less present in packaging ${ }^{119}$.

\subsection{Collection}

There are no large-scale separate collection schemes for post-consumer PVC-waste in Finland. Some collection exists for pre-consumer PVC waste pipes.

\subsubsection{PVC in construction and demolition waste}

PVC in construction and demolition waste is often not separated and is either sent to energy recovery and/or is landfilled. Larger batches of bulky PVC waste could be collected at manned recycling centres. ${ }^{120,121}$ However, even for separately collected PVC waste the main treatment methods are either energy recovery or landfilling (if authorized and no other treatment options are available). The share between energy recovery and landfilling is not known.

Clean plastics pipes, among which some consist of PVC, have previously had a rather extended system of collection points all over Finland. ${ }^{122}$ The system was previously monitored by the Finnish Plastic Industries Federation. However, due to some difficulties related to waste collection, such as lack of motivation or skills, the Federation abandoned the system. There still are some companies within the construction sector that collect clean PVC waste from companies and even households. ${ }^{123}$ However, the collected amounts are probably minor. ${ }^{124}$ Small amounts of hard PVC pipes have been exported from Finland e.g. to Sweden and Latvia, and before 2018 some

\footnotetext{
${ }^{118}$ Provided by Maija Pohjakallio\&Henna Pukkinen, VTT, 2018-07-06, Finland.

[1] Poropudas Maria, Recycling and Reuse of Polyvinyl Chloride (PVC),Master of Science Thesis, Tampere University of Tech-nology (2011) (language Finnish) https://dspace.cc.tut.fi/dpub/bitstream/handle/123456789/21281/Poropudas.pdf?sequence $=1$

[2] Hanna Eskelinen, Teija Haavisto, Hanna Salmenperä, Helena Dahlbo,Plastics recycling- Outlook and Challenges, CLIC Innovation, Report nro D4.13 (2016) (language Finnish)

[3] Roininen, Timo, Cutting and separation of Soft PVC-materials,Bachelor's Thesis in polymer and fiber technology, Lahti University of Applied Sciences, Finland (2018). https://www.theseus.fi/bitstream/handle/10024/144444/Roin-

inen_Timo.pdf?sequence $=4$ \&isAllowed $=y$

119 https://vinylplus.eu/uploads/Modules/Documents/pvcrecycling2004.pdf

${ }^{120}$ Pohjakallio M. \& Punkkinen H. (2018). E-mail communication with Pohjakallio M. \& Punkkinen H.,VTT.

${ }^{121}$ Plastic sorting at recycling centers. Guideline TemaNord 2015:518. http://norden.diva-por-

tal.org/smash/get/diva2:791251/FULLTEXTo4.pdf

${ }^{122}$ Provided by Maija Pohjakallio \&Henna Punkkinen, VTT(2018): The collection and recycling of plastics pipes in Finland, brochure by Finnish Plastics Industries Association (2014) (in Finnish).

${ }^{123}$ Kärhä V. (2018). E-mail communication with Vesa Kärhä, Finnish Plastic Industries Federation .

124 Vaajasaari K. (2018). Personal communication with Kati Vaajassari, Ministry of Environment.
} 
waste PVC from cables has been transported to China ${ }^{125}$. However, PVC waste is classified as green-listed waste ${ }^{126}$ and thus its export within the EU/OECD is not reported by the customs. ${ }^{127}$

Only very small amounts (e.g. clean PVC pipes) have been exported for recycling.

To the projects' knowledge, other pre-consumer PVC waste is not subjected to any special collection and separation system and this waste is likely to be treated similar to post-consumer waste (mostly incinerated and in some cases landfilled).

\subsubsection{WEEE and cables}

No facilities for PVC cable waste recycling are present in Finland. The prevailing approach in the past was exporting non-granulated cable waste to Asia (e.g. China). Today this is largely not possible due to waste import restrictions recently imposed by China. The only special treatment method available in Finland today is granulation (or the cable shredding process). For instance, Stena Recycling has its own granulate plant and some cable waste is exported to Sweden. The PVC waste after cable granulation ends up being sent to energy recovery if it remains in Finland. Some of this can still contain copper. ${ }^{128}$

The collection, transportation, management and financing of WEEE in Finland are covered by extended producer responsibility (EPR) systems. There are five producer organizations for WEEE. They cooperate in terms of organizing a common collection network (about 550 collection points) and sharing the expenses. The collection points are usually located at municipal waste collection centres or private companies (e.g. Stena, Kuusakoski etc.) and producers have to arrange their placement via contracts. In addition, the retail sector has an obligation to take back small consumer equipment (without the requirement of buying new) and large equipment (only when a new one is bought). Producers (i.e. actors under EPR obligations) have to arrange and pay the collection of these products. Treatment is arranged by contracts between producers and treatment facilities. ${ }^{129}$

In 2016, circa 60,000 tonnes of WEEE were collected in Finland. 51,400 tonnes were sent for recycling, 3,000 tonnes for energy recovery and 3,600 tonnes - for disposal. ${ }^{130}$ No data are available on the amounts of plastics and PVC in WEEE. It is estimated $^{131}$ (see Chapter 7.3.4) that plastics constitute about $20 \%$ of the weight in WEEE, thus theoretically corresponding to about 12,000 tonnes. Taking into account

\footnotetext{
125 Pohjakallio M., Punkkinen H. (2018). E-mail communication with Pohjakallio M., Punkkinen H., VTT.

${ }^{126}$ Green list waste based on Appendix III of the EU Regulation on Shipment of Waste includes all types of waste that do not pose any likely risk to the environment when shipped for recovery. http://www.environment.fi/en-US/Forms_permits_and_environmental_impact_assessment/Permits_notifications_and_registration/Transfrontier_shipments_of_waste/Waste_export_and_import_guidelines/Shipping_green_list_waste

127 Pohjakallio M., and Punkkinen H. (2018). E-mail communication. VTT

${ }^{128}$ Walavaara M. (2018). Personal communication with Marko Walavaara, Stena Recycling.

${ }^{129}$ Virtanen T. (2018). E-mail communication with Teemu Virtanen, PIR-ELY.

${ }^{130}$ According to data from Teemu Virtanen (PIR-ELY).

${ }^{131}$ Baxter et al. (2014). Plastic value chains, Case: WEEE (Waste Electric and electronic equipment) in the Nordic region.

TemaNord 2014:542.
} 
that PVC in the shredded residue is about 1\% (see Chapter 7.3.4), PVC material with origins from WEEE would make circa 120 tonnes per year in Finland.

The fraction of PVC is sufficiently small that it is not separated from other plastics. In general, plastic waste from WEEE used to be sent for recycling to China. However, after China's restrictions on waste imports, plastics now go largely to energy recovery. Plastics containing flame retardants go for special energy treatment in hazardous waste plants. Only a minor part goes to landfilling. ${ }^{132}$

\subsubsection{End-of-life vehicles}

Some larger elements of PVC waste from mechanically dismantled ELVs (e.g. plastic bumpers and gasoline tanks) could be re-used/sold for re-use or exported for recycling, but it is not common practice in Finland. ${ }^{133},{ }^{134}$ Some companies, for instance Stena Recycling and Kuusakoski Oy, store larger plastic items, including those containing PVC, until they establish a plan on how to utilize it. ${ }^{135},{ }^{136}$. However, the most common practice in Finland is that ELVs are shredded and PVC ends up together with other plastics as shredder light fraction (SLF). In total 50,000-70,000 tonnes SLF is generated in Finland annually, however no official data on PVC fraction in SLF is available. ${ }^{137}$

In 2017, circa 66,000 end-of-life vehicles received certificates for destruction in Finland. ${ }^{138}$ Assuming that all vehicles will go to shredding and that $2-3 \%$ of the shredded vehicles consist of PVC, ${ }^{139}$ a total of $1,060-1,780$ tonnes ${ }^{140}$ of PVC from ELVs end up in the shredder waste.

The main treatment method for SLF is energy recovery. In 2017, the legal requirements for the SLF changed, so that SLF is no longer treated as hazardous waste making incineration in non-hazardous waste-to-energy plants possible. ${ }^{141}$

\subsubsection{Health care}

PVC used in health care ends up in mixed waste health care fractions and is classified as hazardous waste and subject to incineration for hazardous waste. ${ }^{142}$

\footnotetext{
${ }^{132}$ Virtanen T. (2018). E-mail communication with Teemu Virtanen (PIR-ELY).

133 Silvennoinen A. (2018). Personal communication with Arto Silvennoinen, Suomen Autokierrätys.

${ }^{134}$ Silvennoinen A. (2018). Personal communication with Arto Silvennoinen, Suomen Autokierrätys.

135 Walavaara M. (2018). Personal communication with Marko Walavaara, Stena Recycling.

${ }^{136}$ Kärhä V. (2018). E-mail communication with Vesa Kärhä, Finnish Plastic Industries Federation.

${ }_{137}$ Silvennoinen A. (2018). Personal communication with Arto Silvennoinen, Suomen Autokierrätys.

${ }^{138}$ http://www.aut.fi/en/statistics/scrapped_vehicles/number_of_certificates_of_destructions_yearly

${ }_{139}$ Cullbrand, K (2018). Personal communication with Klas Cullbrand, Chalmers Industriteknik.

${ }^{140}$ Based on a weight of an ELV of 800-900 kg.

${ }^{141}$ Silvennoinen A. (2018). Personal communication with Arto Silvennoinen, Suomen Autokierrätys.

${ }_{142}$ Vaajasaari K. (2018). Personal communication with Kati Vaajassari, Ministry of Environment.
} 


\subsubsection{Packaging}

Since 2016, plastic packaging waste is collected through the bring collection system, which started in connection with the producers' responsibility for packaging waste ${ }^{143}$ organized by the producer responsibility service company Rinki Oy. ${ }^{144}$ However, PVCcontaining commercial and consumer packaging (including other small PVC-containing waste items) are excluded from this system. ${ }^{145,146} \mathrm{PVC}$ packaging is collected in mixed municipal waste stream and treated mainly by energy recovery. ${ }^{147}$

\subsubsection{Other PVC waste}

According to interviews, since 2016 the recycling of pre-consumer PVC waste has received more attention due to the general ban on landfilling, China's national policy to ban plastic waste imports from the Western countries, as well as the economic rationale due to high cost of alternative (to landfilling) waste recovery. ${ }^{148}$

Some Finnish companies (e.g. Medi Seam located in Nastola) would be interested in collecting side streams from PVC-tarpaulin materials from the only company Scantarp, which produces PVC fabrics in Finland. The main part of Scantarp's side streams of PVC is excess fabrics from cutting. Annually the company recycles about 20 tonnes of this excess while about 2 tonnes are sold to other users (e.g. forest owners to guide the movement of wildlife or sports teams to be used as fence material). About 200 tonnes of Scantarp's production waste is landfilled with a special permission. ${ }^{149}$

\subsection{Treatment}

In recent years, Finland has increased efforts towards recycling and energy recovery from MSW. According to official statistics, about $47 \%$ of overall waste (excl. mineral waste) went to energy recovery and $41 \%$ went to recycling in 2016. Landfilling rates have been steadily decreasing to about $11 \%$ of the overall waste (excl. mineral waste) going to final disposal in 2016. ${ }^{150}$ There are nine incineration plants for municipal waste in Finland and one for hazardous waste operated by Fortum Waste Solutions. ${ }^{151}$ The

\footnotetext{
${ }^{143}$ Dahlbo H., Poliakova V., Mylläri V., Sahimaa O., Anderson R. (2018) Recycling potential of post-consumer plastic packaging waste in Finland. Waste Management 71, 52-61. 
latter and some of the municipal waste-to-energy plants can treat emissions of $\mathrm{HCl}$ and dioxin formed during the incineration of high chlorine-containing waste. New wasteto-energy plants (established since 2008) are capable of processing 3-5 times higher halogen levels in feedstock than SRF-user or even cement kilns. ${ }^{152}$ Only Fortum Waste Solutions can accept separately collected PVC waste for energy recovery. Other wasteto-energy plants receive it in mixed waste streams. ${ }^{153}$ However, the majority of wasteto-energy plants are not accepting PVC in larger quantities at once, as it can cause larger emissions of $\mathrm{HCl}$ and dioxins.

In 2000, the main treatment method for PVC waste was landfilling. Today, allocation between energy recovery and landfilling of PVC waste is not known, but landfilling is likely to be less applied due to general decrease of landfilling of mixed waste and the ban on landfilling organic waste. ${ }^{154}$ However, some exemptions from the landfilling regulation exist. For instance, if energy recovery is not possible (e.g. low energy density or high halogen content) and there are no other techno-economically feasible solutions available, landfilling of some organic waste may be authorized for a limited period of time. ${ }^{155}$ The exemption could be applied for PVC waste because its environmental effects are considered negligible. PVC is non-biodegradable and regarded to be inert at landfill sites. The main environmental concerns are related to accidental fires at landfills where chlorine compounds can be released into the atmosphere. ${ }^{156}$ Recently, only three local remote landfills in Finland received temporary licenses to accept limited amounts of PVC waste. ${ }^{157}$

The national ban on landfilling of organic waste, including PVC, the waste hierarchy and the EU waste legislation in general are the main drivers for diverting PVC from landfills. The negligible local capacities for domestic PVC recycling and restricted incineration permits result in some exemptions from the landfilling ban.

Waste management costs and the increasing costs for virgin raw materials motivate local industries to consider PVC recycling as an economically feasible option. ${ }^{158}$ However, the domestic recycling of PVC is severely limited by high costs and the inability to reach economies of scale. For instance, PVC waste is geographically dispersed, which inflates the costs of collection and transfer. Meanwhile the costs of sorting, management and recycling are high and the market for recycled PVC waste is weak. ${ }^{159}$

\footnotetext{
${ }^{152}$ Kärhä V. (2018). Personal communication with Vesa Kärhä, Finnish Plastic Industries Federation.

153 Vaajasaari K. (2018). Personal communication with Kati Vaajassari, Ministry of Environment.

${ }_{154}$ Häkkinen E. (2018). E-mail communication with Eevaleena Häkkinen, The Finnish Environment Institute (SYKE).

155 Provided by Maija Pohjakallio, Henna Punkkinen, VTT (2018).

${ }^{156}$ Vaajasaari K. (2018). Personal communication with Kati Vaajassari, Ministry of Environment.

157 Kärhä V. (2018). Personal communication with Vesa Kärhä, Finnish Plastic Industries Federation.

${ }^{158}$ Kärhä V. (2018). Personal communication with Vesa Kärhä, Finnish Plastic Industries Federation.

159 Provided by Maija Pohjakallio\&Henna Pukkinen (2018). E-mail communication with Pohjakallio M. \& Punkkinen H.,VTT. Roininen, Timo, Cutting and separation of Soft PVC-materials,Bachelor's Thesis in polymer and fiber technology, Lahti University of Applied Sciences, Finland (2018).

https://www.theseus.fi/bitstream/handle/10024/144444/Roininen_Timo.pdf?sequence=4\&isAllowed=y
} 


\subsection{Summary of PVC waste generation, collection and treatment in Finland}

The majority of PVC waste is post-consumer waste. There is no large scale separate collection of PVC waste and the majority of post-consumers waste ends up in mixed municipal waste, mixed C\&D waste, WEEE, ELVs and medical waste streams. The main treatment method for PVC waste in Finland is energy recovery and to a smaller extent landfilling. Domestic recycling takes place only at source, mainly for clean pre-consumer waste (treatment by-products) and some marginal quantities of separately collected clean pre-consumer waste are exported for recycling.

In Table 7, the available estimates and statistics regarding PVC waste generation, collection and treatment in Finland is listed. 
Table 7: Overview of PVC waste management in Finland

\begin{tabular}{|c|c|c|c|}
\hline Waste stream & Generation & Collection & Treatment \\
\hline PVC waste in total & $\begin{array}{l}\text { According to estimates/inter- } \\
\text { views: } \\
20-30 \text { kt post-consumers PVC } \\
\text { waste } \\
1-3 \text { kt pre-consumers PVC waste }\end{array}$ & & \\
\hline $\begin{array}{l}\text { Construction and } \\
\text { demolition waste } \\
\text { (C\&DW) }\end{array}$ & $\begin{array}{l}\text { No reliable estimates. According } \\
\text { to some preliminary results of an } \\
\text { ongoing study investigating plas- } \\
\text { tic streams (financed by Ministry } \\
\text { of Environment), the main plastic } \\
\text { streams in construction sector are } \\
\text { PVC and PE plastics }\end{array}$ & $\begin{array}{l}\text { Some separate collection for pipes } \\
\text { (mainly clean) and some bulky } \\
\text { waste, but in general PVC waste } \\
\text { from C\&DW stream go to land- } \\
\text { filling or incineration }\end{array}$ & $\begin{array}{l}\text { Separately collected } \\
\text { pipes are exported for } \\
\text { recycling (but minor } \\
\text { amounts) } \\
\text { Mixed waste inciner- } \\
\text { ated/landfilled, even } \\
\text { bulky waste inciner- } \\
\text { ated or landfilled }\end{array}$ \\
\hline WEEE and cables & Estimated at circa 100 t/year ${ }^{161}$ & $\begin{array}{l}\text { Gathered from specific waste } \\
\text { streams (e.g. from ELV disman- } \\
\text { tlers) }\end{array}$ & $\begin{array}{l}\text { Goes either to incin- } \\
\text { eration (after granula- } \\
\text { tion) or exported. }\end{array}$ \\
\hline ELVs & No reliable estimates & $\begin{array}{l}\text { Some dismantlers separate large } \\
\text { parts of plastics (e.g. bumpers), } \\
\text { but in general it goes to shredder } \\
\text { process and becomes SLF. } \\
\text { In total 50-70 kt of shredder light } \\
\text { fraction (SLF) is generated annu- } \\
\text { ally, which also includes PVC } \\
\text { waste } \\
\text { Circa 1.0-1.8 kt of PVC can be pre- } \\
\text { sent in SLF }\end{array}$ & $\begin{array}{l}\text { SLF goes to incinera- } \\
\text { tion }\end{array}$ \\
\hline Health care & No reliable estimates & No separate collection & $\begin{array}{l}\text { Incineration for hazar- } \\
\text { dous waste }\end{array}$ \\
\hline $\begin{array}{l}\text { Mixed MSW including } \\
\text { packaging waste }\end{array}$ & $\begin{array}{l}\text { Estimated at }<1 \% \text { of MSW (circa } \\
20-30 \mathrm{kt} / \mathrm{year})^{162}\end{array}$ & $\begin{array}{l}\text { No separate collection, PVC is not } \\
\text { accepted in the collection system } \\
\text { for packaging waste }\end{array}$ & $\begin{array}{l}\text { Circa } 11 \% \text { of MSW for } \\
\text { landfilling } \\
\text { Circa } 75 \% \text { to energy re- } \\
\text { covery }^{163}\end{array}$ \\
\hline
\end{tabular}

Note: For data source, see the text above.

${ }^{160}$ Vaajasaari K. (2018). Personal communication with Kati Vaajassari, Ministry of Environment.

${ }^{161}$ Marko Walavaara (2018). Personal communication with Marko Walavaara, Stena Recycling, (2018-09-03)

${ }^{162}$ In 2016 total MSW generation was 2,909 k-tonnes ( http://tilastokeskus.fi/til/jate/2016/jate_2016_2018-08-

31_tie_001_en.html)

163 http://www.stat.fi/til/jate/2016/jate_2016_2018-08-31_tau_002_en.html 


\section{PVC waste in Norway}

The Norwegian EPA develops regulations within the waste management sector and prepares guidelines for how the regulations should be followed. ${ }^{164}$ Current regulation in Norway differentiates between waste from households and waste generated by the business sector. Municipalities have the responsibility to ensure the collection and treatment of waste from households while companies have the obligation to ensure the collection and treatment of the waste they generate. Municipalities have adopted different solutions for the collection and treatment of household waste and the ratio between recycling, energy recovery and landfilling varies among municipalities.

In 2013, the Ministry of Climate and Environment in Norway published the strategy "From waste to resource"165 where increased recycling of plastic is one of the priority areas. In recent years, circular economy has gained a strong position in the public debate and on the political agenda in Norway. In 2018 the Norwegian Parliament voted that the Government should develop a national strategy for circular economy and set national targets for waste prevention, recycling and re-use in line with the EU Circular Economy Package. The focus of the Parliament's decision is set on waste from households (packaging) and plastic in the marine environment. ${ }^{166}$

PVC waste is not specifically mentioned in strategic documents and the project group's understanding is that this is not a priority area in Norway. Almost no information is available regarding PVC waste generation and treatment in Norway. According to interviews, this is because PVC as a material may not be as used in Norway as in the other Nordic countries and PVC products which have been used have not become waste yet. In addition, the separate collection and recycling of very small quantities of PVC waste in a country with a wide geographical spread gives low profitability. Therefore, PVC waste fractions are often collected and treated together with residual waste through energy recovery or are landfilled.

The overview presented in this analysis is rather fragmented, as no statistics on PVC waste are available and there is no follow-up of PVC waste in Norway. The research is mostly based on interviews and personal communication such as e-mails with different stakeholders in Norway.

\footnotetext{
164 http://www.miljodirektoratet.no/en/Areas-of-activity1/Waste/

165 Miljødepartementet (2013): Fra avfall til ressurs.

166 https://www.stortinget.no/no/Saker-og-publikasjoner/Saker/Sak/?p=67737 (September 2018)
} 


\subsection{Legislation}

Waste collection and treatment in Norway is regulated through:

- $\quad$ Regulation on protection against pollution and on waste (forurensningsloven) ${ }^{167}$

- Regulation on recycling and treatment of waste (avfallsforskriften) ${ }^{168}$

- Regulation on technical requirements for constructions (TEK17- Forskrift om tekniske krav til byggverk). ${ }^{169}$

There is no specific Norwegian regulation on how PVC waste should be collected and treated. The following requirements set by the above mentioned regulations influence how PVC waste is collected and treated in Norway.

Ban on landfilling of biodegradable waste: Norway implemented a ban on landfilling of biodegradable waste ${ }^{170}$ (waste with TOC over 10\%) in 2009 with the objective to reduce emissions of methane gas from landfills. ${ }^{171}$ Legally, it is still possible to landfill plastic waste such as PVC, but the ban on biodegradable waste has led to the majority of combustible waste being treated through energy recovery. This was also influenced by the fact that in 2010 the tax for waste treatment was lifted for energy recovery from waste, but it still applies for waste landfilling. This makes waste landfilling more expensive compared to energy recovery. ${ }^{172}$

Energy recovery from waste: Waste regulation does not set any target for energy recovery from waste, but it specifies that waste-to-energy plants should be planned, constructed and managed in a way that allows all the thermal energy generated through the incineration process to be used as long as it is practically possible. ${ }^{173}$

WEEE and ELVs: Targets for recycling of WEEE and ELVs are also set in the Regulation for waste management and recycling. Targets for recycling of WEEE vary between $75-85 \%$ depending on the product group, out of which $55-80 \%$ should be material recycling. For ELVs, the target is $95 \%$ recycling, out of which $85 \%$ should be material recycling. There is not specific target for recycling of the plastic fractions. ${ }^{174,175}$

\footnotetext{
167 https://lovdata.no/dokument/NL/lov/1981-03-13-6/KAPITTEL_5\#KAPITTEL_5

168 https://lovdata.no/dokument/SF/forskrift/2004-06-01-930

169 https://lovdata.no/dokument/SF/forskrift/2017-06-19-840

${ }^{170}$ Biodegradable waste is defined in the Regulation on recycling and treatment of waste as 'any waste that can undergo

anaerobic or aerobic degradation, such as food and garden waste, paper, cardboard and wood.

${ }^{171}$ https://lovdata.no/dokument/SF/forskrift/2004-06-01-930/KAPITTEL_9\#KAPITTEL_9

${ }^{172}$ Klima- og forurensningsdirektoratet (2013): Stortingsmelding om avfallspolitikken.

Økt utnyttelse av ressursene i plastavfall. http://www.miljodirektoratet.no/old/klif/publikasjoner/2956/ta2956.pdf

173 https://lovdata.no/dokument/SF/forskrift/2004-06-01-930/KAPITTEL_10\#KAPITTEL_10

174 https://lovdata.no/dokument/SF/forskrift/2004-06-01-930/KAPITTEL_4\#KAPITTEL_4

175 https://lovdata.no/dokument/SF/forskrift/2004-06-01-930/KAPITTEL_1\#KAPITTEL_1
} 
Construction and demolition waste: The Regulation on technical requirements for constructions requires:

"\$9-6. Development of a waste plan: the development of waste plans for construction projects over $300 \mathrm{~m}^{2}$ and demolition and rehabilitation projects over $100 \mathrm{~m}^{2}$.

\9-7. Mapping of hazardous waste and description of the neutralization method: the regulation requires the development of a mapping of hazardous waste in construction and demolition waste and information about how the hazardous waste was identified, results from analyses, amounts, how the waste will be removed, transported, etc.

$\int 9-8$. Waste selection: The regulation also requires that least 60 weight percent of the generated waste should be sorted in different waste types and delivered to approved waste management sites/ recycling stations. ${ }^{1776}$

No specific target is set for sorting of plastic fractions in this regulation. Even though plastic represents a very small weight percentage of the total amount of waste generated and it is not necessary to sort out plastic in order to reach the $60 \%$ target, it has been shown that the regulation has contributed to selective collection of waste including plastic, mainly plastic foil. ${ }^{177}$

During the 11th Meeting of Open-Ended Working Group of the Basel Convention in $2018,{ }^{178}$ the Government of Norway submitted a proposal to make plastic waste part of the list of wastes which are subject to trade controls under the Basel convention (the red list). If adopted, this amendment to the Basel convention could provide a better overview of the plastic waste flows to and from Norway, including PVC waste.

\subsection{Generation of PVC waste}

There are no systematic official statistics on PVC waste generation, collection or treatment in Norway. The Norwegian consulting company Mepex estimates that around 25,000 tonnes of PVC waste are generated annually in Norway. ${ }^{179}$

\subsection{Collection of PVC Waste}

There is no large-scale separate collection scheme for PVC waste in Norway.

\footnotetext{
176 https://lovdata.no/dokument/SF/forskrift/2017-06-19-840\#KAPITTEL_9

177 Klima- og forurensningsdirektoratet (2013): Stortingsmelding om avfallspolitikken.Økt utnyttelse av ressursene i plastavfall. http://www.miljodirektoratet.no/old/klif/publikasjoner/2956/ta2956.pdf

${ }_{178}$ http://www.basel.int/TheConvention/OpenendedWorkingGroup(OEWG)/Meetings/OEWG11/Overview/tabid/6258/Default.aspx (October 2018).

179 Sundt P. (2018). Personal communication with Peter Sundt, Senior Consultant, Mepex.
} 


\subsubsection{PVC in construction and demolition waste}

There are no official statistics to indicate the division between the different types of PVC waste. The Norwegian waste consulting company Mepex estimates that more than $50 \%$ of the PVC waste in Norway represents construction and demolition waste. ${ }^{180}$

\section{Hazardous waste}

PVC flooring, as well as e.g. roofing, folding walls and chair seats of soft PVC produced before the year 2000 are collected as hazardous waste in Norway due to the high probability for phthalates, asbestos, lead or PCB content. An extensive study done in 2010 by the consulting company Norconsult for the Norwegian EPA indicates that PVC wastes from rehabilitation or demolition of older buildings contain hazardous waste levels of one or more of these environmental contaminants. The study also indicates that PVC flooring is extensively used in older Norwegian buildings (built before 2000) and it concludes that due to the high probability of contamination (especially with high levels of phthalates like DEHP and BBP) it should be assumed that all PVC waste from buildings built before 2000 is hazardous waste and should be treated accordingly. ${ }^{181}$ This waste fraction should be reported to the Norwegian EPA with the Norwegian waste code 7156 Wastes containing phthalates (hazardous). ${ }^{182}$ In 2017, 4,500 tonnes of waste with phthalates were reported to the Norwegian EPA, the majority coming from demolition activities. The Norwegian EPA estimates that the majority of this fraction is soft PVC flooring. ${ }^{183}$ The hazardous waste limit for phthalates is $5,000 \mathrm{mg} / \mathrm{kg}$ for DEHP and DBP, and 2,500 mg/kg for BBP. ${ }^{184}$

The phthalates DEHP, BBP,DBP and DIBP, which are used as plasticisers (softeners) in PVC products, are listed on the Norwegian Priority List. ${ }^{185}$ This is a list of 33 chemicals or chemical groups assessed as health and environmental hazardous substances in Norway and which should be phased out or significantly reduced by the year $2020 .{ }^{186}$

Municipal waste recycling stations have limited resources to analyse the possible content of phthalates each time PVC waste from construction and demolition projects is delivered at recycling stations, therefore this is collected as hazardous waste. ${ }^{187,188,189}$

\footnotetext{
${ }^{180}$ Sundt P. (2018). Personal communication with Peter Sundt, Senior Consultant, Mepex.

${ }^{181} \mathrm{Klima}$ - og forurensningsdirektoratet (2010): Kartlegging av nyere fraksjoner av farlig avfall i bygg; http://www.miljodirektoratet.no/old/klif/publikasjoner/2613/ta2613.pdf

${ }^{182}$ Miljødirektoratet (2013): Farlig avfall fra bygg og anlegg;

http://www.miljodirektoratet.no/Documents/publikasjoner/M29/M29.pdf

${ }^{183}$ Larsen J. F. (2018). Personal communication with Jon Fonnlid Larsen, Senior Advisor, Norwegian EPA.

184 https://www.norskgjenvinning.no/tjenester/avfallstyper/farlig-avfall/avfall-med-ftalater/

185 http://www.miljodirektoratet.no/no/Tjenester-og-verktoy/Database/Kjemikalier/Prioritetslisten/

186 http://www.miljodirektoratet.no/no/Tjenester-og-verktoy/Veileder/Substitusjonsplikten/Om-prioritetslisten/

187 Denvik T. (2018). Personal communication with Trym Denvik, Director, Øvre Romerike Avfallsselskap IKS (ØRAS).

${ }^{188}$ Skogly E. (2018). Personal communication with Espen Skogly, Rådgiver Statistikk og nedstrømsløsninger, Sirkula IKS.

${ }^{189}$ Akselsen L. (2018). Personal communication with Line Akselsen, Driftsleder Skedsmo gjenvinningsstasjon, Romerike

Avfalsforedling IKS.
} 


\section{PVC Flooring}

Tarkett AS is a major producer and retailer of PVC flooring in Norway. The company puts on the Norwegian market more than 1 million $\mathrm{m}^{2}$ of PVC flooring each year. Tarkett AS provides take-back services for installation flooring waste from its own products. In 2017 the company collected 45.6 tonnes of PVC pre-consumer installation waste in Norway which was sent to Sweden to the company's sorting and recycling plant in Ronneby. The plant in Sweden collects PVC waste flooring from Sweden, Norway, Denmark and to a certain extent Germany and Poland. Around $75 \%$ of the collected PVC waste at the Ronneby plant is sorted out and recycled in new products at the company's manufacturing plant in Ronneby. ${ }^{190}$

\section{PVC Pipes}

The company Pipelife Norge AS produces PVC pipes in Norway. The company has produced 13,942 tonnes of PVC pipes in 2016 and 14,553 tonnes in 2017 for the Norwegian market. The PVC pre-consumer waste from pipe production was 218 tonnes in 2016 and 192 tonnes in 2017. The production waste from Pipelife is managed by the company Retura AS. ${ }^{191}$ This waste was previously landfilled, but according to Retura AS, since the middle of 2017 the waste is sent to the Baltic states for recycling. ${ }^{192}$

Post-consumer waste represented by PVC pipes is limited in Norway due to the fact that PVC pipes have only been used for relatively few years and most of them are still in use today. According to interviews, even if pipes are decommissioned they are left in the ground due to high excavation costs.

Roof foil and membranes

Protan AS is a major actor in this segment in Norway and several other countries. The company has a take-back system for its products, which are mostly made of soft PVC. Protan is a member of RoofCollect, a Europe-wide recycling system for thermoplastic membranes based in Germany. ${ }^{193}$ Post-consumer PVC waste that Protan takes back from its customers is sent to RoofCollect for recycling. ${ }^{194}$

\subsubsection{WEEE and cables}

PVC cables represent the second biggest PVC waste stream in Norway according to estimates. ${ }^{195}$ Cables are collected as WEEE. Norwegian Waste Regulation requires producers and importers of EE equipment to join a collectively financed take-back company. There are three different take-back companies in Norway authorized by the Norwegian EPA:

\footnotetext{
${ }^{190}$ Aar T. (2018). Personal communication with Thomas Aar, Key Account Manager, Tarkett AS.

${ }^{191}$ Kvendset G. A. (2018). Personal communication with Geir Atle Kvendset, HSE and Quality manager, Pipelife Norge.

192 Tronvold J. (2018). Personal communication with Jon Tronvold, Retura AS.

193 http://roofcollect.com/

194 Elstad L: A. (2018). Personal communication with Lars Aksel Elstad, HSE/QA Manager Production, Protan AS.

195 Sundt P. (2018). Personal communication with Peter Sundt, Senior Consultant, Mepex, September 2018.
} 
- ERP Norway AS

- Norsirk AS

- Renas AS

All three companies report quantities of collected WEEE in the national EE-registry owned by the Norwegian EPA. In 2017, the three take-back companies reported a total of 143,610 tonnes of collected WEEE, out of which 19,130 tonnes are represented by cables and wires. ${ }^{196}$

Renas AS is the one out of the three companies which collect the majority of cables and wires in Norway. ${ }^{197}$ The company further sells the cables to recycling companies including Stena Recycling, KMT Gjennvining and Metallco. ${ }^{198}$

\subsubsection{End-of-life vehicles}

Autoretur AS is the national take-back system for EVLs in Norway. The company is responsible for ensuring collection and recycling of ELVs. In 2017, Autoretur collected 143,664 EVLs in Norway. Hazardous components and tires are first dismantled from ELVs before these are sent to shredding plants. ELVs from Norway are shredded in ten shredding plants (eight in Norway, one in Denmark and one in Sweden). Each ELV which is sent to shredding weights on average $1,088 \mathrm{~kg}$ which means that 156,301 tonnes of ELVs where shredded in 2017. Four different fractions result from the shredding process: magnetic metal, non-magnetic metal, shredder light fraction (SLF) and other. SLF is formed of, among other fractions, glass, textiles, plastics and adhesive. In 2017, each ELV generated on average $189 \mathrm{~kg}$ of SLF in Norway, which means a total of 27,152 tonnes of SLF produced at national level. In 2017 , 35\% of SLF was sent to energy recovery (down from $53 \%$ in 2016), $49 \%$ to material recovery (an increase from $35 \%$ in 2016) and $16 \%$ was landfilled (an increase from $12 \%$ in 2016). ${ }^{199}$

According to Autoretur, there are around 40 plastic types in a vehicle and they represent around $10 \%$ of the vehicle's weight and $50 \%$ of the volume. No information was found on how much PVC Autoretur collects from ELVs. Some of the plastics in the SLF are separated at Stena Recycling in Halmstad, Sweden and sent for recycling to Galoo ${ }^{200}$, a recycling company which owns two plants in the Netherlands and Belgium specialized on plastic recycling from SLF. ${ }^{201}$

If it is assumed that all 143,664 EVLs collected vehicles will go to shredding and that $2-3 \%$ of the shredded vehicles consist of PVC, ${ }^{202}$ a total of 3,100 tonnes ${ }^{203}$ of PVC from ELVs end up in the shredder waste.

\footnotetext{
${ }^{196}$ EE-registret(2017): Årsrapport 2017 http://www.eeregisteret.no/file/Årsrapport\%202017.pdf

197 EE-registret(2017): Årsrapport 2017 http://www.eeregisteret.no/file/Årsrapport\%202017.pdf

${ }^{198}$ Dordipour O. (2018). Personal communication with Oktay Dordipour, Technical Manager, Renas AS.

199 Autoretur (2017): Miljøregnskap 2017.

200 https://www.autoretur.no/plasten-blir-til-noe-nytt/ (october 2018).

${ }^{201}$ Autoretur (2017): Miljøregnskap 2017.

${ }^{202}$ Cullbrand, K (2018). Personal communication with Klas Cullbrand, Chalmers Industriteknik.

${ }^{203}$ Based on a weight of an ELV of 1,088kg (see above).
} 


\subsubsection{Health care}

No statistics are available for the amount of PVC waste generated or collected from the Norwegian health care sector. According to interviews, PVC waste is not subject to separate collection and is likely to be sent to energy recovery together with mixed waste fractions. It seems that separate collection of PVC waste has not been implemented due to the fear of possible contamination with hazardous substances.

\subsubsection{Packaging}

Grønt Punkt Norge AS operates a producer responsibility take-back system for packaging in Norway. Members of Grønt Punkt Norge AS are responsible for $85 \%$ of the total packaging that enters the Norwegian market. In 2017, the company collected 119,105 tonnes of plastic packaging. Recycling represented $44.5 \%$, while energy recovery represented $52.7 \%{ }^{204}$ There is no overview available over how much PVC waste is part of the packaging waste collected by Grønt Punkt in Norway. At the point of this study, the company was carrying out an analysis on PVC fractions in packaging and how this is treated. ${ }^{205}$

\subsubsection{Other PVC waste}

Other types of PVC waste are collected on some municipal recycling stations as either hard plastic together with other types of plastic, ${ }^{206,207}$ or as waste for incineration. ${ }^{208,209}$ No information is available regarding how much PVC waste is collected this way.

\subsection{Treatment}

\subsubsection{Recycling}

No overview of PVC recycling exists in Norway. There are examples of companies which send their pre-consumer PVC waste to recycling (Pipelife and Tarkett). The recycling of PVC is done outside of Norway in e.g. Sweden or the Baltic states.

Based on data reported in the EE-registry, 19,095 tonnes of cables and wires were collected as WEEE and treated in 2017 . Recycling represented $65.47 \%$ of the treatment. ${ }^{210}$ The yearly reports from the EE-registry do not provide information on the

\footnotetext{
204 https://www.grontpunkt.no/om-oss/fakta-og-tall/ (october 2018).

${ }^{205}$ Nesheim S. K. (2018). Personal communication with Sjur Kvifte Nesheim, Analyst, Grønt Punkt Norge AS

${ }^{206}$ Denvik T. (2018). Personal communication with Trym Denvik, Director, Øvre Romerike Avfallsselskap IKS (ØRAS).

${ }^{207}$ Skogly E. S. (2018). Personal communication with Espen Skogly, Rådgiver Statistikk og nedstrømsløsninger, Sirkula IKS.

${ }^{208}$ Halaas E. Th. (2018). Personal communication with Ellen Thomsen Halaas, Section Manager, Waste Management Agency of the City of Oslo.

${ }^{209}$ AkselsenL. (2018). Personal communication with Line Akselsen, Driftsleder Skedsmo gjenvinningsstasjon, Romerike Avfalsforedling IKS.

${ }^{210}$ EE-registret(2017): Årsrapport 2017. http://www.eeregisteret.no/file/Årsrapport\%202017.pdf
} 
amount of PVC waste in the collected cables. For example, Stena Recycling Norway sends the collected PVC cables to the Stena Recycling cable granulation plant in Töva-Sundvall, Sweden. In 2017, the plant received goo tonnes of PVC cables from Norway. Metals are extracted from the cables for recycling, while the PVC is sold to Ragn-Sells in Sweden, who stores it. ${ }^{211}$

PVC waste is also collected as hard plastic on some municipal waste recycling stations in Norway, but there is no information about how much of the collected plastic that is PVC waste. It is therefore very difficult to estimate how much of it that is recycled.

\subsubsection{Energy recovery}

There are 18 waste incineration plants in Norway ${ }^{212}$ and in $2017,1,683,000$ tonnes of waste were incinerated, out of which 1,317,000 tonnes with energy recovery. ${ }^{213}$ There are no statistics available on the amount of PVC waste entering the waste-to-energy facilities in Norway together with residual waste.

The PVC waste collected as hazardous waste is treated in a few specialized incineration plants in Norway. ${ }^{214}$

\subsubsection{Landfilling}

Some fractions of PVC waste can be found in e.g. mixed construction and demolition waste. Since it is difficult for some waste management companies to separate the different fractions from construction and demolition waste, it also happens that PVC waste in mixed construction and demolition waste is landfilled. No information is available on the amounts of PVC waste that is landfilled. ${ }^{215}$

\subsection{Summary of PVC waste generation, collection and treatment in Norway}

In Table 8, the available estimates and statistics regarding PVC waste generation, collection and treatment in Norway are listed (numbers for 2017)

\footnotetext{
${ }^{211}$ Mårell M. (2018). Personal communication with Marcus Mårell, Production Manager, Stena Recycling Töva-Sundvall, Sweden.

212 https://www.avfallnorge.no/fagomraader-og-faggrupper/energigjenvinning

213 https://www.ssb.no/natur-og-miljo/statistikker/avfhand

${ }^{214}$ Lindstad M. (2018). Personal communication with Marit Lindstad, Norwegian Association for Hazardous Waste (NFFA).

${ }^{215}$ Eriksen F. (2018): Personal communication with Frode Eriksen, Nedstrømskoordinator, Franzefoss Gjenvinning AS.
} 
Table 8: Overview of PVC management in Norway

\begin{tabular}{|c|c|c|c|}
\hline Waste stream & Generation & Collection & Treatment \\
\hline PVC waste in total & $\begin{array}{l}25 \text { kt of PVC } \\
\text { annually }\end{array}$ & & \\
\hline $\begin{array}{l}\text { Construction and demolition } \\
\text { waste (C\&DW) }\end{array}$ & $\begin{array}{l}50 \% \text { of all PVC waste } \\
\text { generated in Norway } 216\end{array}$ & $\begin{array}{l}\text { Pre-consumer waste recycled } \\
\text { RoofCollect (Germany) } \\
\text { Mixed with other C\&DW }\end{array}$ & $\begin{array}{l}\text { Recycling (in Norway, Germany } \\
\text { and the Baltics) } \\
\text { Incineration - together with resid- } \\
\text { val waste } \\
\text { Landfilling }\end{array}$ \\
\hline WEEE and cables & $\begin{array}{l}19.1 \mathrm{kt} \text { of cables and } \\
\text { wires }\end{array}$ & $\begin{array}{l}\text { Three producer-responsibility } \\
\text { schemes, RENAS AS is the big- } \\
\text { gest on cables and wires }\end{array}$ & Deposited (after granulation) \\
\hline ELVs & No reliable estimates & $\begin{array}{l}27.1 \text { kt of SLF which also in- } \\
\text { cludes PVC waste } \\
\text { Circa } 3.1 \text { kt of PVC can be pre- } \\
\text { sent in SLF }\end{array}$ & $\begin{array}{l}35 \% \text { of SLF energy recovery } \\
49 \% \text { to material recovery } \\
16 \% \text { was landfilled }\end{array}$ \\
\hline Health care & $\begin{array}{l}\text { No reliable } \\
\text { estimates }\end{array}$ & No separate collection & Incineration for hazardous waste \\
\hline $\begin{array}{l}\text { Mixed MSW including pack- } \\
\text { aging waste }\end{array}$ & & $\begin{array}{l}\text { On municipal waste recycling } \\
\text { stations, PVC-waste is either } \\
\text { collected as } 1 \text { ) hazardous } \\
\text { (mostly old flooring); } 2 \text { )as part } \\
\text { of the hard plastic waste or 3)as } \\
\text { waste for incineration }\end{array}$ & $\begin{array}{l}\text { In } 2017,1.683 \text { kt of waste was in- } \\
\text { cinerated in Norway } \\
\text { Some recycling of the mixed hard } \\
\text { waste plastic, but no reliable esti- } \\
\text { mates are available. Grønt Punkt } \\
\text { Norge AS is currently carrying out } \\
\text { an analysis on PVC waste from } \\
\text { packaging }\end{array}$ \\
\hline
\end{tabular}

Note: For data source, see the text above.

${ }^{216}$ Sundt P. (2018). Personal communication with Peter Sundt, Senior Consultant, Mepex. 


\section{PVC waste in Sweden}

Collection and treatment of PVC waste is not compiled and followed-up by any national statistics in Sweden.

\subsection{Legislation}

Waste collection and treatment in Sweden is regulated through chapter 15 in the environmental code, as well as in several ordinances, primarily in Ordinance (2011:927) on waste. PVC waste is not mentioned specifically in either the environmental code or in the waste ordinance, and no national targets focus on PVC waste in particular. Other legal documents regulating waste streams where PVC waste might be present are:

- Ordinance (2014:1073) on packaging and packaging waste

- Ordinance (2014:1075) on electric and electronic equipment

- Ordinance (2007:1085) on vehicles

- Ordinance (2013:253) on incineration of hazardous waste

- Ordinance (2013:253) on incineration of waste

- Ordinance (2001:512) on landfill of waste

PVC waste is not brought up specifically in the national waste management plan or in other national strategies regarding waste.

\subsection{Generation of PVC waste}

Similar to the other Nordic countries, the total amount of generated PVC waste relies on estimates. Breaking down the estimated total generation of PVC waste in the EU per capita (roughly $5 \mathrm{~kg}$ per inhabitant) it would result in a total amount of PVC waste of around 51,000 tonnes. ${ }^{217}$

${ }^{217}$ Population of Sweden: 10196177 in August 2018. Statistics Sweden (2018). : https://www.scb.se/hitta-statistik/statistikefter-amne/befolkning/befolkningens-sammansattning/befolkningsstatistik/ 


\subsection{Collection of PVC waste}

The impression of the project group when contacting private waste companies in Sweden is that collection of PVC waste does not represent a big part of their business, if any. If they are offered to collect and find a recycling outlet for separately collected PVC waste, preferably as homogenous as possible (e.g. pipes), there are often market possibilities for it, especially abroad, but the waste companies are not seeking opportunities actively.

\subsubsection{PVC in C\&DW}

In Sweden, there is no available statistics on the amount of PVC waste present in construction and demolition waste. According to the official waste statistics, around 60,000 tonnes of plastic waste were generated in the sector in $2016,{ }^{218}$ but the share of PVC is unknown. There is no formal collection system for plastic waste from construction sites in Sweden. However, different kinds of plastic waste, e.g. PVC waste, may exist on a business-to-business level. There are also two collection systems for building products in Sweden; one for pipes and one for plastic flooring initiated by the plastic pipe and flooring industry. The two collection systems are described in more detail below.

\subsubsection{Collection of pipes by The Nordic Pipe Association}

About 5,000 tonnes of installation waste from plastic pipes are generated annually in Sweden. In addition, an unknown amount of pipe waste from both construction and demolition is produced each year, which most likely ends up in mixed waste fractions that go to energy recovery. Plastic pipes in demolition waste are estimated to consist of PVC pipes to over $70 \%$, but pre-consumer pipe waste from installation of pipes is mainly consisting of HDPE and PP. ${ }^{219}$

The Nordic Pipe Association's collection system is targeted at both collection of waste from installation of plastic pipes as well as on old pipes from demolition. Pipe waste from PipeLife, Uponor and Wavin are collected upon request on seven locations in Sweden. Around 100 tonnes per year are collected within the system. ${ }^{220}$ The collected pipe waste is transported to Swerec AB in Lanna, Sweden. On behalf of The Nordic Pipe Association Swerec sorts, washes and tries to find recycling markets for the collected PVC. Swerec estimates that $60-80 \%$ of the received amounts are sent to recycling due to incorrectly sorted material, and the rest is recovered for energy. Not only PVC pipes are collected, but also pipes made out of HDPE and PP. According to Swerec around $30 \%$ of the received amounts of pipe waste from the Nordic Pipe Association consists of PVC, but it can vary to a high extent between containers. The sorted PVC fraction is recycled abroad, if a recycling outlet can be found. ${ }^{221}$

\footnotetext{
${ }^{218}$ Naturvårdsverket (2018). Statistikdatabasen.

${ }^{219}$ Boss, A (2018). Personal communication with Annika Boss, Swerea IVF.

${ }^{220}$ Ahlm (2018).

${ }^{221}$ Krantz, A (2018). Personal communication with Anders Krantz, Swerec AB.
} 


\subsubsection{Collection of PVC flooring by The Swedish Flooring Trade Association}

The Swedish Flooring Trade Association sold around 6.4 million $\mathrm{m}^{2}$ plastic flooring in Sweden in 2017, representing 18,000-20,000 tonnes per year of which 90-95\% is PVC flooring. ${ }^{222}$ Up to $10 \%$ of installation waste can be generated when flooring is installed, i.e. 1,800-2,000 tonnes annually. ${ }^{223}$

Tarkett $A B$ is operating a collection system for installation flooring waste on behalf of The Swedish Flooring Trade Association. The installation waste is separated on-site based on flooring manufacturer and is transported to Tarkett's recycling facility in Ronneby. Most of the installation waste is generated from installation of Tarkett's PVC flooring, and is recycled to new flooring. Tarkett $A B$ is currently the only flooring manufacturer within The Swedish Flooring Trade Organisation who recycles their collected installation waste. In 2017, 325 tonnes of installation waste were collected in Sweden of which 250 tonnes belonged to Tarkett. Commonly, up to $25 \%$ of the collected installation waste consists of other waste than flooring or old flooring waste including glue and contaminants, and is therefore sent to energy recovery. ${ }^{224}$ Considering the total amount of installation waste from PVC flooring it becomes evident that the main part is not separately sorted, but ends up in mixed waste fractions to energy recovery.

Despite initiatives to increase recycling of PVC waste within construction and demolition waste, the majority of the PVC waste is sent to energy recovery in mixed waste fractions. ${ }^{225}$

\subsubsection{WEEE and cable waste}

163,000 tonnes of WEEE were collected within the producer responsibility for EEE of which 136,000 tonnes were sent to recycling. ${ }^{226}$ There are no statistics on the amount of plastics in WEEE, but estimates suggest around 20 weight percent, ${ }^{227}$ meaning that the collected amounts included around 30,000 tonnes of plastics. PVC is not a main plastic type and the overall percentage is not known.

PVC present in shredder residues from shredding of WEEE is limited. According to European Electronics Recyclers Association (EERA) the content of PVC in WEEE shredder residues is around one weight percent. ${ }^{228}$

\footnotetext{
222 Duberg, D (2018). Personal communication with Dag Duberg, Tarkett AB.

223 Golvbranschen (2018). https://www.golvbranschen.se/miljo-hallbarhet/golvatervinning/

224 Duberg, D (2018). Personal communication with Dag Duberg, Tarkett AB.

225 Elander, M and Sundqvist J-O (2015). Potentialer för materialåtervinning av byggplast från rivning. Erfarenheter utifrån två fallstudier. IVL Report.

226 The Swedish EPA (2018). Avfall i Sverige 2016.

${ }^{227}$ Baxter et al. (2014). Plastic value chains, Case: WEEE (Waste Electric and electronic equipment) in the Nordic region.

TemaNord 2014:542

${ }^{228}$ EERA (2017). EERA's comments and proposals for the EU Plastics Strategy 2017. Swerea IVF and Stena Metall.
} 


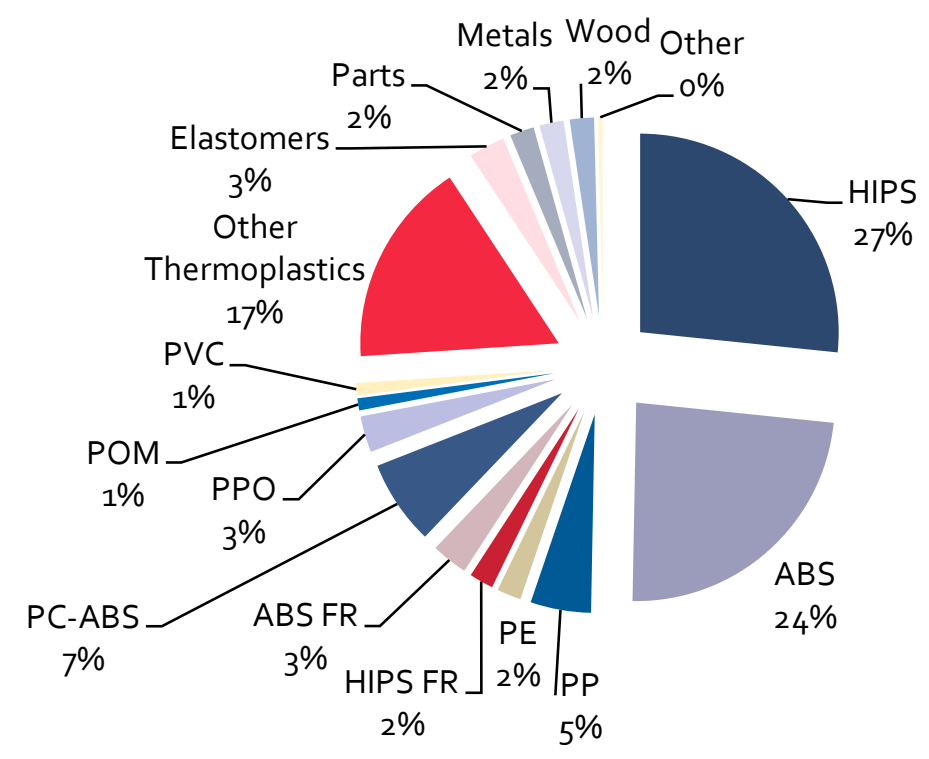

Source

EERA (2017). EERA's comments and proposals for the EU Plastics Strategy 2017. Swerea IVF and Stena Metall.

PVC from WEEE is generally not recycled, but sent to energy recovery.

Cable waste has an economic value due to its copper and aluminium content. Cables are to a high extent dismantled from collected WEEE, and send to separate recycling in the form of cable granulation as it creates higher economic value than letting the cables stay on the WEEE product and go into a shredding process. Dismantlers of WEEE often remove specifically larger cables for that reason. The amount of cable waste from WEEE is thus small compared to the amounts of separately collected cable waste in Sweden. It is estimated that $40,000-45,000$ tonnes of cable waste are separately collected every year, of which $70 \%$ is PVC cable. The amount includes both post-consumer cable waste and production waste from cable manufacturing. The main part of the cable waste comes from old buildings. Half of the cables manufactured in Sweden are produced from PVC. Using cross-linked PE instead of PVC is getting more common. ${ }^{22}$

The metals in cable waste are extracted through cable granulation, which has been performed in Sweden since 1973. After pre-sorting, the cable waste is chopped and granulated twice before the metal can be separated from the plastic in a fluid bed. The aim of the pre-sorting step is to separate different kinds of cables into for example long cable sections, type of insulation, conductor diameter, plated or un-plated conductors and copper and aluminium cables. The plastic fraction, mostly containing PVC, has traditionally been sent to energy recovery in general. The PlastSep process is a technique used by the

${ }^{229}$ Belleza, E and Youhanan, L (2017). Rätt sak till rätt behandling - materialåtervinning, avfallsförbränning och detoxifiering av samhället. IVL Report B2278. 
cable recyclers to separate different plastics from each other using gravimetric separation in water. Plastics with a relatively low density float whereas plastics with a higher density, such as PVC, sink. The PlastSep process generates a lighter, polyolefin fraction, a heavier "PVC fraction" and further separates metals from plastics, recovering more metals from the cable waste and purifying the plastic fractions. ${ }^{230}$

Stena Recycling AB has the PlastSep process installed at their facilities in Kalmar and Sundsvall. Stena Recycling is the only Swedish actor that is authorised to put recyclates including DEHP on the European market (see Chapter 2.4.2). DEHP in PVC from post-consumer cable waste can be rather high: $6-7 \%$ in PVC from post-consumer copper cables, and $5-7 \%$ in PVC from aluminium cables. ${ }^{231}$

Due to the presence of DEHP in post-consumer cable waste, it is assumed that other actors granulating cables are sending the plastic fraction including PVC to energy recovery. Export of cable waste is also an option, but the amounts cannot be estimated.

\subsubsection{End-of-life vehicles}

ELVs with a total weight of 3.5 tonnes are collected and dismantled in the Nordic countries according to Directive 2000/53/EG on end-of-life vehicles. ELVs are dismantled of hazardous components and emptied of fluids. Components are also dismantled for reuse purposes to a varying extent. What remains after the dismantling procedure is sent to shredding with focus on extracting bulk metals such as iron and steel, copper and aluminium. Plastics are generally ending up in the so-called shredder light fraction, which is either sent to energy recovery or to landfill. ${ }^{232}$

Roughly estimated, discarded ELVs consist of around 2-3\% of PVC each. ${ }^{233}$ The total number of discarded ELVs in 2017 was 193,013 in Sweden ${ }^{234}$, which would represent an amount of PVC of between 3,090-5,200 tonnes per year. ${ }^{235}$

Cables from end-of-life vehicles are generally not dismantled, even though it is becoming more common to remove the easily available cables. Some car dismantlers in Sweden have started to carry out dismantling using machines with different tools in order to dismantle some valuable car components. By using such a machine, cables can also be dismantled more easily. The total amount of dismantled cables from ELVs is not known, and neither is whether or not the PVC in the cables is subject to energy recovery or recycling. ${ }^{236}$

\footnotetext{
${ }^{230}$ Rasmussen E and Boss A (2007). PlastSep - A new technology for sorting and recycling of cable polymers.

${ }^{231}$ Boss, A (2014). Recycling of electrical cables - With focus on mechanical recycling of polymers. Swerea IVF-Report Public, 21813. Average of two months production at Stena Recycling in Sundsvall during 2012-2013.

${ }^{232}$ Stenmarck, Å (2017). Hazardous substances in plastics. Nordic Council of Ministers.

${ }^{233}$ Cullbrand, K (2018). Personal communication with Klas Cullbrand, Chalmers Industriteknik.

234 SBR (2018). http://www.sbrservice.se/branschinformation/statistik-total/

${ }^{235}$ Assuming that an average ELV to shredding weights $800-900 \mathrm{~kg}$. Abraham, M (2018). Personal communication with Michael Abraham, Sveriges Bilåtervinnares Riksförbund.

${ }^{236}$ Belleza, E and Youhanan, L (2017). Rätt sak till rätt behandling - materialåtervinning, avfallsförbränning och detoxifie-

ring av samhället. IVL Report B2278.
} 


\subsubsection{Health care}

There are neither any reliable statistics on the total amount PVC waste generated from the health care sector in Sweden, nor estimates of the total amount of plastic waste. There are, however, national figures on the amount of source-separated plastic waste sent to recycling, mainly consisting of packaging waste and products that have not been in contact with patients. The share of PVC in this source-separated plastic fraction is considered very limited, and it is unlikely that it is recycled in the end as PVC in plastic packaging waste is generally not recycled. The focus is instead on polyolefins. It is estimated that around 80 tonnes of PVC blood containers are generated annually within the Swedish health care sector, and are sent to energy recovery. ${ }^{237}$ Some PVC waste, depending on how it has been used and the level of contamination, can be sent as a part of other hazardous waste from the health care sector and incinerated at $1100^{\circ} \mathrm{C}$.

\subsubsection{Packaging}

Plastic packaging is subject to producer responsibility obligations through Ordinance (2014:1073) on producer responsibility for packaging and packaging waste. Plastic packaging waste from households is either separately collected by kerbside collection or by public recycling stations. The collected plastic packaging waste is manually and automatically sorted into its dominating plastic types, PE, PP and PET (sometimes also PS). The major collection system operated by Förpacknings- och tidningsinsamlingen $A B(F T I)$ has contracts with Swerec in Sweden, and three German sorting facilities. FTI is, however, investing in a new facility planned to go into operation in 2019 in Motala. PVC packaging waste collected from households are not separated and thus becomes reject and sent to energy recovery in waste-to-energy plants or in the cement industry. Commercial plastic packaging waste is collected on a businessto-business level. In 2016, 212,500 tonnes of plastic packaging were put on the Swedish market and 99,700 tonnes of plastic packaging were sent to recycling ${ }^{238}$, but the share of PVC packaging waste is unknown.

FTI has carried out two waste analyses of source-separated plastic packaging waste from households, both from public recycling stations and from the residual waste-toenergy recovery. The two analyses, which cannot be seen as representative as they are too few, showed that the category "other plastics", including PVC packaging and other types of packaging, constituted 6 weight percent, which indicates that the amount of $\mathrm{PVC}$ packaging waste among consumer plastic packaging waste is minor. ${ }^{239}$

\footnotetext{
${ }^{237}$ Stenmarck et al. (2018). Ökad plaståtervinning - potential för utvalda produktgrupper. The Swedish EPA: Report 6844

${ }^{238}$ Naturvårdsverket (2017). Sveriges återvinning av förpackningar och tidningar 2016.

${ }^{239}$ Stenmarck, Å et al. (2018). Ökad plaståtervinning - potential för utvalda produktgrupper. Report 6844. The Swedish EPA.
} 


\subsubsection{Other PVC waste}

Separate collection of mixed plastic waste for recycling occurs at several manned municipal recycling centrals in Sweden. The collection is a result of the municipalities' own initiative to increase recycling of waste and increase the service level for their inhabitants. The fraction might consist of rigid plastic products such as buckets, trays, garden furniture, toys and pipes. Slightly more than 7,000 tonnes of plastic waste were collected at manned municipal recycling centres in Sweden in 2015. Most of the plastic waste fraction is sent to Swerec AB for recycling. They accepted around 4,000 tonnes of this type of plastic waste in 2016 from around 20 municipalities. Many of these municipalities do not, however, instruct PVC waste to this fraction, but instead to mixed combustible waste fractions as the most valued plastics found in this plastic fraction is rigid PP and PE. According to waste analyses on separately collected plastic waste from two recycling centres in Sweden, PVC in average represents 7 weight percent of the analysed amounts. This is, however, only indicative and based on too few analyses to be scaled up on a larger level. ${ }^{240}$

On 1 November Van Werven will start up business in Borås, Sweden. They will accept mixed rigid plastics. They will establish a sorting line in Borås and sort the plastic waste manually, and send the PVC to the Netherlands where it will be further recycled.

\subsection{Treatment}

\subsubsection{Recycling}

Recycling of PVC waste exists in Sweden, but to an unknown extent as there is no systematic follow-up on the amount. One example of recycling of pre-consumer PVC waste is Tarkett's facility in Ronneby, where plastic flooring is recycled. Stena Recycling recycles PVC waste from cable waste at two facilities. Business-to-business flows of PVC waste exist, but do not represent a big part of the private waste management companies' business according to interviews. The project group's evaluation is that most recycling of Swedish PVC waste takes place abroad.

\subsubsection{Energy recovery}

There are no statistics on the amount of PVC waste entering waste-to-energy facilities in Sweden. In 2017, 2.4 million tonnes of household waste were recovered for energy in Sweden at 34 waste-to-energy plants incinerating household waste. 3.7 million tonnes of other waste were recovered for energy at the same facilities. Energy recovery of waste takes place at other facilities than the ones accepting household

\footnotetext{
${ }^{240}$ Fråne et al. (2017). Materialåtervinning av plastavfall från återvinningscentraler. IVL Report C245.
} 
waste. There are, however, no complete statistics on the total amount of waste-toenergy recovery in Sweden. ${ }^{241}$

Hazardous waste with a content of organic halogens exceeding $1 \%$, expressed as chlorine, must be disposed of at a temperature of at least $1100^{\circ} \mathrm{C}$ according to Ordinance (2013:253) on incineration of waste. This is likely to be the case for monostreams of PVC waste as the PVC itself contains $57 \%$ chlorine. The issue is whether PVC waste is classified as hazardous waste or not. In Appendix 4 in the Swedish waste ordinance, plastic waste with a content of hazardous substances or contaminated with hazardous substances according to $\int 13 \mathrm{~b}$ shall be regarded as hazardous waste. $\S 13$ b states that Appendix III to the waste framework directive (2008/98/EG) shall be applied to evaluate whether the waste has hazardous properties according to Council Regulation (EC) No 440/2008. As an example, the phthalate DEHP has a harmonised classification according to Annex VI of Regulation (EC) No 1272/2008 (CLP Regulation) of hazard class "Repr. $1 \mathrm{~B}^{\mathrm{B}}$ and hazard statement $\mathrm{H}_{3} 60$. According to Regulation (EU) No $1357 / 2014^{242}$, which replaces Annex III to the waste framework directive, waste with a substance classified with hazard class "Repr. 1B" and hazard statement $\mathrm{H}_{3} 6 \mathrm{O}$ with a concentration that equals or exceeds $0.3 \%$ shall be classified as hazardous according to HP 10: Toxic for reproduction. In this example, it means in short that waste with a concentration of DEHP that equals or exceeds $0.3 \%$ shall be classified as hazardous waste.

There is, in other words, a possibility to classify certain PVC waste fractions as hazardous waste depending on their content of hazardous substances. To which extent this is applied is not known, and neither is the amount of PVC waste that is incinerated as hazardous waste at a temperature of at least $1100^{\circ} \mathrm{C}$. Instead, most PVC waste is not recovered for energy as non-hazardous waste, but together with other types of waste in mixed combustible waste fractions. The waste-to-energy sector is reluctant to accept mono-streams of PVC waste-to-energy recovery, primarily as the chlorine may cause corrosion in the flue gas cleaning system. This can be prevented by mixing the PVC waste with other waste types. For energy recovery of SLF a study from 2015 concluded that there is a risk of issues with corrosion if the content of SLF exceeds $29 \%$ in the fuel mix. ${ }^{243}$

\subsubsection{Landfilling}

Sweden has implemented bans on landfilling sorted combustible waste (since 2002) and organic waste (since 2005), which is stated in Ordinance (2001:512) on landfilling of waste. There are two exceptions to the bans; one is that waste with a homogenous composition with less than 10 weight percent of TOC (Total Organic Carbon) may be

\footnotetext{
${ }^{241}$ Avfall Sverige (2018). Svensk avfallshantering 2018.

${ }^{242}$ COMMISSION REGULATION (EU) No 1357/2014 of 18 December 2014 replacing Annex III to Directive 2008/98/EC of the European Parliament and of the Council on waste and repealing certain Directives.

${ }^{243}$ Stålenheim, A et al. (2015). Korrosion och beläggningsbildning vid förbränning av bränslet SLF. Energiforsk Report 2015:197.
} 
landfilled, and the other stipulates that heterogeneous waste with less than 10 volume percent combustible waste can also be subject to landfilling. These exceptions are listed in the regulations on treatment of combustible waste and organic waste from the Swedish EPA. ${ }^{244}$

Despite the bans, landfilling of combustible and organic waste may also be granted exemptions if there is lack of capacity in the region other than for landfilling the waste. This is according to $\ 13$ in the Ordinance on landfilling of waste. The exemption is granted by the supervisory authority, and received by the landfill owner. There are also possibilities to landfill combustible or organic waste under special circumstances. The exemptions are granted by the Swedish county councils. The rules for exemptions from the bans are also described in the regulations on treatment of combustible waste and organic waste from the Swedish EPA.

PVC waste is due to the landfill bans generally not subject to landfilling, but can, as mentioned above, be landfilled due to granted exemptions. Compiled statistics of the total amount of PVC waste landfilled due to exemptions are not available. However, several Swedish landfill owners witness that they have exemptions for landfilling PVC, and examples of exemptions can quite easily be identified. In 2017 Dåva Deponi \& Avfallscenter in Umeå landfilled around 47 tonnes of PVC waste from construction and demolition, mainly pipe waste, on granted exemption from the county council in Västerbotten. The reason is the lack of capacity for recycling or energy recovery within reasonable transport distance. ${ }^{245}$ There is a waste-to-energy plant in Umeå, but incineration of PVC waste causes corrosion in the flue gas cleaning system. The need for landfilling PVC waste remains in 2018. ${ }^{246}$ Another example is Högbytorp landfill outside of Stockholm, owned by Ragn-Sells, which has an exemption for landfilling PVC amounts of 800 tonnes per year. This exemption was, however, not used in 2017 .

\footnotetext{
${ }^{244}$ Naturvårdsverkets föreskrifter NFS 2004:4 och allmänna råd om hantering av brännbart avfall och organiskt avfall. 245 Länsstyrelsen Västerbotten (2018). Dispens från förbud mot deponering av organiskt avfall vid Dåva deponi och avfallscenter i Umeå kommun.

${ }^{246}$ Sjölund, G (2018). Personal communication with Gustaf Sjölund, Dåva Deponi \& Avfallscenter.
} 


\subsection{Summary of PVC waste generation, collection and treatment in Sweden}

In Table 9, the available estimates and statistics regarding PVC waste generation, collection and treatment in Sweden is listed.

Table 9: Overview of PVC waste management in Sweden

\begin{tabular}{|c|c|c|c|}
\hline Waste stream & Generation & Collection & Treatment \\
\hline PVC waste in total & No reliable estimates & $\begin{array}{l}\text { No systematic statistics or re- } \\
\text { liable estimates }\end{array}$ & $\begin{array}{l}\text { No systematic statistics or reliable } \\
\text { estimates }\end{array}$ \\
\hline $\begin{array}{l}\text { PVC in construction } \\
\text { and demolition waste }\end{array}$ & $\begin{array}{l}\text { No reliable estimates } \\
\text { Circa 1.8-2 kt PVC } \\
\text { waste from flooring in- } \\
\text { stallation }\end{array}$ & $\begin{array}{l}\text { Installation waste from floor- } \\
\text { ing collected by The Swedish } \\
\text { Flooring Trade Association: } \\
325 \text { tonnes per year, mostly } \\
\text { PVC. Collection of pipes by } \\
\text { The Nordic Pipe Association: } \\
\text { around } 100 \text { tonnes per year, } \\
\text { roughly } 30 \% \text { PVC. } \\
\text { Collection on a B2B-level may } \\
\text { exist }\end{array}$ & $\begin{array}{l}\text { Flooring installation waste from } \\
\text { Tarkett collected within The Swedish } \\
\text { Flooring Association is recycled in } \\
\text { Ronneby. Pipe waste collected within } \\
\text { The Nordic Pipe Association is recy- } \\
\text { cled abroad. Other PVC waste from } \\
\text { C\&DW is generally recovered for en- } \\
\text { ergy within mixed waste fractions }\end{array}$ \\
\hline WEEE and cables & No reliable estimates & $\begin{array}{l}\text { The amount of PVC in col- } \\
\text { lected WEEE and cables are } \\
\text { not known. }\end{array}$ & $\begin{array}{l}\text { PVC in cable waste either goes to re- } \\
\text { cycling or energy recovery/incinera- } \\
\text { tion }\end{array}$ \\
\hline ELVs & No reliable estimates & $\begin{array}{l}\text { 193,013 ELVs were collected } \\
\text { in 2017. A total of around } \\
3.1-5.2 \mathrm{kt} / \text { year of PVC in SLF. }\end{array}$ & $\begin{array}{l}\text { SLF goes to energy recovery or land- } \\
\text { fill. }\end{array}$ \\
\hline PVC from health care & No reliable estimates. & $\begin{array}{l}\text { No separate collection. PVC } \\
\text { waste ends up in mixed waste } \\
\text { fractions }\end{array}$ & $\begin{array}{l}\text { Energy recovery as hazardous or } \\
\text { non-hazardous waste }\end{array}$ \\
\hline Packaging & $\begin{array}{l}\text { Generation of PVC plas- } \\
\text { tic packaging waste is } \\
\text { unknown. }\end{array}$ & Unknown & $\begin{array}{l}\text { PVC in packaging waste is generally } \\
\text { sorted out as a reject fraction and } \\
\text { sent to energy recovery }\end{array}$ \\
\hline
\end{tabular}

Note: For data source, see the text above. 


\section{Leading examples in the EU}

\subsection{PVC waste in Germany}

In Germany, there is an industry network, AGPU that includes circa 60 members comprising the entire PVC value chain. AGPU is in turn a member of VinylPlus and other national and international associations. AGPU, together with these associations, commissions periodical updates on waste information, including generation and management of PVC waste. ${ }^{247}$

According to the latest available data from 2013, the total amount of generated PVC waste in Germany was circa 647,300 tonnes (up from 563,000 tonnes in 2007), which corresponds to around $1-2 \%$ of total household and similar waste. The share of post-consumer PVC is around $80 \%$. PVC present in mixed waste streams goes to incineration. Landfilling PVC waste is banned. ${ }^{248}$ About 37\% (243,000 tonnes) of all PVC waste is recycled mechanically and circa 140,000 tonnes of this are post-consumer waste. Closed-loop ("in-house") industrial recycling is not accounted for in these figures. ${ }^{249}$ The largest fraction of recycled PVC waste is window frames. In 2013, the recycling target of 800,000t for the European PVC industry set by VinylPlus for 2020 was reached by about a third by Germany alone. ${ }^{250}$

The PVC industry in Germany cooperates with Recovinyl (as a mediator between recyclers and converters). ${ }^{251}$

\subsubsection{Collection}

PVC waste in Germany is collected through various collection initiatives (mainly run by manufacturers and recyclers) dedicated to managing various PVC-containing products such as pipes, windows, door frames and flooring. The collected waste is recycled either on the sites of each system or brought to external recyclers. A number of initiatives are described below.

Some of the producers and recyclers have a take-back system for windows, roller shutters and doors made of plastic in Germany. Moreover, many of them have a close cooperation with their recycling partners. ${ }^{252}$

\footnotetext{
247 https://www.agpu.de/en/all-about-pvc/recycling

248 https://www.agpu.de/wp-content/uploads/2018/01/Argumentarium_en.pdf

249 https://www.agpu.de/en/all-about-pvc/recycling

250 https://www.agpu.de/wp-content/uploads/2018/01/Argumentarium_en.pdf

251 https://www.agpu.de/en/all-about-pvc/recycling

252 https://www.agpu.de/en/all-about-pvc/recycling
} 
Two German companies, Rohr-recycling in Westeregeln and Kunststoffrohnverband $(K R V)$, established an alliance to increase recycling of PVC pipes. The initiative takes back PVC pipes throughout Germany and arranges their recycling.

Another example is Arbeitsgemeinschaft PVC-Bodenbelag Recycling (AgPR) 253 (Association for PVC floor covering recycling), which collects post-consumer PVC floor coverings in Germany and some other countries in Europe. The recycled PVC mixed with different plasticizers and fillers is used in the production of coating membranes in new floor-coverings. ${ }^{254}$ The post-consumer floor material is collected at dedicated collection centres. These centres collect only post-consumer PVC floor coverings in accordance with the AgPR's acceptance conditions and recycling specifications. ${ }^{255}$

Another example is the European Single Ply Waterproofing Association (ESWA), which collects and recycles post-consumers PVC waste from the building sector. The association has established the so-called ROOFCOLLECT ${ }^{\circledR}$ system organizing the collection and recycling of waterproofing membranes in Germany and in other European countries. ${ }^{256}$ The system unites several producers of thermoplastic roofing and waterproofing membrane materials and under the umbrella of ESWA becomes a Europewide recycling solution for the customers of ESWA's members. ROOFCOLLECT ${ }^{\circledR}$ offers the complete logistics covering material picks-up from the construction/demolition sites and transportation to recycling facilities. The collected waste is handled by the recycling company Hoser, which produces new floor protection sheets for a variety of applications, such as greenhouse mats, lawn grid/paddock grid, riding arena mats, stable mats/box mats, riding arena mats, paddock fastening, including various products for roof protection.

Another example is the EPCOAT initiative (VinylPlus project) for collection and recycling of PVC-coated tarpaulins. ${ }^{257}$ The EPCOAT initiative is run by IVK, that represents the joint interests of European companies producing sheets made of plastic and rubber for a multitude of applications. IVK is also a member of VinylPlus. ${ }^{258}$

Another relevant initiative for other PVC waste, such as packaging, cables, credit cards and other mixed PVC waste, is provided by AGPU. It offers a matchmaking platform, PVC-Recycling-Finder, which facilitates finding a recycling company for different PVC waste streams (e.g. rigid PVC) and sellers of products made of recycled PVC. ${ }^{259}$

\footnotetext{
253 http://www.agpr.de/cms/website.php?id=/en/start.htm

254 http://agpr.de/cms/website.php?id=/en/recycling-endproduct.htm\&nid=1\&nidsub=4

255 http://agpr.de/cms/website.php?id=/en/recycling-process.htm\&nid=1\&nidsub=3

${ }^{256}$ http://www.roofcollect.com/index.cfm

257 https://www.agpu.de/en/all-about-pvc/recycling

${ }^{258}$ http://www.ivk-europe.com/ivkenglish/index.cfm/ivk/recycling/

259 https://www.pvcrecyclingfinder.de/en/pvc-recycling-finder/
} 


\subsubsection{Mechanical recycling}

The largest shares of both generated and recycled PVC waste originate from the construction sector. The most commonly recycled PVC waste is window profiles. The largest European PVC recycling plant is Veka-Umwelttechnik GmbH (Veka for short) located in Germany, which also has smaller plants in France and in the UK. ${ }^{260}$ In Germany, Veka's annual production capacity is circa 50,000 tonnes. The company recycles old windows, doors, roller shutters and profile offcuts and feeds them into the production of new profiles. ${ }^{261}$ Only $5-10 \%$ of the total feedstock for window profile manufacturing consists of recycled PVC to ensure the amounts of hazardous substances, such as cadmium, is below allowed levels. ${ }^{262}$ The main part of the recycled material $(80-90 \%)$ is used in the production of new window profiles, the rest for other products (e.g. pipes). The main challenge for the PVC recycling industry is technological - products become more complex and difficult to separate. For instance, different colours and the presence of composites, glues or glass makes the separation difficult. ${ }^{263}$

In Germany the main sources of PVC waste comes from about 1,500 window manufacturers, different disposal companies and Veka's take-back system (the company accepts old windows from their costumers of new PVC windows). ${ }^{264}$ In the UK, Veka collects old window profiles from construction/demolition sites where the company provides collection containers free of charge. ${ }^{265}$ In the Nordic region, two window manufacturers VENTISOL (Denmark) and a company in Finland (ESSUN) participate in Veka's take-back system, although the amounts are minor. ${ }^{266}$

In Germany, Veka is an active member of the VinylPlus and a member of a German initiative, Rewindo.

\subsubsection{Feedstock/chemical recycling}

There are some options for feedstock/chemical recycling of PVC waste. For instance, a plant at DOW/BSL in Schkopau is technologically suitable to accept PVC-rich waste streams in feedstock processes. PVC waste in both solid and liquid forms can be treated at this plant. Hydrogen chloride is separated during the thermal treatment with energy recovery. ${ }^{267}$

In another plant, Alzchem Trostberg GmbH in Hart, high calorific plastic fractions with a chlorine content of up to $10 \%$ can be used in the production of calcium carbide. Such waste materials are used to increase the amount and the calorific value of the resulting carbide furnace gas. Another company, Ecoloop, has a new technology for

\footnotetext{
260 https://www.veka.de/en/homepage/company/veka-and-recycling.html

${ }^{261}$ https://www.veka.de/en/homepage/company/veka-and-recycling.html

${ }^{262}$ Personal communication with representative of VEKA (the interviewee wants to remain anonymous).

263 Personal communication VEKA (the interviewee wants to remain anonymous).

264 https://www.veka-ut.de/index.php?id=49

265 http://www.veka-recycling.co.uk/services/

266 Personal communication with VEKA (the interviewee wants to remain anonymous)

267 https://www.agpu.de/en/all-about-pvc/recycling
} 
energy-efficient conversion of organic and carbon-rich waste materials (including PVC) into purified syngas as an energy source. In the process, raw materials with a chlorine content of up to $10 \%$ can be used. ${ }^{268}$

\subsubsection{Energy recovery}

Germany has currently 73 waste-to-energy plants for the treatment of municipal waste with an approved incineration capacity of circa 18 million tonnes per year. In 2013, energy recovery of PVC waste contributed to circa $30-35 \%$ of the total amount of chlorine input to the incineration plants, and it is assumed to be decreased by circa $50 \%$ compared to previous years. The decrease is partly attributed to increased recovery activities for PVC from packaging waste. ${ }^{269}$

The chlorine present in PVC waste during incineration is completely converted to $\mathrm{HCl}$ and removed from flue gases by scrubbers to levels that are far below the legally permitted emission limits. The scrubber liquid is neutralized with burnt lime. The resulting calcium chloride is landfilled. ${ }^{270}$ To reduce the chlorine input into incinerators, hydrogen chloride can be separated from the flue gas as hydrochloric acid and used again in chemical production. ${ }^{271}$

Some waste incineration plants do not use limestone scrubbers. For instance, five waste incinerators in Germany (located in Hamburg, Böblingen, Kiel, and in Kempten) use sodium hydroxide to neutralize the chlorine content and produce a valuable brine.

\subsubsection{Landfilling}

Since 2005 Germany has a ban on landfilling organic waste (wood, paper, and plastics). 272

\subsection{PVC waste in the Netherlands}

This part of the report is mainly based on a relatively old study (from 2011) and one interview with the PVC waste recycler, as there were no any other information sources available.

One of the biggest PVC pipes recycling companies in Europe, Van Werven is located in the Netherlands. Along with PVC pipes, other PVC waste fractions are also collected to be recycled (locally or exported) in the Netherlands.

\footnotetext{
${ }^{268}$ https://www.agpu.de/en/all-about-pvc/recycling

269 https://www.agpu.de/en/all-about-pvc/recycling

${ }^{270}$ https://www.agpu.de/en/all-about-pvc/recycling

${ }^{271}$ https://www.agpu.de/en/all-about-pvc/recycling

272 https://www.agpu.de/en/all-about-pvc/recycling
} 


\subsubsection{Collection}

Pipe manufacturers in the Netherlands have created a nation-wide pipe collection system (Buizen Inzamel Systeem, BIS). It offers take-back services for plastic pipe waste. Waste from PVC pipes are collected within BIS among other plastic pipes (PE and PP). On average about 1,300 tonnes of PVC waste pipes are collected annually, which are recycled by two companies - Morssinkhof Plastics BV and Kunststof Recycling De Hoeve BV. Some used pipes could also bypass the system and be delivered directly to recyclers who may pay more if large quantities of clean PVC pipes are delivered. There are several recyclers collecting PVC pipes from the Dutch market. Collectively they collect circa 3,700 tonnes of PVC pipes per year outside the BIS system. ${ }^{273}$ One of the largest recycling companies, Van Werven Plastic Recycling, collects circa 1,250 tonnes waste PVC pipes per year from the Dutch market.

The collection of windows and profiles is organised by the Plastic Facade Elements Industry Association (de Vereniging Kunststof Gevelelementenindustrie ,VKG), which has about 130 members representing the entire value chain of the plastics industry including suppliers, manufacturers of windows frames and sellers. In 2010, about 2100 tonnes of waste from window profiles and other PVC profiles were collected within the system. ${ }^{274}$ However, most of it is recycled abroad. ${ }^{275}$

Additionally, about 8,000 tonnes of PVC cable insulation waste are collected in the Netherlands. ${ }^{276}$

\subsubsection{Recycling}

The recycling of pipes and cables is rather well-established in the Netherlands, although it is handled by a relatively small number of large recyclers. ${ }^{277}$ In the report of TAUW $(2011)^{278}$ it was estimated that about 11450 tonnes of PVC waste were recycled in the Netherlands in 2010. Most of it (circa 80\%) was represented by recycling of pipes, the rest consisting of PVC windows and other profiles. As mentioned, Van Werven Plastic Recycling is the largest PVC pipe recycler. ${ }^{279}$ According to a recent interview with Van Werven they recycle around 12,000 tonnes of rigid post-consumer PVC waste per year collected mostly from the UK, the Netherlands, Belgium and Ireland. $95 \%$ consisted of pipes and profiles (other than window profiles) and the rest consisted of for example roof plates. PVC waste comes only occasionally in mono-fractions. The PVC pipe waste is commonly mixed with other plastic types. ${ }^{280}$

\footnotetext{
273 TAUW (2011). De keten van PVC. Van consumptie tot afval.

274 TAUW (2011). De keten van PVC. Van consumptie tot afval.

275 AJI-EUROPE (2006). The recycling of PVC waste in Europe (year 2004). https://vinylplus.eu/uploads/Modules/Documents/pvcrecycling2004.pdf

276 TAUW (2011). De keten van PVC. Van consumptie tot afval.

${ }^{277}$ AJI-EUROPE (2006). The recycling of PVC waste in Europe (year 2004). https://vinylplus.eu/uploads/Mo-

dules/Documents/pvcrecycling2004.pdf

${ }^{278}$ TAUW (2011). De keten van PVC. Van consumptie tot afval.

279 https://www.recyclingplastics.co.uk/contact

${ }^{280}$ Van Der Giessen, T (2018). Personal communication with Ton Van Der Giessen, CEO, Van Werven.
} 
The greenhouse and vegetable growing sector is rather large in the Netherlands. It uses large amounts of piping and water hoses, many of which are made of PVC. Discarded PVC hoses can be sent to Van Werven for recycling. Van Werven pays customers if PVC waste is not contaminated with other plastics. Otherwise customers pay Van Werven for waste handling and recycling. The company does not accept window profiles, since their management requires different processes and equipment (e.g. the removal of the glass and rubber strips). ${ }^{281}$

The PVC waste received by Van Werven is manually sorted to remove contaminants and is thereafter shredded, washed, grinded and de-metallized from non-ferrous and ferrous metals. Lower quality waste grades are sometimes also crushed with a hammer mill as an extra process step. The company has no difficulties to comply with the requirement for the maximum limit of $0.1 \%$ weight share of cadmium $(\mathrm{Cd})$ in the recycled PVC. Recycled PVC is tested twice a year, and the result is far below the limit. The limit value proposed by ECHA for lead $(\mathrm{Pb})$ in products produced from PVC recyclate is $1 \%$ weight share, which will probably not cause any problems for the company either. Currently the content of $\mathrm{Pb}$ in recyclate has not surpassed $0.8 \%$.

Van Werven faces a problem when exporting the recycled PVC to other countries. The Dutch Ministry of Environment has classified the recycled PVC as end-of-waste (EoW), which means that the material is treated as a product and not waste on the international market. ${ }^{282}$ Van Werven reached this EoW status in the Netherlands together with the Dutch government to remove obstacles for recycling in the Netherlands. This has been part of the North Sea Resources Roundabout (NSRR) Green deal. ${ }^{283}$ However, the EoW status of PVC recyclate does not pertain to other countries, where it could still be classified as "waste". The NSRR initiative currently investigates whether the Dutch EoW classification of PVC recyclate could have a comparable status in other participating countries. If approved, it could create a much larger playing field and new markets for recirculated PVC waste. ${ }^{284}$

\subsubsection{Energy recovery and landfilling}

PVC waste that remains in mixed waste streams (e.g. construction and demolition, hazardous and industrial waste) is mainly treated by energy recovery. It was, for instance, estimated that only about 4, 200 tonnes of PVC waste were landfilled in the Netherlands in 2010, while circa 123,000 tonnes of PVC waste from mixed waste streams were incinerated. ${ }^{285}$

\footnotetext{
${ }^{281}$ Van Der Giessen, T (2018). Personal communication with Ton Van Der Giessen, CEO, Van Werven.

${ }^{282}$ Van Der Giessen, T (2018). Personal communication with Ton Van Der Giessen, CEO, Van Werven.

${ }^{283}$ The North Sea Resources Roundabout (NSRR) is a collaboration between policy makers, inspectorates and industry representatives. It was initiated by six ministers from four North Sea countries (the UK, France, The Netherlands and Flanders). The involved stakeholders work together around specific issues, to identify and eliminate barriers related to cross-border trade, transportation including use of secondary materials. http://www.acceleratio.eu/challenging-rewarding-case-recycling-rigid-pvc/

284 http://www.acceleratio.eu/challenging-rewarding-case-recycling-rigid-pvc/

285 TAUW (2011). De keten van PVC. Van consumptie tot afval.
} 


\section{Discussion}

None of the Nordic countries have systematic statistics on the total generation of PVC waste. The available estimates are made occasionally, mostly within the frames of different projects and are not based on any formalized official reporting system or other rigorous accounting scheme.

Estimates on the total amount of PVC waste are difficult and prone to inaccuracies due to actual variations in the life expectancy of different PVC products as well as their estimates. Therefore, the stocks of PVC materials stored in form of various products are largely uncertain. For some products (e.g. pipes or window/door frames) it takes a few decades between products release on the market until they end up as waste. Some of the most widely used PVC-containing products, e.g. pipes, might never be collected as a separate waste category if they are left buried in the ground.

In theory, the generated amounts of PVC waste should equal the sum of the amounts recycled, energy-recovered and decommissioned either through landfilling and incineration without energy recovery, plus some amount of littering. The amounts of PVC waste material going to recycling are relatively easier to estimate as it is often a matter of accounting the separately collected clean PVC waste products or PVC-containing waste products collected with other types of plastic waste. However, when PVC waste materials are dispersed in mixed waste fractions the estimates are much less reliable and rarely based on waste composition analyses. The waste composition studies that are available, are usually not aimed at PVC materials but other plastics or other recyclable materials.

Some examples of different national estimates follow.

A soon to be published study by the Danish EPA estimates that over 66,000 tonnes of PVC waste are generated in Denmark annually representing roughly $11 \mathrm{~kg}$ per inhabitant. That estimate is higher than other available estimates made in previous studies for Denmark. In other countries (Finland, Norway and Sweden) the statistics on PVC waste generation rely mainly on expert estimates or old reports and indicate a much lower range than the Danish numbers (circa $5-5.5 \mathrm{~kg} / \mathrm{cap}$ in Finland, Norway and Sweden). Denmark is also the only country in the Nordic region that maintains statistics on how the separately collected PVC waste is treated. Taking the estimate of annual total PVC waste generation (circa $66 \mathrm{kt}$ ) recycling covers only circa $10 \%$ of this amount. However, the total estimate is not reliable due to poor data accuracy on the PVC share in mixed waste and other separately collected waste streams. For the Nordic countries other than Denmark, it is much harder to find reliable information on separate PVC collection and treatment. In Denmark the statistics of separately collected PVC waste and its treatment are part of the official Danish waste statistics, which is not the case in the 
other Nordic countries. One of the reasons could be that Finland, Norway ${ }^{286}$ and Sweden use European waste catalogue (EWC) which does not have dedicated categories for PVC waste. The categorization scheme used in EWC does not allow separate reporting of different types of plastics by origin, i.e. it is designed to report the general plastic waste from different sectors and not specific types of plastic waste. This means that even though PVC waste could be separately collected or treated, it may not be reflected in national statistics following the EWC.

There are no state-governed collection systems for PVC waste in Finland, Norway or Sweden, although private separate collection systems initiated by the flooring and piping industries exist. Some marginal scale business-to-business management systems for other PVC waste fractions, mostly pre-consumer PVC waste, are also in place. However, PVC waste is not a major business for private waste management companies and in general they are not much concerned with searching for PVC waste particularly. In Denmark, WUPPI offers a nation-wide collection system for rigid PVC waste from the construction sector engaging the producers and importers of rigid PVC products.

PVC waste materials from ELVs, health care, WEEE, cables and packaging in the Nordic countries are usually treated rather similarly. The larger parts of PVC waste, such as e.g. PVC from ELVs, are dismantled and stored (in Finland), but usually PVC materials end up as shredding light fraction (SLF) which goes either to energy recovery (in Sweden, Finland, Denmark and Norway) or landfilling (Denmark, Norway). Only in Norway is a small part of the SLF sent for recycling. To the projects' knowledge, PVC from health care are not recycled in any of the Nordic countries and its collection in mixed waste streams destined for energy recovery is common practice.

Diverse situations exist with PVC materials present in waste cables. In Norway cables are classified as part of WEEE, which means that the provisions of the national EPR legislation apply and a separate collection for cables exists. Finland has also recently introduced a similar EPR system for PVC cables, although it applies only to cables with electrical plugs. In the Nordic countries PVC in cables usually go to granulation and later to energy recovery or landfilling, but shares are largely unknown or estimates are not reliable. In Sweden, the recycling of PVC waste from cables is not specifically targeted and most of it is sent to energy recovery or storing (not landfilling). Nevertheless, according to estimates PVC from WEEE is rather small.

Regarding PVC in packaging, in Norway, Sweden and Denmark it could be collected within national EPR packaging systems and is generally sorted as a reject fraction and later sent to energy recovery. In Finland PVC-containing packaging is not accepted in the EPR system for packaging.

Overall, a larger part of PVC waste in Finland, Norway and Sweden generally ends up in mixed waste fractions and is treated in waste-to-energy plants. In Denmark, regulations require that PVC waste should be collected separately. Rigid PVC waste should be recycled and soft PVC disposed in landfills. However, in reality only around circa $10 \%$

\footnotetext{
${ }^{286}$ Norway has also local waste classification where PVC waste has its own category (code 1723), however, neither data on PVC waste collection nor treatment are available.
} 
of PVC is collected separately and the majority of it still ends up in waste-to energy plants together with other mixed waste streams.

According to the EU regulations ${ }^{287}$, homogenous streams of PVC waste, if it contains organic halogens exceeding $1 \%$ expressed as chlorine equivalents, must be thermally treated at incinerators reaching at least a temperature of $1100^{\circ} \mathrm{C}$ in order to avoid hazardous emissions of chlorine compounds. This is generally the case for homogenous PVC waste streams since they can contain up to $57 \%$ of chlorine and are classified as hazardous waste to be treated in hazardous waste incineration plants. However, when PVC materials end up in mixed waste streams, the equivalent share of chlorine is much lower and such waste can be subjected to regular thermal treatments.

The waste-to-energy sector is generally reluctant to accept mono-streams of PVC waste. The main reason is that chlorine compounds may cause corrosion in the flue gas cleaning system. This risk can be reduced by mixing PVC waste with other waste types. In addition, not all incinerating facilities can deal with higher quantities of PVC waste in mixed waste streams. For this reason, different exemption systems are practiced: e.g. an exemption from the landfilling ban for organic compounds in Finland and Sweden and an exemption from the landfilling ban for combustibles in Sweden. Landfilling permits (exemptions from bans) can be granted in Finland and Sweden if there is no capacity for recycling or energy recovery within reasonable transport distance.

In case of PVC waste, the exemptions are justified on the grounds that its environmental effects are considered negligible - PVC is non-biodegradable and regarded to be inert at landfill sites. Accurate statistics on how much PVC waste that is landfilled are not available, but according to some Swedish estimates the amounts are minor. In Finland only three local remote landfills have received temporary licenses to accept limited amounts of PVC waste. ${ }^{288}$ In Norway it is legal to landfill PVC waste, but as landfilling is often a more expensive option than the alternatives it is not carried out to a high extent.

PVC waste from demolition and rehabilitation, especially PVC flooring, is collected as hazardous waste in Norway and reported with the Norwegian waste code 7156 Waste with phthalates. In 2017, 4,500 tonnes of waste with phthalates were reported to the Norwegian EPA, most of that amount is assessed to be soft PVC flooring. As municipal waste collection plants have limited possibilities to check for possible phthalate content in the PVC waste from demolition and rehabilitation they receive, the rule of thumb is that this fraction is collected as hazardous waste.

Most of the recycling of PVC waste from all of the Nordic countries seems to occur abroad. Other than on-site recycling of pre-consumer PVC waste, no other significant local recycling capacities of PVC waste exist. Mainly clean pre-consumer waste from construction industry (e.g. pipes) is separately collected and sent for recycling abroad. The domestic recycling of PVC is limited largely by high costs (mainly collection and

\footnotetext{
${ }^{287}$ REGULATION (EU) No 1357/2014 of 18 December 2014 replacing Annex III to Directive 2008/98/EC of the European Parliament and of the Council on waste and repealing certain Directives.

${ }^{288}$ Personal communication with Vesa Kärhä, Finnish Plastic Industries Federation, 2018-06-07, 2018-06-14, 2018-08-15, 2018-08-21.
} 
dedicated logistics) and the inability to reach economies of scale. PVC waste is geographically dispersed in the Nordic region, which is the main factor inflating the costs of collection and transfer. Likewise, the costs of sorting, management and recycling are high while the market for recycled PVC waste is weak. ${ }^{289}$

None of the Nordic countries (except Denmark) have a specific focus on strategies or legislation on PVC waste issues. Compared to other Nordic countries, in Denmark PVC attracted more political debate since the 1990s, concerning incineration and hazardous substances in PVC materials. The political debates facilitated supporting legislation for a nationwide collection system for rigid and soft PVC waste through manned central collection sites. Different industry initiatives and the participation of producers and importers in systems such as VinylPlus, resulted in a nationwide separate collection of rigid PVC materials from the construction sector. The system is financed by producers, who also receive some financial support from VinylPlus. Although the issues surrounding an environmentally sound management of plastic waste is high on the political agenda in all Nordic countries, it is apparent that there is not much specific focus on PVC waste problems in Finland, Sweden or Norway.

Germany is among the leading countries in PVC waste recycling, being able to reach $37 \%$ of recycling for PVC in post-consumer waste. The Netherlands also recycle significant amounts of its PVC waste, which are mainly PVC pipes. In Germany and the Netherlands there exist several industry initiatives to collect and recycle various PVC waste streams. They cover many actors along the value chain including manufacturers, waste collectors, recyclers and users of recycled PVC products. Germany, with its high demand for plastics (one fourth of the EU demand) and high concentration of waste plastics (including PVC waste), is the main player in Europe driving forward plastics recycling in general and PVC recycling in particular. The variety of PVC recycling initiatives constitutes a sizeable recycling capacity in Europe, which today achieves one third of the 2020 recycling target for the European PVC industry set by the VinylPlus initiative.

\footnotetext{
${ }^{289}$ Pohjakallio M. \& Punkkinen H. (2018). Personal communication with Pohjakallio M. \& Punkkinen H., VTT.
} 


\section{Conclusions}

The current overview of PVC waste management in Denmark, Finland, Norway and Sweden yields mainly a rather fragmented picture, which is primarily based on information from interviews with experts. There are no systematic statistics on the total generation of PVC waste in neither of the Nordic countries. The available estimates are made occasionally, mostly within the frames or different projects and are not based on any formalized official reporting system or other rigorous accounting scheme.

Only Denmark collects official statistics specifically on the amounts of separately collected and treated PVC waste materials. A nation-wide dedicated collection system for PVC waste exists only in Denmark. Denmark also has a long history of national collection system for rigid PVC waste from the construction and demolition sector, which was established by producers and importers of PVC products.

In the other Nordic countries several separate collection systems for pre-consumer PVC waste (mainly business-to-business) exist initiated by business producing/importing flooring and piping products. The amounts of PVC waste collected in these collection systems are uncertain, but they are probably minor. In all studied countries most of the recycling of clean pre-consumer PVC waste takes place abroad. The exception is some smaller on-site recycling capacities for clean pre-consumer PVC waste, however they do not exist in the Nordic region. Overall, a larger part of PVC waste in Finland, Norway, Sweden and, to a smaller extent, in Denmark ends up in mixed waste fractions and is eventually treated in waste-to-energy plants. Landfilling of PVC waste is banned in two countries (Sweden and Finland), but some exceptions exist. In Norway it is legal to landfill PVC waste, but landfilling is usually a more expensive option. Norway is the only country that treats some PVC waste from the construction and demolition industry as hazardous waste. Denmark is the only country where soft PVC waste is legal to landfill.

The current waste treatment situation in the four Nordic countries is influenced by several factors. These factors inhibit economies of scale and higher rates of the collection and recycling of PVC waste in the region. Dispersed origins of PVC products and later waste, Nordic market specifics, low focus on PVC waste in the policy strategies or plans, technical issues regarding incineration of PVC waste, lack of domestics recycling capacities are among many other factors causing the current situation.

Denmark is the only country where PVC waste issues have some specific focus in national strategies and plans. According to the projects interviews, in the other Nordic countries, there do not seem to be any other particular plans to change the situation of PVC waste management. 
Germany is among the leading countries in PVC waste recycling. It recycles more than one third of all of its PVC waste (mainly windows and other profiles). The Netherlands also recycle significant amounts of its PVC waste, which are mainly PVC pipes. Both countries have large PVC manufacturing and recycling companies, which are part of the VinylPlus initiative. Together with other actors within PVC value chains they are organising separate collection of PVC materials. 


\section{Sammanfattning}

Nyckelord: Polyvinylklorid, PVC, PVC-avfall, plastavfall, plast, avfallsbehandling, Norden, Sverige, Danmark, Norge, Finland.

Polyvinylklorid (PVC) har på grund av lång livslängd och många goda mekaniska, elektriska och kemiska egenskaper samt god värme- och brandbeständighet, blivit den tredje mest använda plasten i Europa. Att uppnå de önskade egenskaperna hos PVC kräver tillsättning av olika tillsatser, av vilka vissa innehåller farliga ämnen som medför olika miljö- och hälsorisker. På grund av den omfattande användningen av PVC i samhället är PVC-avfallet en del av många avfallsflöden och är föremål för ett flertal olika behandlingar. Syftet med projektet är att kartlägga avfallsströmmar innehållande PVC i Danmark, Sverige, Norge och Finland och undersöka hur den nuvarande situationen ser ut. Resultaten och de viktigaste slutsatserna presenteras nedan.

\section{PVC satt på marknaden}

På grund av brist på produktionsdata för vissa länder har det inte varit möjligt att få fram tillförlitliga uppgifter om PVC och PVC-varor som satts på marknaden.

\section{Uppkomst av PVC-avfall i de nordiska länderna}

Översikten över avfallshantering av PVC i alla nordiska länder resulterade i en ganska delad bild baserad huvudsakligen på expertintervjuer. Det finns ingen systematisk statistik över den totala uppkomsten av PVC-avfall i någon av de nordiska länderna. De tillgängliga uppskattningarna tas fram oregelbundet och är ofta en del av olika projekt eller studier med olika mål. Ingen av de nordiska länderna utom Danmark har något formaliserat officiellt rapporteringssystem eller annat redovisningssystem.

Uppskattningar av uppkomsten av PVC-avfall i Norge, Finland och Sverige baseras huvudsakligen på gamla rapporter, experters utvärderingar eller extrapoleringar från europeiska genomsnittsdata. Det regionala genomsnittet per capita av uppkomsten av PVC ligger i intervallet 5-5,5 kg/capita. Denna uppskattning bör dock användas med försiktighet. Exempelvis uppskattades enligt de senaste uppgifterna från en rapport från Miljøstyrelsen (under utgivning) den totala årliga nationella utkomsten av PVC-avfall till 30 kton för mjuk och 36 kton för hård PVC (det vill säga 66 kton totalt) i Danmark. Detta motsvarar $11 \mathrm{~kg}$ per capita, vilket är dubbelt så mycket som den genomsnittliga uppskattningen. 


\section{Allmän hantering av PVC-avfall i de nordiska länderna}

Danmark är det enda landet i Norden som har statistik över hur det separat insamlade PVC-avfallet behandlas. Till exempel samlades 7000 ton in separat under 2017, 6825 ton ( $97,5 \%)$ skickades till återvinning, 169 ton $(2,4 \%)$ gick till deponering och 4 ton gick till energiåtervinning. Den mesta återvinningen av det separat insamlade PVC-avfallet sker utomlands. Med uppskattningen av den årliga totala uppkomsten av PVC (cirka 66 kton) skulle återvinningen endast gälla för ca $10 \%$ av denna mängd. Den totala uppskattningen av mängden är emellertid inte tillförlitlig på grund av osäkerheter i data för andelen PVC i blandat avfall och i andra separat insamlade avfallsströmmar.

Övriga nordiska länder har inga tillförlitliga uppgifter över hur avfallshantering av PVC fördelas mellan återvinning, energiåtervinning och deponering. Generellt för alla länder är att mycket PVC hamnar i blandade avfallsströmmar eller samlas ihop med andra separat insamlade avfallsströmmar, för vilka PVC inte är huvudmaterialet.

\section{PVC i bygg-och rivningsavfall}

Danmark har sedan länge ett nationellt insamlingssystem för hårt PVC-avfall från bygg- och rivningssektorn. Det startades av tillverkare och importörer av PVC-produkter. År 2017 samlades cirka 2000 ton in i systemet. Separat insamling vid kommunala återvinningscentraler finns också endast i Danmark. I övriga nordiska länder finns separata insamlingssystem för PVC-avfall i form av produktions- och installationsspill som initierats av företag som producerar/importerar golv och rörprodukter, men detta sker oftast företag emellan. Det är osäkert vilka mängder av PVC-avfall som samlas in genom dessa insamlingssystem.

PVC-avfall från rivning och renovering, huvudsakligen PVC-golv, samlas in som farligt avfall i Norge. År 2017 rapporterades 4500 ton avfall med ftalater in till Miljødirektoratet i Norge. Den största delen av denna mängd bedöms vara mjukt PVC-golv.

PVC som hamnar i andra separat insamlade avfallsströmmar, såsom uttjänta fordon, hälsovård, elektriska och elektroniska produkter, kablar och förpackningar i de nordiska länderna behandlas vanligen på liknande sätt. 


\section{PVC $i$ avfall ifrån uttjänta fordon}

Den största mängden av PVC-avfall i uttjänta fordon demonteras och lagras (i Finland), och mycket av detta PVC-material blir slutligen till fluff eller Shredder Ligh Fraction $(\mathrm{SLF})^{290}$. Fluff går vanligtvis till energiåtervinning (i Sverige, Finland, Danmark och Norge) eller deponering (Danmark, Norge). En del fluff i Norge skickas till materialåtervinning. Projektgruppen uppskattade att 1-5 kton PVC teoretiskt sett kan ingå i flufffraktioner (1-2 kton i Finland, 2-3 kton i Danmark, 3-5 kton i Sverige och ca 3 kton i Norge).

\section{PVC i hälso- och sjukvårdsavfall}

PVC från hälso- och sjukvården återvinns inte i någon av de nordiska länderna. Det samlas antingen in separat som farligt avfall eller i blandade avfallsströmmar. I båda fallen går detta PVC-avfall till energiåtervinning.

\section{PVC i kablar och elektriska och elektroniska produkter}

I de nordiska länderna finns inget specifikt fokus på PVC i kablar. Detta material brukar gå till granulering och sedan till energiåtervinning eller deponering, men hur mycket som går till de olika behandlingarna är okänt.

\section{PVC i förpackning}

Förpackningar innehållande PVC kan i Norge, Sverige och Danmark samlas in genom nationella system för producentansvar och sorteras vanligen ut som en rejektfraktion för att sedan skickas till energiåtervinning. I Finland är förpackningar innehållande PVC inte godkända att samlas in genom producentansvaret och dessa förpackningar hamnar sannolikt i det blandade avfallet för att sedan gå till energiåtervinning.

\section{Allmän behandling av PVC-avfall}

I alla nordiska länder sker återvinning av rent PVC-avfall i form av produktions- och installationsspill (främst från byggsektorn) utomlands. Undantaget är återvinning av eget produktionsspill på plats i mindre skala men det finns ingen tillförlitlig information om de återvunna mängderna. Enligt uppskattningar i projektet uppgår mängden återvunnet

${ }^{290}$ https://eldan-recycling.com/sv/\% $\mathrm{C}_{3} \% \mathrm{~A}_{5}$ tervinning-av-slf-shredder-light-fraction 
PVC-avfall i Norden till små mängder. Huvuddelen av PVC-avfallet i Finland, Norge, Sverige och, i mindre utsträckning, Danmark hamnar i blandade avfallsströmmar och behandlas i förbränningsanläggningar. Deponering av PVC-avfall är förbjudet i Sverige och Finland, med några undantag. I Norge är det lagligt att deponera PVC-avfall, men detta är vanligen ett dyrare alternativ. Norge är det enda landet som behandlar visst PVC-avfall från bygg- och rivningsindustrin som farligt avfall. Danmark är det enda land där deponering av mjukt separat insamlat PVC-avfall är lagligt. Uppgifter om fördelningen mellan förbränning och deponering är osäkra, men deponering sker i liten utsträckning.

\section{Skäl till nuvarande status och framtida planer}

Den nuvarande avfallsbehandlingen påverkas av flera faktorer som hämmar insamling och återvinning i större utsträckning av PVC-avfall. En aspekt är att PVC återfinns i många olika produktgrupper, som hanteras av olika insamlingssystem. De specifika förhållandena på den nordiska marknaden påverkar också PVC-avfallsbehandlingen. Den nordiska marknaden har en hög geografisk spridning av regioner, lågbefolkade områden och låg konsumtion av vissa i hög utsträckning återvinningsbara PVC-produkter (t.ex. PVC-fönsterramar). Av dessa anledningar utgör insamling av PVC-avfall inte ett stort affärsområde för många privata företag.

Ingen av de nordiska länderna, förutom Danmark, har någon specifik strategi eller lagstiftning kring PVC-avfall. Jämfört med de andra nordiska länderna har PVC fått ett större utrymme i den politiska debatten i Danmark när det gäller förbränning och farliga ämnen i PVC-material. Den politiska debatten underlättade en lagstiftning för ett rikstäckande insamlingssystem för hårt och mjukt PVC-avfall genom bemannade centrala insamlingsplatser. Olika branschinitiativ och producenters och importörers deltagande i system, såsom VinylPlus, resulterade i uppkomsten av rikstäckande separat insamling av hårda PVC-material från byggsektorn. Systemet finansieras av producenter, som också tar emot en del ekonomiskt stöd från VinylPlus.

Deponeringsförbud för organiskt och brännbart avfall i Finland och Sverige och höga kostnader för deponering är bland de främsta orsakerna till att mindre PVC-avfall går till deponering och att det mesta energiåtervinns genom förbränning. Danmark är det enda landet där mjukt PVC-avfall lagligt får deponeras, men även här är deponeringen liten.

Den största andelen PVC-avfall går till förbränning som blandat avfall, vilket kan innebära tekniska problem, såsom korrosion av rökgasreningssystemen i förbränningsanläggningar. För att förhindra klorföreningar i rökgaserna ställs särskilda lagkrav på lägsta förbränningstemperatur (minimum $1000^{\circ} \mathrm{C}$ ). Brist på återvinningskapacitet kan ibland resultera i undantag från deponeringsförbud i Sverige och Finland. Det verkar dock finnas ett växande politiskt intresse i att hitta bättre lösningar för hanteringen av PVC-avfall.

I Danmark har en nationell strategi för cirkulär ekonomi nyligen publicerats där PVC nämns i den politiska överenskommelsen om gemensam strategi/åtgärder inom kemikalieområdet och där 4 miljoner DKK är avsedda för åtgärder avseende farliga ämnen i PVC och substitution för andra material. Som en åtgärd har en kartläggning av PVC i Danmark ("Mapping of PVC in Denmark") gjorts, vars resultat kommer att användas för 
att definiera behovet av ytterligare studier för att definiera en dansk PVC-strategi. PVC har också fått ett särskilt fokus i den danska kemikaliehandlingsplanen (2018-2021). Enligt intervjuer $i$ andra nordiska länder verkar det inte finnas några andra planer på att förändra situationen för PVC-avfallshantering. Den 1 november 2018 kommer ett av de största PVC-återvinningsbolagen Van Warven att starta verksamhet i Borås (Sverige), där de kommer att etablera en manuell sorteringslinje för PVC-plastavfall som ska skickas till Nederländerna för återvinning.

\section{Översikt över Tyskland och Nederländerna}

Tyskland är bland de ledande länderna inom PVC-återvinning och kan nå en återvinningsgrad på 37 \% för PVC avseende konsumtionsavfall. Med denna återvinningsnivå uppnåddes redan 2013 en tredjedel av 2020-målet för materialåtervinning inom den europeiska PVC-industrin som fastställts av VinylPlus-initiativet. Huvuddelen av det separat insamlade PVC-avfallet som materialåtervinns är fönsterramar och andra PVC-profiler. Övriga PVC-produkter hamnar i blandade avfallsströmmar och går till energiåtervinning.

Även Nederländerna materialåtervinner betydande mängder PVC-avfall, huvudsakligen PVC-rör. Båda länderna har stora PVC-tillverknings- och återvinningsföretag, som ingår i VinylPlus-initiativet. Tillsammans med andra aktörer inom PVC-värdekedjan organiserar de separat insamling av PVC-material. 


\section{Appendix 1: PVC fees in Denmark}

Table 10: PVC fees for different products comprised of flexible PVC.

\begin{tabular}{|c|c|c|c|c|}
\hline \multirow{2}{*}{$\begin{array}{l}\text { Afgiftssatser } \\
\text { Varer indeholdende blød pvc }\end{array}$} & \multicolumn{2}{|c|}{2018} & \multicolumn{2}{|c|}{2019} \\
\hline & $\begin{array}{l}\text { Afgift ved } \\
\text { indhold af } \\
\text { ftalater }\end{array}$ & $\begin{array}{l}\text { Reduceret af- } \\
\text { gift ved anden } \\
\text { blødgører end } \\
\text { ftalater }\end{array}$ & $\begin{array}{l}\text { Afgift ved } \\
\text { indhold af } \\
\text { ftalater }\end{array}$ & $\begin{array}{l}\text { Reduceret af- } \\
\text { gift ved anden } \\
\text { blødgører end } \\
\text { ftalater }\end{array}$ \\
\hline Bløde rør og slanger & $3,50 \mathrm{kr} . / \mathrm{kg}$ & $1,40 \mathrm{kr} \cdot / \mathrm{kg}$ & $3,50 \mathrm{kr} . / \mathrm{kg}$ & $1,40 \mathrm{kr} . / \mathrm{kg}$ \\
\hline $\begin{array}{l}\text { Gulv- og vægbelægninger fremstillet af støtte- } \\
\text { materiale, imprægneret, overtrukket eller lami- } \\
\text { neret med pvc }\end{array}$ & $0,30 \mathrm{kr} . / \mathrm{kg}$ & $0,16 \mathrm{kr} . / \mathrm{kg}$ & $0,30 \mathrm{kr} . / \mathrm{kg}$ & $0,16 \mathrm{kr} . / \mathrm{kg}$ \\
\hline $\begin{array}{l}\text { Anden gulvbelægningsmateriale, vægbeklæd- } \\
\text { ning og loftsbeklædning }\end{array}$ & $0,30 \mathrm{kr} . / \mathrm{kg}$ & $0,16 \mathrm{kr} . / \mathrm{kg}$ & $0,30 \mathrm{kr} . / \mathrm{kg}$ & $0,16 \mathrm{kr} . / \mathrm{kg}$ \\
\hline Korkfliser & $0,30 \mathrm{kr} . / \mathrm{kg}$ & $0,16 \mathrm{kr} . / \mathrm{kg}$ & $0,30 \mathrm{kr} . / \mathrm{kg}$ & $0,16 \mathrm{kr} . / \mathrm{kg}$ \\
\hline Tape og selvklæbende folier blødgjorte & $3,50 \mathrm{kr} . / \mathrm{kg}$ & $1,40 \mathrm{kr} . / \mathrm{kg}$ & $3,50 \mathrm{kr} . / \mathrm{kg}$ & $1,40 \mathrm{kr} . / \mathrm{kg}$ \\
\hline Tape, ikke-blødgjort & - & $2,00 \mathrm{kr} . / \mathrm{kg}$ & - & $2,00 \mathrm{kr} . / \mathrm{kg}$ \\
\hline Tagfolier, blødgjorte & $3,50 \mathrm{kr} . / \mathrm{kg}$ & $1,40 \mathrm{kr} . / \mathrm{kg}$ & $3,50 \mathrm{kr} . / \mathrm{kg}$ & $1,40 \mathrm{kr} . / \mathrm{kg}$ \\
\hline Membranfolier, blødgjorte & $3,50 \mathrm{kr} . / \mathrm{kg}$ & $1,40 \mathrm{kr} . / \mathrm{kg}$ & $3,50 \mathrm{kr} . / \mathrm{kg}$ & $1,40 \mathrm{kr} . / \mathrm{kg}$ \\
\hline Tagplader, blødgjorte & $3,50 \mathrm{kr} . / \mathrm{kg}$ & $1,40 \mathrm{kr} . / \mathrm{kg}$ & $3,50 \mathrm{kr} . / \mathrm{kg}$ & $1,40 \mathrm{kr} . / \mathrm{kg}$ \\
\hline Ovenlysvinduer, blødgjorte & $3,50 \mathrm{kr} . / \mathrm{kg}$ & $1,40 \mathrm{kr} . / \mathrm{kg}$ & $3,50 \mathrm{kr} . / \mathrm{kg}$ & $1,40 \mathrm{kr} . / \mathrm{kg}$ \\
\hline Charteks og plastlommer & 0,05 kr./stk & 0,02 kr./stk & $0,05 \mathrm{kr} . / \mathrm{stk}$ & 0,02 kr./stk \\
\hline Tidsskriftskassetter & $0,33 \mathrm{kr} . / \mathrm{stk}$ & $0,13 \mathrm{kr} . / \mathrm{stk}$ & $0,33 \mathrm{kr} . / \mathrm{stk}$ & $0,13 \mathrm{kr} . / \mathrm{stk}$ \\
\hline Ringbind og brevordnere & $0,28 \mathrm{kr} . / \mathrm{stk}$ & $0,11 \mathrm{kr} . / \mathrm{stk}$ & $0,28 \mathrm{kr} . / \mathrm{stk}$ & $0,11 \mathrm{kr} . / \mathrm{stk}$ \\
\hline Handsker & $3,60 \mathrm{kr} . / \mathrm{kg}$ & $1,08 \mathrm{kr} . / \mathrm{kg}$ & $3,60 \mathrm{kr} \cdot / \mathrm{kg}$ & $1,08 \mathrm{kr} \cdot / \mathrm{kg}$ \\
\hline Forklæder & $3,60 \mathrm{kr} . / \mathrm{kg}$ & $1,08 \mathrm{kr} . / \mathrm{kg}$ & $3,60 \mathrm{kr} . / \mathrm{kg}$ & $1,08 \mathrm{kr} . / \mathrm{kg}$ \\
\hline Beskyttelsesdragter & $3,60 \mathrm{kr} . / \mathrm{kg}$ & $1,08 \mathrm{kr} . / \mathrm{kg}$ & $3,60 \mathrm{kr} . / \mathrm{kg}$ & $1,08 \mathrm{kr} . / \mathrm{kg}$ \\
\hline Regntøj & $3,60 \mathrm{kr} . / \mathrm{kg}$ & $1,08 \mathrm{kr} . / \mathrm{kg}$ & $3,60 \mathrm{kr} . / \mathrm{kg}$ & $1,08 \mathrm{kr} . / \mathrm{kg}$ \\
\hline Presenninger & $1,70 \mathrm{kr} . / \mathrm{m}^{2}$ & $0,42 \mathrm{kr} . / \mathrm{m}^{2}$ & $1,70 \mathrm{kr} . / \mathrm{m}^{2}$ & $0,42 \mathrm{kr} . / \mathrm{m}^{2}$ \\
\hline $\begin{array}{l}\text { Dækketøj, gardiner, rullegardiner, forhæng og } \\
\text { gardinkapper }\end{array}$ & $0,60 \mathrm{kr} . / \mathrm{kg}$ & $0,32 \mathrm{kr} . / \mathrm{kg}$ & $0,60 \mathrm{kr} . / \mathrm{kg}$ & $0,32 \mathrm{kr} . / \mathrm{kg}$ \\
\hline Kabler og ledninger & $2,48 \mathrm{kr} . / \mathrm{kg}$ & $0,91 \mathrm{kr} . / \mathrm{kg}$ & $2,48 \mathrm{kr} . / \mathrm{kg}$ & $0,91 \mathrm{kr} . / \mathrm{kg}$ \\
\hline Tagrender, stålplader og nedløbsrør & $0,25 \mathrm{kr} . / \mathrm{kg}$ & $0,10 \mathrm{kr} \cdot / \mathrm{kg}$ & $0,25 \mathrm{kr} \cdot / \mathrm{kg}$ & $0,10 \mathrm{kr} \cdot / \mathrm{kg}$ \\
\hline
\end{tabular}

Source Skatteministeriet (2017). http://www.skm.dk/skattetal/satser/satser-og-beloebsgraenser/pvcafgiftsloven 


\section{Appendix 2: Statistics - exports, imports and production of goods}

\section{Combined Nomenclature (CN)}

The Combined Nomenclature $(\mathrm{CN})$ is a tool for classifying goods, set up to meet the requirements both of the Common Customs Tariff and of the EU's external trade statistics. The $\mathrm{CN}$ is also used in intra-EU trade statistics. ${ }^{291}$ Also Norway uses the same classification (although they are not an EU member). There is data at different levels of detail (2, 4, 6 and 8-digit level), in which CN8 is the most detailed level. CN corresponds to the WCO's nomenclature Harmonised system (HS) at the 6-, 4- and 2-digit level. It was needed to use CN8 data to find relevant codes containing PVC.

\section{Sweden}

Every month Statistics Sweden publishes statistics on exports and imports of goods, which is value and quantity broken down by commodity and country. The survey on trade in goods with countries outside the EU (Extrastat) is based on information from Swedish Customs. The information originates in submitted import and export declarations regarding import of goods from or export of goods to a non-EU country. Since a declaration is required for all goods crossing Sweden's border for export to and import from a country outside the EU, no major inaccuracy is considered to exist.

Information about trade with EU countries (Intrastat) is collected via a total population survey with a cut-off limit, which means that the smallest enterprises are not included in the data collection. In addition to the submitted values, Statistics Sweden uses information from VAT declarations to the Swedish Tax Agency. Different model assumptions are made, in part for enterprises under obligation to provide information that have not reported values, in part for enterprises with trade that lies below the threshold value for obligation to provide information. At the total level, the level of accuracy is regarded as high, although inaccuracy exists at more detailed levels. ${ }^{292}$

\footnotetext{
${ }^{291}$ https://ec.europa.eu/taxation_customs/business/calculation-customs-duties/what-is-common-customstariff/combined-nomenclature_en

292 https://www.scb.se/contentassets/4584f3f1df19400a885428aaa914do6e/hao201_kd_2018_eng_ma_180222.pdf
} 


\section{Denmark}

The trade statistics in Denmark are also compiled on the basis of two general sources: Extrastat and Intrastat. Extrastat covers Denmark's trade in goods (imports and exports) with non-EU countries on the basis of the data on customs and supplies reported by business enterprises to the Danish tax authorities concerning their trade in goods with countries outside the EU.

Intrastat is the system behind the statistics of the trade of goods between Denmark and the other EU-countries. Intrastat is primarily based on monthly data reports submitted to Statistics Denmark by business enterprises in Denmark with regard to their trade in goods with enterprises in other EU countries. It is supplemented by information about EU trade derived from the VAT declarations that are filled out by all enterprises liable to pay VAT in Denmark. ${ }^{293}$

\section{Finland}

Data on trade by Finland with other EU Member States are collected from statistical declarations lodged by enterprises through the Intrastat system of internal trade. Information on the trade between Finland and non-EU countries is obtained from customs declarations, which shall be lodged on every import and export consignment. The data on internal and external trade are combined to form the International Trade Statistics. ${ }^{294}$

\section{Norway}

The statistics are mainly based on administrative information obtained from TVINN, which is the Norwegian Customs' electronic information system for the exchange of customs declarations between businesses and Norwegian Customs. Some data are however obtained from other sources. Sampling is not relevant as external trade is a total count of the goods defined in the population ${ }^{295}$.

\footnotetext{
293 https://www.dst.dk/en/Statistik/dokumentation/documentationofstatistics/international-trade-in-goods/statisticalprocessing

294 https://tulli.fi/en/statistics/statistics-specifications/foreign-trade-of-goods-by-enterprise-size-categories

295 https://www.ssb.no/en/utenriksokonomi/statistikker/muh/aar
} 


\section{Production of commodities (manufacturers' sales of goods)}

The statistics yearly present the breakdown of goods in industrial production with information on quantity and value according to the international classifications $\mathrm{CN}$ or Prodcom. Prodcom uses the product codes specified on the Prodcom List, which contains about 3900 different types of manufactured products. ${ }^{296}$

Products classified according to Prodcom are identified by an 8-digit code. The first four digits are the classification of the producing enterprise given by the Statistical Classification of Economic Activities in the European Community (NACE) and the first six correspond to the Classification of Products by Activity (CPA). The remaining digits specify the product in more detail. Most product codes correspond to one or more Combined Nomenclature (CN) codes, but some do not.

The data on production of commodities are collected through surveys in Sweden, Denmark, Finland and Norway.

\section{Non-response}

The statistics used on exports and imports of goods on a CN8-level are not always compensated for non-response. The non-response in the statistics of production of commodities is adjusted for in Sweden, Denmark and Finland. No statistics on industrial production in Norway have been used in this study due to no reported data and/or secrecy reasons.

\section{Coherence between trade statistics and production of commodities}

In this study, data from trade statistics is combined with data on production of commodities. In Sweden, the survey "Production of commodities and industrial services" is disseminated according to the same commodity nomenclature (CN) as foreign trade statistics, which to some extent enables coherence between exports, imports, and production information at the goods level. Although both surveys are based on the same nomenclature, there are differences that can make comparisons difficult. One difference between the surveys is that production of commodities and industrial services is an annual survey, while foreign trade in goods is a monthly survey. There are also differences in threshold values used to determine which enterprises are to be included in each data collection. Treatment of estimations for enterprises below the threshold is also different. Production of commodities and industrial services describes the value and the amount of goods, and associated services that the Swedish industry produced during the year, and according to economic theory there should be a connection between imports, production, consumption and exports. However, in practice, differences can be detected during joint checking of reported values. These differences can be explained by, for instance, that different CN8-codes have been used in the different

\footnotetext{
${ }^{296}$ https://ec.europa.eu/eurostat/statistics-explained/index.php/Industrial_production_statistics_introduced__PRODCOM\#How_are_PRODCOM_statistics_measured.3F
} 
surveys. Periodisation errors may also occur. These arise if the same goods have been reported in different periods in both surveys.

Also in Denmark exports and imports data are available according to the same commodity codes as manufacturer's sales (which corresponds to production of commodities statistics) so data can be combined. One difference between the two statistics is that the manufacturers sales of goods includes goods produced abroad under subcontracting for Danish enterprises, while the external trade statistics only includes goods that cross the Danish border. On the other hand, commercial resale turnover is divided on commodity codes in the external trade statistics, which is not the case in the manufacturer's sales statistics.

Norway and Finland use the commodity nomenclature (CN) only for foreign trade statistics. For the production of commodities, Norway and Finland use the Prodcom classification. To be able to compare data between countries and calculate the quantity of PVC that yearly is put on the market, products classified according to Prodcom have been converted to commodity nomenclature $(\mathrm{CN})$. This has been done for data on industrial production from Finland in this study. It has not been possible to use statistics on industrial production from Norway due to no reported data/secrecy reasons.

\section{Method}

\section{Selection of $\mathrm{CN}$-codes}

Statistics on foreign trade (exports and imports of goods) and production of commodities have been used. The first step was to identify and go through available $\mathrm{CN}$-codes in order to find product codes containing polyvinyl chloride. CN8 is the most detailed level and what has been used in the study.

Products codes containing the search words polyvinyl chloride or polymers of vinyl chloride were identified. It is sometimes hard to interpret the descriptions of the $\mathrm{CN}$ and Prodcom-codes and also to determine whether the product consists of merely PVC. Experts at SCB, IVL and the Swedish Customs helped to determine which codes should be selected for the purpose of this study. Some products contain not only PVC, which gives a risk for overestimation of the flows of PVC and therefore the results tables in this study show product codes containing only PVC separated from product codes possibly containing PVC and other substances.

On the other hand, using $\mathrm{CN}$-codes with PVC is an input product in many commodities which entails a risk for underestimation of the flows of PVC since this is not necessarily shown in the $\mathrm{CN}$-system. Using the search word polyvinyl chloride or polymers of vinyl chloride when identifying relevant $\mathrm{CN}$-codes also gives an underestimation as many products contain plastic (and possibly PVC), but they cannot be identified in an effective way with help of the CN-system. 
When studying $\mathrm{CN}$ - and Prodcom-data over several years it is important to check that the codes haven't been changed over the years. There have been no changes regarding the codes studied in this report between 2015 and 2016.

$\mathrm{CN}$ codes used in this analysis and its description are presented in Table 11.

Estimation of PVC put on the market

To get an indication of the quantity PVC put on the market ("inflow") in each county the following estimation is used:

Quantity put on the market $=$ imports + domestic production exports

A negative value indicates an actual outflow of the product, non-response, classifications errors or warehousing.

For some product flows data is not available. This could be due to lack of reported data, data is not available, data is too uncertain or of too bad quality, data has not been asked for or secrecy reasons.

In this study, the flows of PVC have been estimated for two years, 2015 and 2016. 2016 is the latest year available for the production of commodities statistics and hence the reason for not choosing 2016 and 2017.

In a few cases, the unit of the production of commodities is not tonnes or kilograms but another unit, for example square meters. To be able to make comparisons with trade statistics data, the quantity in tonnes of a certain commodity is estimated using the following formula: ${ }^{297}$

WeightPoc $\approx$ Weigth EXP $\times$ ValuePOC/ValveEXP

where

Weightpoc $=$ the weight specified in production of commodities (tonnes)

Weigth ${ }_{\mathrm{EXP}}=$ the weight specified in trade statistics, exports (tonnes)

Valuepoc $=$ the value specified in production of commodities (SEK/EUR etc)

Value EXP the value specified in trade statistics, exports (SEK/EUR etc.)

The reason for using the ratio of weight and value of exports and not imports is that the transportation cost is included in the imports data but not in the exports data. Using this estimation method makes it possible to obtain data of production of commodities in tonnes for all product codes regardless their original quantity unit.

\section{Secrecy issues}

Due to secrecy reasons, production data is not presented in the statistics for some $\mathrm{CN}$ codes. Hence, the quantities put on the market are probably higher than presented in the tables.

These figures include waste containing only PVC. The CN-code is 39153000 descripted as "Waste, parings and scrap, of polymers of vinyl chloride".

\footnotetext{
297 Sörme, Louise. \& Brolinson Hanna. (2010). PVC-golv och metodik för varuflöden. SCB. Chemitecs Report P4-D3a.
} 
Table 11: CN and PRODCOM codes used in the analysis and its description

\begin{tabular}{|c|c|c|}
\hline CN-codes 2015, 2016 & $\begin{array}{l}\text { PRODCOM-codes } \\
2015,2016\end{array}$ & Description CN \\
\hline 39041000 & 20163010 & Poly"vinyl chloride", in primary forms, not mixed with any other substances \\
\hline 39042100 & 20163023 & Non-plasticised poly"vinyl chloride", in primary forms, mixed with other substances \\
\hline 39042200 & 20163025 & Plasticised poly"vinyl chloride", in primary forms, mixed with other substances \\
\hline 39049000 & 20163090 & $\begin{array}{l}\text { Polymers of vinyl chloride or other halogenated olefins, in primary forms (excl. } \\
\text { poly"vinyl chloride", copolymers of vinyl chloride, polymers of vinyl chloride and fluor- } \\
\text { opolymers) }\end{array}$ \\
\hline 39153000 & - & Waste, parings and scrap, of polymers of vinyl chloride \\
\hline 39162000 & 22211070 & $\begin{array}{l}\text { Monofilament with any cross-sectional dimension of }>1 \mathrm{~mm} \text {, rods, sticks and profile } \\
\text { shapes, whether or not surface-worked but not otherwise worked, of polymers of vi- } \\
\text { nyl chloride }\end{array}$ \\
\hline 39172310 & 22212157 & $\begin{array}{l}\text { Rigid tubes, pipes and hoses, of polymers of vinyl chloride, seamless and of a length > } \\
\text { the maximum cross-sectional dimension, whether or not surface-worked, but not } \\
\text { otherwise worked }\end{array}$ \\
\hline 39172390 & 22212157 & $\begin{array}{l}\text { Rigid tubes, pipes and hoses, of polymers of vinyl chloride (excl. seamless and cut to } \\
\text { length only) }\end{array}$ \\
\hline 39181010 & 22231155 & $\begin{array}{l}\text { Floor coverings, whether or not self-adhesive, in rolls or in the form of tiles, and wall } \\
\text { or ceiling coverings "in rolls with a width of }>=45 \mathrm{~cm} \text {, consisting of a layer of plastics } \\
\text { fixed permanently on a backing of any material other than paper, the face side of } \\
\text { which is grained, embossed, coloured, design-printed or otherwise decorated", on a } \\
\text { support impregnated, coated or covered with poly"vinyl chloride" }\end{array}$ \\
\hline CN-codes 2015, 2016 & $\begin{array}{l}\text { PRODCOM-codes } \\
2015,2016\end{array}$ & Description CN \\
\hline 39181090 & 22231159 & $\begin{array}{l}\text { Floor coverings of polymers of vinyl chloride, whether or not self-adhesive, in rolls or } \\
\text { in the form of tiles (excl. those on a backing coated, impregnated or covered with } \\
\text { poly"vinyl chloride") }\end{array}$ \\
\hline 39191012 & 22292130 & $\begin{array}{l}\text { Plastic strips of poly"vinyl chloride" or of polyethylene, coated with unvulcanised nat- } \\
\text { ural or synthetic rubber, self-adhesive, in rolls }<=20 \mathrm{~cm} \text { wide }\end{array}$ \\
\hline 39204310 & 22213035 & $\begin{array}{l}\text { Plates, sheets, film, foil and strips, of non-cellular polymers of vinyl chloride, contain- } \\
\text { ing by weight }>=6 \% \text { of plasticisers, of a thickness of }<=1 \mathrm{~mm} \text {, not reinforced, lami- } \\
\text { nated, supported or similarly combined with other materials, without backing, un- } \\
\text { worked or merely surface-worked or merely cut into squares or rectangles (excl. self- } \\
\text { adhesive products, and floor, wall and ceiling coverings of heading 3918) }\end{array}$ \\
\hline
\end{tabular}

$\begin{array}{ll}\text { Polyvinyl chloride, not mixed with any other substances, in primary forms } & \text { yes } \\ \text { Non-plasticised polyvinyl chloride mixed with any other substance, in primary forms } & \text { no }\end{array}$

Non-plasticised polyvinyl chloride mixed with any other substance, in primary forms no

Plasticised polyvinyl chloride mixed with any other substance, in primary forms

Polymers of halogenated olefins, in primary forms, n.e.c. of polymers of vinyl chloride (including surface worked but not otherwise worked)

Rigid tubes, pipes and hoses of polymers of vinyl chloride

Rigid tubes, pipes and hoses of polymers of vinyl chloride

Floor coverings in rolls or in tiles and wall or ceiling coverings consisting of a support

impregnated, coated or covered with polyvinyl chlorid

Description PRODCOM

Other floor, wall, ceiling... coverings of polymers of vinyl chloride

Self-adhesive strips of plastic with a coating consisting of unvulcanised natural or syn- no thetic rubber, in rolls of a width $\leq 20 \mathrm{~cm}$

thetic rubber, in rolls of a width $\leq 20 \mathrm{~cm}$ $6 \%$ of plasticisers, thickness $\leq 1 \mathrm{~mm}$ 


\begin{tabular}{|c|c|c|c|c|}
\hline CN-codes 2015, 2016 & $\begin{array}{l}\text { PRODCOM-codes } \\
2015,2016\end{array}$ & Description CN & Description PRODCOM & $\begin{array}{l}\text { Only } \\
\text { PVC? }\end{array}$ \\
\hline 39204390 & 22213036 & $\begin{array}{l}\text { Plates, sheets, film, foil and strips, of non-cellular polymers of vinyl chloride, contain- } \\
\text { ing by weight }>=6 \% \text { of plasticisers, of a thickness of }>1 \mathrm{~mm} \text {, not reinforced, lami- } \\
\text { nated, supported or similarly combined with other materials, without backing, un- } \\
\text { worked or merely surface-worked or merely cut into squares or rectangles (excl. self- } \\
\text { adhesive products, and floor, wall and ceiling coverings of heading 3918) }\end{array}$ & $\begin{array}{l}\text { Other plates, sheets, film, foil and strips, of polymers of vinyl chloride, containing } \geq \\
6 \% \text { of plasticisers, thickness }>1 \mathrm{~mm}\end{array}$ & yes \\
\hline 39204910 & 22213037 & $\begin{array}{l}\text { Plates, sheets, film, foil and strips, of non-cellular polymers of vinyl chloride, contain- } \\
\text { ing by weight }<6 \% \text { of plasticisers, of a thickness of }<=1 \mathrm{~mm} \text {, not reinforced, lami- } \\
\text { nated, supported or similarly combined with other materials, without backing, un- } \\
\text { worked or merely surface-worked or merely cut into squares or rectangles (excl. self- } \\
\text { adhesive products, and floor, wall and ceiling coverings of heading 3918) }\end{array}$ & $\begin{array}{l}\text { Other plates, sheets, film, foil and strips, of polymers of vinyl chloride, containing < } \\
6 \% \text { of plasticisers, thickness } \leq 1 \mathrm{~mm}\end{array}$ & yes \\
\hline CN-codes 2015, 2016 & $\begin{array}{l}\text { PRODCOM-codes } \\
2015,2016\end{array}$ & Description CN & Description PRODCOM & $\begin{array}{l}\text { Only } \\
\text { PVC? }\end{array}$ \\
\hline 39204990 & 22213038 & $\begin{array}{l}\text { Plates, sheets, film, foil and strips, of non-cellular polymers of vinyl chloride, contain- } \\
\text { ing by weight }<6 \% \text { of plasticisers, of a thickness of }>1 \mathrm{~mm} \text {, not reinforced, laminated, } \\
\text { supported or similarly combined with other materials, without backing, unworked or } \\
\text { merely surface-worked or merely cut into squares or rectangles (excl. self-adhesive } \\
\text { products, and floor, wall and ceiling coverings of heading 3918) }\end{array}$ & $\begin{array}{l}\text { Other plates, sheets, film, foil and strips, of polymers of vinyl chloride, containing < } \\
6 \% \text { of plasticisers, thickness }>1 \mathrm{~mm}\end{array}$ & yes \\
\hline 39211200 & 22214130 & $\begin{array}{l}\text { Plates, sheets, film, foil and strips, of cellular polymers of vinyl chloride, unworked or } \\
\text { merely surface-worked or merely cut into squares or rectangles (excl. self-adhesive } \\
\text { products, floor, wall and ceiling coverings of heading } 3918 \text { and sterile surgical or den- } \\
\text { tal adhesion barriers of subheading 3006.10.30) }\end{array}$ & Plates, sheets, film, foil and strips of cellular polymers of vinyl chloride & yes \\
\hline 39232910 & 22221200 & Sacks and bags, incl. cones, of poly"vinyl chloride" & Plastic sacks and bags (including cones) (excluding of polymers of ethylene) & yes \\
\hline 59031010 & 13961400 & $\begin{array}{l}\text { Textile fabrics impregnated with poly"vinyl chloride" (excl. wallcoverings of textile } \\
\text { materials impregnated with poly"vinyl chloride") }\end{array}$ & Textile fabrics, impregnated, coated or covered n.e.c. & no \\
\hline 59031090 & 13961400 & $\begin{array}{l}\text { Textile fabrics coated, covered or laminated with poly"vinyl chloride" (excl. wallcover- } \\
\text { ings of textile materials covered with poly"vinyl chloride"; floor coverings consisting } \\
\text { of a textile backing and a top layer or covering of poly"vinyl chloride") }\end{array}$ & Textile fabrics, impregnated, coated or covered n.e.c. & no \\
\hline
\end{tabular}

CN c CN codes in English can be found here: http://www.cnwebb.scb.se/ and description of the codes can be found here: https://ec.europa.eu/eurostat/web/prodcom/data/excel-filesnace-rev.2odes in English can be found here: http://www.cnwebb.scb.se/ and description of the codes can be found here: https://ec.europa.eu/eurostat/web/prodcom/data/excel-filesnace-rev.2 


\section{Sverige}

Table 12: Product codes (CN) containing only PVC in 2015

\begin{tabular}{|c|c|c|c|c|}
\hline CN-code & Imports, tonnes & Exports, tonnes & Production, tonnes & PVC on the market \\
\hline \multicolumn{5}{|c|}{ Raw material (primary forms) } \\
\hline 39041000 & 59,554 & 222,176 & 226,205 & 63,583 \\
\hline Total raw material & 59,554 & 222,176 & 226,205 & 63,583 \\
\hline \multicolumn{5}{|c|}{ Goods with PVC (monofilament, tubes, pipes, hoses, floors, plates, sheets, strips, sacks etc.) } \\
\hline 39162000 & 509 & 1,851 & 4,680 & 3,338 \\
\hline 39172310 & 3,418 & 3,569 & 21,741 & 21,590 \\
\hline 39172390 & 1,479 & 312 & 1,134 & 2,301 \\
\hline 39181090 & 10,658 & 62,770 & $100,486 *$ & 48,374 * \\
\hline 39204310 & 1,718 & 6,600 & 6,462 & 1,580 \\
\hline 39204390 & 322 & 19 & 76 & 379 \\
\hline 39204910 & 1,611 & 245 & o & 1,366 \\
\hline 39204990 & 353 & 3,149 & 9,160 & 6,364 \\
\hline 39211200 & 1,694 & 2,539 & 5,190 & 4,345 \\
\hline 39232910 & 579 & 208 & $\circ$ & 371 \\
\hline Total goods & 22,341 & 81,262 & 148,929 & $90,008 *$ \\
\hline
\end{tabular}

Note: *Uncertain quality of production data for CN-code 39181090 .

Table 13: Product codes (CN) containing PVC + other substances in 2015

CN-code Imports, tonnes Exports, tonnes Production, tonnes PVC on the market

Raw material (primary forms)

\begin{tabular}{|c|c|c|c|c|}
\hline \\
\hline 39042100 & 3,691 & 2,892 & 7,617 & 8,416 \\
\hline 39042200 & 937 & 7,104 & 7,935 & 1,768 \\
\hline 39049000 & 146 & 57 & o & 89 \\
\hline Total raw material & 4,774 & 10,053 & 15,552 & 10,273 \\
\hline \multicolumn{5}{|c|}{ Goods with PVC (floors, strips, impregnated textile fabrics etc.) } \\
\hline 39181010 & 17,642 & 7,076 & o & 10,566 \\
\hline 39191012 & 1,659 & 293 & o & 1,366 \\
\hline 59031010 & 56 & 4 & 0 & 52 \\
\hline 59031090 & 713 & 138 & 221 & 796 \\
\hline Total goods & 20,070 & 7,511 & 221 & 12,780 \\
\hline
\end{tabular}

Table 14: Waste only including PVC (CN) in 2015 
Table 15: Product codes (CN) containing only PVC in 2016

\begin{tabular}{|c|c|c|c|c|}
\hline CN-code & Imports, tonnes & Exports, tonnes & Production, tonnes & PVC on the market \\
\hline \multicolumn{5}{|c|}{ Raw material (primary forms) } \\
\hline 39041000 & 65,237 & 208,209 & 210,858 & 67,886 \\
\hline Total raw material & 65,237 & 208,209 & 210,858 & 67,886 \\
\hline \multicolumn{5}{|c|}{ Goods with PVC (monofilament, tubes, pipes, hoses, floors, plates, sheets, foil and strips, sacks etc.) } \\
\hline 39162000 & 833 & 3,741 & 5,614 & 2,706 \\
\hline 39172310 & 2,819 & 3,775 & 20,805 & 19,849 \\
\hline 39172390 & 1,170 & 524 & 1,235 & 1,881 \\
\hline 39181090 & 13,899 & 57,309 & $89,110 *$ & $45,700 *$ \\
\hline 39204310 & 1,742 & 6,658 & 6,487 & 1,571 \\
\hline 39204390 & 284 & 76 & 129 & 337 \\
\hline 39204910 & 1,647 & 242 & 0 & 1,405 \\
\hline 39204990 & 486 & 2,788 & 5,144 & 2,842 \\
\hline 39211200 & 1,769 & 1,960 & 5,214 & 5,023 \\
\hline 39232910 & 570 & 125 & 1 & 446 \\
\hline Total goods & 25,219 & 77,198 & 133,739 & 81,760 \\
\hline
\end{tabular}

Note: *Bad quality of production data for $\mathrm{CN}$-code 39181090 .

Table 16: Product codes (CN) containing PVC + other substances in 2016

\begin{tabular}{|c|c|c|c|c|}
\hline CN-code & Imports, tonnes & Exports, tonnes & Production, tonnes & PVC on the market \\
\hline \multicolumn{5}{|c|}{ Raw material (primary forms) } \\
\hline 39042100 & 5,190 & 3,002 & 6,295 & 8,483 \\
\hline 39042200 & 844 & 7,164 & 8,909 & 2,589 \\
\hline 39049000 & 106 & 23 & 0 & 83 \\
\hline Total raw material & 6,140 & 10,189 & 15,204 & 11,155 \\
\hline \multicolumn{5}{|c|}{ Goods with PVC (floors, strips, impregnated textile fabrics etc.) } \\
\hline 39181010 & 17,717 & 8,104 & o & 9,613 \\
\hline 39191012 & 1,602 & 330 & 0 & 1,272 \\
\hline 59031010 & 39 & 6 & 0 & 33 \\
\hline 59031090 & 907 & 164 & 364 & 1,107 \\
\hline Total goods & 20,265 & 8,604 & 364 & 12,025 \\
\hline
\end{tabular}

Table 17: Waste only including PVC (CN) in 2016 


\section{Denmark}

Table 18: Product codes (CN) containing only PVC in 2015

\begin{tabular}{|c|c|c|c|c|}
\hline CN-code & Imports, tonnes & Exports, tonnes & Production, tonnes & PVC on the market \\
\hline \multicolumn{5}{|c|}{ Raw material (primary forms) } \\
\hline 39041000 & 27,344 & 1,979 & o & 25,365 \\
\hline Total raw material & 27,344 & 1,979 & 0 & 25,365 \\
\hline \multicolumn{5}{|c|}{ Goods with PVC (monofilament, tubes, pipes, hoses, floors, plates, sheets, foil and strips, sacks etc.) } \\
\hline 39162000 & 3,538 & 4,061 & 0 & -523 \\
\hline 39172310 & 2,630 & 1,856 & 4,953 & 5,727 \\
\hline 39172390 & 1,649 & 5,465 & 9,450 & 5,634 \\
\hline 39181090 & 2,516 & 195 & 0 & 2,322 \\
\hline 39204310 & 426 & 5,537 & 4,894 & -217 \\
\hline 39204390 & 393 & 141 & 1,981 & 2,233 \\
\hline 39204910 & 4,543 & 1,370 & 0 & 3,173 \\
\hline 39204990 & 1,826 & 409 & 366 & 1,784 \\
\hline 39211200 & 1,304 & 253 & 4 & 1,055 \\
\hline 39232910 & 940 & 203 & 0 & 737 \\
\hline Total goods & 19,765 & 19,490 & 21,648 & 21,925 \\
\hline
\end{tabular}

Table 19: Product codes (CN) containing PVC + other substances in 2015

\begin{tabular}{|c|c|c|c|c|}
\hline CN-code & Imports, tonnes & Exports, tonnes & Production, tonnes & PVC on the market \\
\hline \multicolumn{5}{|c|}{ Raw material (primary forms) } \\
\hline 39042100 & 5,272 & 687 & o & 4,585 \\
\hline 39042200 & 6,154 & 127 & o & 6,027 \\
\hline 39049000 & 606 & 234 & o & 372 \\
\hline Total raw material & 12,032 & 1,048 & 0 & 10,984 \\
\hline \multicolumn{5}{|c|}{ Goods with PVC (floors, strips, impregnated textile fabrics etc.) } \\
\hline 39181010 & 3,121 & 461 & o & 2,660 \\
\hline 39191012 & 1,411 & 772 & * & $639 *$ \\
\hline 59031010 & 294 & 10 & 0 & 284 \\
\hline 59031090 & 1,190 & 527 & 0 & 663 \\
\hline Total goods & 6,016 & 1,770 & * & $4,246 *$ \\
\hline
\end{tabular}

Note: *No production data due to secrecy reasons.

Table 20: Waste only including PVC (CN) in 2017

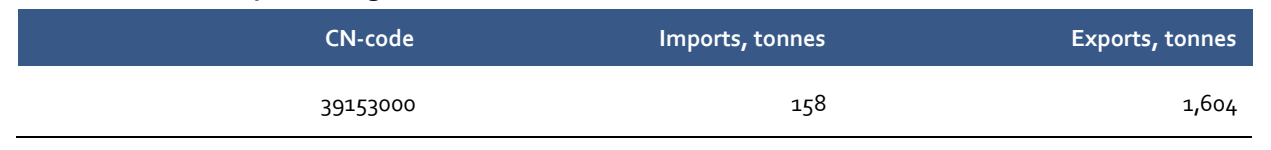


Table 21: Product codes (CN) containing only PVC in 2016

\begin{tabular}{|c|c|c|c|c|}
\hline CN-code & Imports, tonnes & Exports, tonnes & Production, tonnes & PVC on the market \\
\hline \multicolumn{5}{|c|}{ Raw material (primary forms) } \\
\hline 39041000 & 24,795 & 2,023 & o & 22,772 \\
\hline Total raw material & 24,795 & 2,023 & 0 & 22,772 \\
\hline \multicolumn{5}{|c|}{ Goods with PVC (monofilament, tubes, pipes, hoses, floors, plates, sheets, strips, sacks etc.) } \\
\hline 39162000 & 4,233 & 5,011 & o & -778 \\
\hline 39172310 & 4,104 & 1,593 & 5,843 & 8,353 \\
\hline 39172390 & 2,884 & 3,908 & 7,943 & 6,919 \\
\hline 39181090 & 2,508 & 67 & 0 & 2,441 \\
\hline 39204310 & 466 & 4,655 & 4,993 & 804 \\
\hline 39204390 & 380 & 137 & 1,252 & 1,495 \\
\hline 39204910 & 4,120 & 1,447 & 0 & 2,672 \\
\hline 39204990 & 1,971 & 432 & 340 & 1,880 \\
\hline 39211200 & 1,651 & 286 & 8 & 1,373 \\
\hline 39232910 & 1,032 & 93 & 0 & 939 \\
\hline Total goods & 23,349 & 17,629 & 20,379 & 26,098 \\
\hline
\end{tabular}

Table 22: Product codes (CN) containing PVC + other substances in 2016

$\begin{array}{lrrrr}\text { CN-code } & \text { Imports, tonnes } & \text { Exports, tonnes } & \text { Production, tonnes } & \text { PVC on the market } \\ & & & & \\ \text { Raw material (primary forms) } & & & 0 & 4,699 \\ 39042100 & 5,087 & 78 & 0 & 6,537 \\ 39042200 & 6,615 & 214 & 0 & 88 \\ 39049000 & 302 & 680 & 0 & 11,324 \\ \text { Total raw material } & 12,004 & & & \\ & & & 0 & 7,884 \\ \text { Goods with PVC (floors, strips, impregnated textile fabrics etc.) } & 510 & 1 & 609 \\ 39181010 & 8,394 & 821 & 0 & 288 \\ 39191012 & 1,429 & 44 & 0 & 530 \\ 59031010 & 331 & 485 & 1 & 9,311 \\ 59031090 & 1,015 & 1,860 & & \\ \text { Total goods } & 11,169 & & & \\ & & & & \\ & & & & \\ \end{array}$

Table 23: Waste only including PVC (CN) in 2016 
Norway

Table 24: Product codes (CN) containing only PVC in 2015

CN-code Imports, tonnes Exports, tonnes Production, tonnes PVC on the market

Raw material (primary forms)

\begin{tabular}{lrrrr}
39041000 & 6,147 & 0 & $*$ & $6,147^{*}$ \\
Total raw material & 6,147 & 0 & $*$ & $6,147^{*}$ \\
Goods with PVC (monofilament, sacks etc.) & & & & \\
39162000 & 2,619 & 35 & $*$ & $2,584^{*}$ \\
39232910 & 688 & 51 & $*$ & $637^{*}$ \\
Total goods & 3,307 & 86 & $3,221^{*}$ \\
\hline
\end{tabular}

Note: *No production data due to no reported data or secrecy reasons.

Table 25: . Product codes (CN) containing PVC + other substances in 2015

CN-code Imports, tonnes Exports, tonnes Production, tonnes PVC on the market

Raw material (primary forms)

\begin{tabular}{|c|c|c|c|c|}
\hline 39042100 & 268 & 0 & * & $268 *$ \\
\hline 39042200 & 3,002 & o & * & $3,002 *$ \\
\hline 39049000 & 61 & 4 & * & $57^{*}$ \\
\hline Total raw material & 3,331 & 4 & * & $3,327^{*}$ \\
\hline \multicolumn{5}{|c|}{ Goods with PVC (impregnated textile fabrics) } \\
\hline 59031010 & 40 & 2 & * & $39^{*}$ \\
\hline Total goods & 40 & 2 & * & $39^{*}$ \\
\hline
\end{tabular}

Note: *No production data due to no reported data or secrecy reasons.

Table 26: Waste only including PVC (CN) in 2015 
Table 27: Product codes (CN) containing only PVC in 2016

$\begin{array}{lrrrr}\text { CN-code } & \text { Imports, tonnes } & \text { Exports, tonnes } & \text { Production, tonnes } & \text { PVC on the market } \\ & & & & \\ \text { Raw material (primary forms) } & 6,260 & 0 & * & 6,260^{*} \\ 39041000 & 6,260 & 0 & & 6,260^{*} \\ \text { Total raw material } & & & * & 4,501^{*} \\ & 4,564 & 63 & * & 638^{*} \\ \text { Goods with PVC (monofilament, sacks etc.) } & 689 & 50 & & 5,139^{*} \\ 39162000 & 5,253 & 113 & & \\ 39232910 & & & \end{array}$

Note: *No production data due to no reported data or secrecy reasons.

Table 28: Product codes (CN) containing PVC + other substances in 2016

\begin{tabular}{l|l|l} 
CN-code & Imports, tonnes Exports, tonnes Production, tonnes PVC on the market
\end{tabular}

Raw material (primary forms)

\begin{tabular}{|c|c|c|c|c|}
\hline 39042100 & 737 & o & * & $737^{*}$ \\
\hline 39042200 & 2,296 & o & * & $2,296 *$ \\
\hline 39049000 & 21 & 2 & * & $20 *$ \\
\hline Total raw material & 3,054 & 2 & * & $3,053^{*}$ \\
\hline \multicolumn{5}{|c|}{ Goods with PVC (impregnated textile fabrics) } \\
\hline 59031010 & 25 & 2 & * & $23^{*}$ \\
\hline Total goods & 25 & 2 & * & $23 *$ \\
\hline
\end{tabular}

Note: *No production data due to no reported data or secrecy reasons.

Table 29: Waste only including PVC (CN) in 2016 


\section{Finland}

Table 30: Product codes (CN) containing only PVC in 2015

CN-code Imports, tonnes Exports, tonnes Production, tonnes PVC on the market

Raw material (primary forms)

$\begin{array}{llllr}39041000 & 19,974 & 49 & * & 19,926 * \\ \text { Total raw material } & 19,974 & 49 & * & 19,926 *\end{array}$

Goods with PVC (monofilament, tubes, pipes, hoses, floors, plates, sheets, strips, sacks etc.)

$\begin{array}{lrrrr}39162000 & 427 & 237 & 2,459 & 2,648 \\ 39172310,39172390 & 1,902 & 1,346 & 10,367 & 10,924 \\ 39181090 & & & & \\ 39204310 & 4,911 & 459 & 2,375 & 6,827 \\ 39204390 & 1,100 & 4 & 515 & 1,096^{*} \\ 39204910 & 973 & 236 & 87 & 1,252 \\ 39204990 & 585 & 7 & * & 664 \\ 39211200 & 868 & 39 & 281 & 829^{*} \\ 39232910^{* *} & 267 & 253 & 701 & 295 \\ \text { Total goods } & 150 & 2 & 16,785^{*} & 849 \\ & 11,183 & 2,583 & & 25,384^{*}\end{array}$

Note: *No production data due to no reported data or secrecy reasons.

**Not a 1-1 correspondence between $\mathrm{CN}$ and Prodcom-codes

Table 31: Product codes (CN) containing PVC + other substances in 2015

$\begin{array}{lrrrr}\text { CN-code } & \text { Imports, tonnes } & \text { Exports, tonnes } & \text { Production, tonnes } & \text { PVC on the market } \\ & & & & \\ \text { Raw material (primary forms) } & 192 & 2,136 & * & * / * * \\ 39042100 & 6,081 & 374 & * & 5,707^{*} \\ 39042200 & 17 & 7 & * & 10^{*} \\ 39049000 & 6,290 & 2,517 & & 5,717^{*} \\ \text { Total raw material } & & & * & \\ & 4,291 & 1,172 & 352 & 3,119^{*} \\ \text { Goods with PVC (floors, strips, impregnated textile fabrics etc.) } & 21 & 2,639 & 2,886 \\ 39181010 & 473 & 96 & 2,991^{*} & 6,809^{*} \\ 39191012 & 343 & 1,289 & & \end{array}$

Note: *No production data due to no reported data or secrecy reasons.

**Negative due to no production data/secrecy reasons.

***Not a 1-1 correspondence between $\mathrm{CN}$ and Prodcom-codes.

Table 32: Waste only including PVC (CN) in 2015 
Table 33: Product codes (CN) containing only PVC in 2016

\begin{tabular}{|c|c|c|c|c|}
\hline CN-code & Imports, tonnes & Exports, tonnes & Production, tonnes & PVC on the market \\
\hline \multicolumn{5}{|c|}{ Raw material (primary forms) } \\
\hline 39041000 & 22,755 & 13 & * & $22,743^{*}$ \\
\hline Total raw material & 22,755 & 13 & * & $22,743^{*}$ \\
\hline \multicolumn{5}{|c|}{ Goods with PVC (monofilament, tubes, pipes, hoses, floors, plates, sheets, strips, sacks etc.) } \\
\hline 39162000 & 386 & 222 & 3,020 & 3,185 \\
\hline 39172310,39172390 & 2,139 & 1,756 & 12,822 & 13,204 \\
\hline 39181090 & 6,250 & 625 & 2,797 & 8,422 \\
\hline 39204310 & 1,220 & 3 & * & $1,217^{*}$ \\
\hline 39204390 & 910 & 258 & 764 & 1,416 \\
\hline 39204910 & 657 & 11 & 94 & 740 \\
\hline 39204990 & 947 & 38 & * & $909^{*}$ \\
\hline 39211200 & 345 & 255 & 289 & 379 \\
\hline 39232910 ** & 76 & 0 & 686 & 762 \\
\hline Total goods & 12,930 & 3,168 & 20,472 * & $30,234^{*}$ \\
\hline
\end{tabular}

Note: *No production data due to no reported data or secrecy reasons.

**Not a 1-1 correspondence between CN and Prodcom-codes.

Table 34: Product codes (CN) containing PVC + other substances in 2016

\section{CN-code Imports, tonnes Exports, tonnes Production, tonnes PVC on the market}

Raw material (primary forms)

\begin{tabular}{|c|c|c|c|c|}
\hline 39042100 & 184 & 4,278 & * & $* / * *$ \\
\hline 39042200 & 6,476 & 409 & * & $6,066 *$ \\
\hline 39049000 & 16 & 4 & * & $12 *$ \\
\hline Total raw material & 6,676 & 4,691 & * & $6,078^{*}$ \\
\hline \multicolumn{5}{|c|}{ Goods with PVC (floors, strips, impregnated textile fabrics etc.) } \\
\hline 39181010 & 4,366 & 1,349 & * & $3,017^{*}$ \\
\hline 39191012 & 534 & 27 & * & $507^{*}$ \\
\hline $59031010,59031090 * * *$ & 377 & 110 & 2,548 & 2,814 \\
\hline Total goods & 5,277 & 1,486 & $2,548 *$ & $6,338 *$ \\
\hline
\end{tabular}

Note: *No production data due to no reported data or secrecy reasons.

**Negative due to no production data/secrecy reasons.

$* * *$ Not a 1-1 correspondence between $\mathrm{CN}$ and Prodcom-codes.

Table 35: Waste only including PVC (CN) in 2016

$$
\text { CN-code }
$$


Data sources

Imports and exports

Sweden http://www.scb.se/hitta-statistik/statistik-efter-amne/handel-medvaror-och-tjanster/utrikeshandel/utrikeshandel-med-varor/

Denmark http://www.statistikbanken.dk/10029

Finland http://tulli.fi/sv/statistik/tabeller http://uljas.tulli.fi/

Norway https://www.ssb.no/statbank/table/o88o1/?rxid=c0866613-8cf84140-ao18-f72ef6c3ebf 5

Production of commodities

Sweden http://www.scb.se/hitta-statistik/statistik-efter-amne/naringsverksamhet/naringslivets-struktur/industrins-varuproduktion-ivp/

Denmark https://www.statbank.dk/VARER1

Finland http://pxnet2.stat.fi/PXWeb/pxweb/sv/StatFin_Passiivi/StatFin_Passiivi_teo_tti/statfinpas_tti_pxt_001_201500.px/?rxid=75d473d74aa1-49dd-9c72-3045ea811fbg http://pxnet2.stat.fi/PXWeb/pxweb/sv/StatFin/Stat-

Fin_teo_tti/statfin_tti_pxt_001.px

Norway https://www.ssb.no/statbank/table/10455/?rxid=9ge8d5f1-492a4dac-a5ee-gf1fa5221a28 
Nordic Council of Ministers

Nordens Hus

Ved Stranden 18

DK-1061 Copenhagen K

www.norden.org

\section{PVC WASTE TREATMENT IN THE NORDIC COUNTRIES}

The aim of the project was to map PVC waste streams in Denmark, Sweden, Norway and Finland. The available estimates are made occasionally, mostly within the frames of different projects and are not based on any formalized official reporting system or other rigorous accounting scheme. Overall, a large part of PVC waste ends up in mixed waste fractions and is eventually treated in waste-to-energy plants. Landfilling of PVC waste is banned in two countries, but some exceptions exist. Norway is the only country that treats some PVC waste as hazardous waste. The current waste treatment situation in the four Nordic countries is driven by several factors, such as diverse origins of PVC products, some specifics of the Nordic market, rather low focus on PVC waste in policy strategies or plans, technical issues regarding incineration of PVC waste, and the lack of domestic recycling. 